\title{
Understanding Monetary Policy and its Effects: Evidence from Canadian Firms Using the Business Outlook Survey
}

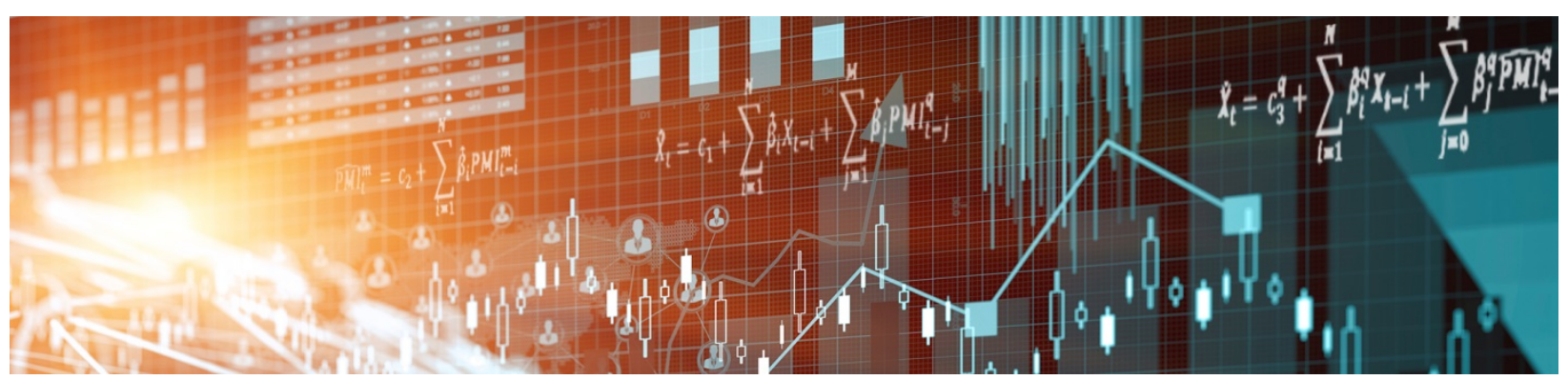

by Matthieu Verstraete and Lena Suchanek 
Bank of Canada Staff Working Paper 2017-24

June 2017

\title{
Understanding Monetary Policy and its Effects: Evidence from Canadian Firms Using the Business Outlook Survey
}

\author{
by \\ Matthieu Verstraete and Lena Suchanek \\ Canadian Economic Analysis Department \\ Bank of Canada \\ Ottawa, Ontario, Canada K1A OG9 \\ mverstraete@bankofcanada.ca
}




\section{Acknowledgements}

The authors are grateful to Yuriy Gorodnichenko for excellent ideas and discussions. We would like to thank Michael Ehrmann, Laurent Martin, Lise Pichette, Wei Dong, participants of the SCSE 2016 conference, the CEA 2016 conference, the 7th Annual Conference for Central Bank Business Surveys 2016 and a Bank of Canada seminar for helpful comments, and the Bank's projection team for help with the data. 


\begin{abstract}
This paper shows (i) that business sentiment, as captured by survey data, matters for monetary policy decisions in Canada, and (ii) how business perspectives are affected by monetary policy shocks. Measures of business sentiment (soft data) are shown to have systematic explanatory power for monetary policy decisions over and above typical Taylor rule variables. Stronger (weaker) survey results lead to higher (lower) policy rates over the period of study (2001-16). Moreover, we study the effects of monetary policy shocks on firms' business perspectives using data from the Bank of Canada's quarterly Business Outlook Survey. The monetary shocks are defined as the fitted residuals of the Taylor rule. Overall, the results are in agreement with the qualitative effects of monetary policy shocks described in the literature. For instance, an unanticipated tightening in monetary policy a year ago (or more) results in firms reporting tighter lending conditions today, as well as slower expected dynamics of future sales, wage growth and output prices. The results are qualitatively similar whether shocks are derived from a standard Taylor rule (hard data) or from an alternative Taylor rule (soft data).
\end{abstract}

Bank topics: Firm dynamics; Transmission of monetary policy; Interest rates

JEL codes: D22, E52, E44

\title{
Résumé
}

Nous montrons a) que la confiance des entreprises, telle qu'elle est captée par les données d'enquête, est une considération importante pour les décisions des autorités monétaires canadiennes et b) comment les perspectives des firmes sont influencées par les chocs de politique monétaire. Les résultats montrent que les indicateurs de la confiance des entreprises (données qualitatives) ont un pouvoir explicatif significatif, nonobstant l'inclusion des variables types de la règle de Taylor. Selon que le niveau de confiance révélé par les enquêtes soit élevé ou non, les résultats conduisent à un relèvement ou à un abaissement du taux directeur sur la période à l'étude (2001-2016). Nous étudions aussi les effets des chocs de politique monétaire sur les perspectives d'activité des entreprises en nous appuyant sur l'enquête trimestrielle de la Banque du Canada, Enquête sur les perspectives des entreprises. Les chocs monétaires correspondent aux résidus estimés de la règle de Taylor. Globalement, les résultats cadrent avec les effets qualitatifs des chocs de politique monétaire décrits dans la littérature. Par exemple, après un resserrement inattendu de la politique monétaire, les entreprises font état au bout d'un an (ou plus) d'un durcissement des conditions de prêt, ainsi que d'un ralentissement de la croissance future des ventes, des salaires et des prix des extrants. Ces résultats sont analogues sur le plan qualitatif, que les chocs soient tirés d'une règle classique de Taylor (données quantitatives) ou d'une règle de Taylor différente (données qualitatives).

Sujets : Dynamique des entreprises; Transmission de la politique monétaire; Taux d'intérêt Codes JEL : D22, E52, E44 


\section{Non-Technical Summary}

Central banks rely on a host of information sources when making monetary policy decisions, including, for instance, macroeconomic conditions and projections. A simple stylized description of how the central bank sets the interest rates is the Taylor rule (Taylor 1993). According to this rule, the nominal interest rate increases if (i) inflation rises above the central bank's inflation target, and (ii) the economy's actual output runs above its potential. ${ }^{1}$ The standard Taylor rule relies on quantitative data (i.e., hard data). While this rule is simple and intuitive, it is well understood that policy-makers consider a wider range of information than measures of inflation and the output gap (i.e. the difference between actual output and its potential).

In practice, the Bank of Canada also considers qualitative (or soft) data. For instance, the Governing Council takes into account insights from the Business Outlook Survey (BOS), a survey of a representative sample of Canadian businesses compiled by the Bank's five regional offices. In this research, we study the extent to which measures of business sentiment (such as the BOS or other business surveys) are reflected in the monetary policy stance, over and above quantitative sources of information. Concretely, we use the Taylor rule as the starting point for our study of monetary policy in Canada and modify it to incorporate survey data capturing business sentiment. Estimations are run in real time, i.e., with data available to policy-makers at the time of the interest rate decision. We show that business sentiment (soft data) helps significantly in understanding the Canadian monetary stance over and above typical Taylor rule variables (hard data). In particular, stronger survey results are associated with higher policy rates over the period of study (2001-16). The portion of the monetary stance that is left unexplained by either the soft or the hard data is defined as monetary policy shocks.

We then study the effects of a monetary policy shock on firms' business perspectives using data from the BOS. The questions included in the survey touch upon several key dimensions of a firm (e.g., sales, investments, prices) and thus allow us to study how different aspects of expected business activity change as a result of monetary policy shocks. We find that the effects of monetary policy shocks on firms are akin to the macroeconomic effects described in the literature; i.e., a monetary policy tightening tends to, with a lag, slow business activity and price pressures. For instance, an unanticipated tightening in monetary policy a year ago (or more) leads firms to see tighter lending conditions today. It also leads firms to expect slower dynamics for their future sales, wage growth and output prices. The results provide novel insight into the transmission of monetary policy using micro-level data or survey data, supporting the economic premises about the lagged and causal effect of monetary policy.

\footnotetext{
${ }^{1}$ Potential output can be defined as the level of output that can be sustained in an economy without adding to inflationary pressures.
} 
"The Business Outlook Survey...is an important complement to the other material that the [Monetary Policy Review Committee] and the Governing Council rely on and serves as a 'reality check' on regional economic developments."

John Murray, Bank of Canada Review, Autumn 2013

\section{Introduction}

The Taylor rule (Taylor 1993) is a simple, intuitive and stylized way to represent monetary policy. According to this rule, the overnight rate targeted by a central bank is positively related to (i) the difference between the actual rate of inflation and the inflation target, and (ii) the difference between the economy's actual output and its potential (i.e., the output gap). For example, the Taylor rule (henceforth TR) prescribes a central bank to raise the overnight interest rate when the inflation rate is above its target. While observers have documented that actual policy rates in many advanced economies have deviated importantly from the TR starting in the early 2000s (Taylor 2013), policy rates in Canada have remained relatively close to those predicted by a TR, and projection models at the Bank of Canada (the Bank) still use a TR to model the monetary policy reaction function (Gervais and Gosselin 2014; Dorich et al. 2013).

It is, moreover, well understood that central banks consider a broader set of variables and factors than those in the simple TR when deciding on the level of the policy rate. Yet, central bankers are sometimes perceived to rely only on hard data produced by statistical agencies (e.g., GDP numbers produced by Statistics Canada), and their complex models. In practice, policy-makers at the time of the interest rate decision also ponder soft data. For instance, the Bank considers, among various information sources, insights from the Business Outlook Survey (BOS), a survey of a representative sample of Canadian businesses compiled by the Bank's five regional offices (Murray 2013). Measures of business sentiment are a useful source of complementary information for monetary policy-makers because they provide reliable and timely measures of economic conditions (compared to hard data, which are published with lags and are often subject to large revisions).

In this paper, we first study the extent to which soft data, such as results from the BOS, affect monetary policy decisions in Canada. In particular, we estimate the TR using Canadian data on the rate of inflation and the output gap. The estimation is done using real-time data (Orphanides 2001) to mimic the information set available to the Bank's Governing Council when they set the overnight interest rate. 
The results agree with the aforementioned description of the TR. We then include survey data capturing Canadian business sentiment in the original, or standard, TR in order to test whether soft data matters for monetary policy decisions. The survey data used to capture business sentiment are taken from the BOS and from the business confidence survey (BCS) administered by the Conference Board of Canada. ${ }^{2}$ We find that monetary policy appears to have consistently responded to measures of business sentiment over and above its response to standard TR variables, with stronger (weaker) survey results leading to higher (lower) policy rates. Moreover, the output gap loses its explanatory power when we incorporate into the TR a measure of business sentiment derived from either survey, suggesting that business sentiment may simply be a better way than the output gap to measure current economic conditions in real time. We then compare the actual overnight rate set by the Governing Council to that predicted by the TR using real-time data, and we define the difference (i.e., the residual) between the two as a monetary policy shock. ${ }^{3}$

Second, we study the effects of standard and alternative monetary policy shocks on firms along a number of dimensions ranging from sales perspectives to credit conditions, as measured in the BOS. The BOS data are a natural choice for analyzing how monetary policy affects firms' business perspectives and, to a certain extent, the economy; survey variables have proven to be relatively well correlated with key macroeconomic variables such as GDP growth and investment. The period of study spans 2001 to 2016. Given the widely accepted premise that monetary policy affects the economy with a lag (Stock and Watson 2001; Christiano et al. 1999; Romer and Romer 2004), we define monetary policy shocks at lagged time horizons. Exogenous monetary policy shocks, which we define as a shock occurring before the measurement period of a firm outcome, provide support to the lagged and causal effect of monetary policy for nearly all major variables in the BOS. For instance, an unanticipated tightening of monetary policy more than a year ago translates into a slower expected growth rate of future sales. Overall, the results are in agreement with the qualitative effects of monetary policy shocks described in

\footnotetext{
${ }^{2}$ In particular, in the case of the BOS, business sentiment is derived from a principal component analysis of the survey results (Pichette 2012). In the case of the BCS, we use the Index of Business Confidence. We also experimented with a third survey of Canadian businesses, the Canadian Federation of Independent Business's (CFIB) Business Barometer, and obtained similar results (available upon request). However, one limitation of the CFIB's survey is that it targets only small and medium-sized firms.

${ }^{3}$ An advantage of using survey data is that it is not revised. This is in stark contrast with the output gap, which is fraught with uncertainty since it is unobservable and subject to measurement error (Pichette et al. 2015).
} 
the literature (Christiano et al. 1999), and with those of a simple bivariate structural vector autoregression (SVAR) that we estimate. ${ }^{4}$

The contributions to the literature are twofold. First, to our knowledge, this paper is the first to demonstrate empirically that survey data matter for monetary policy decisions, rejecting the perception that central bankers rely on hard data and complex models only. Our research therefore contributes to the literature on extensions of Taylor rules in a unique way (Ball 1999; Svensson 2000; Käfer 2014). The second innovation of the paper is that we shed light on the transmission of monetary policy using microlevel data or survey data. While several papers have used survey data on bank lending conditions to study the impact of a monetary policy shock on banks, ${ }^{5}$ research on the impact on firms is, at best, limited (Ehrmann 2004).

The rest of the paper is structured as follows: Section 2 describes the survey data used to capture business sentiment. Section 3 describes two different methods of estimating versions of the TR in real time and discusses results. Section 4 uses TR residuals as proxies of monetary policy shocks to study their impact on firms, as evidenced in the BOS, and looks at the robustness of these results. Finally, section 5 summarizes and concludes.

\section{The Survey Data}

This section introduces the survey data used in the analyses; a special emphasis is put on the BOS since it contains the data used to study the effects of monetary policy shocks at the firm level.

Since the autumn of 1997, the Bank's regional offices have conducted quarterly consultations with businesses across Canada. The BOS has provided the Bank with valuable and timely information and is a key input into the monetary policy process (Murray 2013). Information published in the BOS precedes national accounts data releases and therefore informs the monitoring of macroeconomic conditions in a timely manner. Moreover, the qualitative information helps refine the Bank's view on the economic outlook.

\footnotetext{
${ }^{4}$ As stated by Christiano et al. $(1999,69):$ “...after a contractionary monetary policy shock, ...aggregate output, employment...the aggregate price level responds very slowly, and various measures of wages fall...." See section 4.1 for a description of the bivariate SVAR that we estimate.

${ }^{5}$ See Kashyap and Stein (2000) for an example using US data, and Maddaloni and Peydró (2011) for an example with European data.
} 
The BOS is useful for studying the effects of monetary policy on the economy because it is informative in both macro and microeconomic contexts. Firm-level variables from the BOS, expressed as a balance of opinion, that is, the percentage of positive responses minus the percentage of negative responses, correlate reasonably well with their macroeconomic counterparts, with peak correlations often in lead quarters (Table 1). At the same time, the micro nature of the data provides us with the opportunity to estimate the effects of monetary policy shocks at the firm level.

Our analysis of the effects of monetary policy shocks on firm responses starts in 2001Q2 and ends in 2016Q1. The survey responses retained for analysis are the ones available throughout the sample and for which the definition did not change over time. ${ }^{6}$ The BOS sample is broadly representative of the Canadian business economy (i.e., it excludes the public sector).

To capture business sentiment we use a statistical summary measure of the information contained in the BOS, using principal component analysis. It includes the 10 survey questions published by the Bank in its quarterly publication of the BOS (Pichette and Robitaille 2017). ${ }^{7}$ The resulting summary measure is referred to as the BOS indicator and can be viewed as a more comprehensive measure of business sentiment than the selection of any individual BOS variable. ${ }^{8}$

The second measure of business sentiment we use is the Index of Business Confidence (IBC). The IBC is derived from the Conference Board of Canada's quarterly BCS in which 500 chief executive and chief financial officers of Canadian businesses are asked about their perceptions of the current economic environment and their investment intentions. ${ }^{9}$ The BCS sample is representative of Canadian business leaders. The advantage of the IBC over the BOS is that it has a longer history and thus allows us to start our analysis with the TR in 1993 rather than in 2001.10

\footnotetext{
${ }^{6}$ See Appendix A for more details on BOS variables.

${ }^{7}$ The survey questions are presented in Table 1. Their analysis excludes the question relating to firms' expectations regarding consumer price index inflation over the next two years since it does not pertain to firms' views on their own business situation or plans. For a previous version of the BOS indicator, see Pichette and Rennison (2011).

${ }^{8}$ The data are available on the Bank's web page. Using the BOS indicator avoids the piecemeal approach of fitting an alternative TR to each BOS variable, and then claiming that a particular variable is the "best" at capturing business sentiment based on the highest R-squared.

${ }^{9}$ The IBC is a composite indicator of three survey questions; see Appendix A.

10 The IBC is available from 1987Q1. Since the inflation-control target was adopted by the Bank and the Government of Canada in 1991 only, we start regressions in 1993 to avoid having to account for structural breaks in the monetary policy function.
} 
Using a second measure of business sentiment (i.e., the IBC) serves as a robustness check to evaluate whether it is the BOS itself, or business sentiment more generally, that matters for monetary policy. It also enable us to circumvent any potential endogeneity problems when we estimate a bivariate SVAR where a BOS variable, expressed as a balance of opinion, serves as the dependent variable in the first equation of the SVAR (section 4.1).

Neither the BOS nor the BCS data are revised.

\section{The Monetary Policy Rule}

First, this section reviews the literature in order to defend the choice of using a TR that (i) is forward-looking, (ii) includes an interest-smoothing term, (iii) uses real-time data, and (iv) tracks core rather than consumer price index (CPI) inflation. It next discusses the difference between Stark and Croushore's (2002) and Koenig et al.'s (2003) approaches to estimating a TR using real-time data, and establishes a preference for the latter. Finally, this section presents the results of estimating several TRs and provides evidence that the Governing Council takes soft data into account when setting monetary policy.

\subsection{Literature review on the Taylor rule and real-time estimation methods}

While the standard TR (Taylor 1993) uses the actual (lagged) rate of inflation, the subsequent literature has focused on forward-looking TRs because monetary policy affects output and inflation with a lag. ${ }^{11}$ The interest-rate-setting function should thus consider expected (or forecasts of) inflation. We estimate forward-looking TRs using the Bank's real-time two-quarters-ahead forecasts of inflation. Forward-looking TRs can be viewed as a robustness check of the results obtained with standard TRs.

The literature proposes versions of the TR that account for interest rate smoothing (e.g., Clarida et al. 1998, 1999 and 2000). More recently, Coibion and Gorodnichenko (2012) provide evidence for interest rate smoothing in explaining the federal funds rate. Our standard TR thus includes an interest rate smoothing term and is estimated using (i) actual data on lagged inflation (such as in Taylor 1993), and (ii) forecasts of inflation:

$$
i_{t}=c+\theta_{i} i_{t-1}+\theta_{\pi}\left(\pi_{t-1}-\pi^{*}\right)+\theta_{y} \hat{y}_{t}
$$

\footnotetext{
${ }^{11}$ A comprehensive overview of the design of forward-looking TRs is presented in Rudebusch and Svensson (1999), Batini and Haldane (1999), and Galí (2015), for instance.
} 


$$
i_{t}=c+\theta_{i} i_{t-1}+\theta_{\pi}\left(\hat{\pi}_{t+2}-\pi^{*}\right)+\theta_{y} \hat{y}_{t}
$$

where $i_{t}$ is the overnight rate (i.e., the Bank's key policy rate), $\hat{y}_{t}$ is the output gap, and the term $\left(\pi_{t-1}-\pi^{*}\right)$ denotes the difference between last quarter's inflation $\left(\pi_{t-1}\right)$ and the target inflation rate $\pi^{*}$ ( $\hat{\pi}_{t+2}$ denotes the two-quarters-ahead forecast of inflation). $\theta_{i}$ is the interest-rate-smoothing term. The parameters $\theta_{\pi}$ and $\theta_{y}$ are the sensitivities of the overnight rate to the deviation of inflation from the target and to the output gap, respectively.

In practice, central banks do not follow a TR in a mechanical way, but researchers consider it a useful approximation of the interest-rate-setting behaviour of central banks. Some researchers have augmented the TR with variables such as the exchange rate (Ball 1999; Svensson 2000; Markov and Nitschka 2013). We contribute to this literature by augmenting the TR with soft data, such as measures of business sentiment, extracted from surveys of Canadian businesses. For example, we include the BOS indicator in the standard TR (equation 3) and in the forward-looking TR (equation 4):

$$
\begin{aligned}
& i_{t}=c+\theta_{i} i_{t-1}+\theta_{\pi}\left(\pi_{t-1}-\pi^{*}\right)+\theta_{y} \hat{y}_{t}+\theta_{B O S} B O S_{t-1} \\
& i_{t}=c+\theta_{i} i_{t-1}+\theta_{\pi}\left(\hat{\pi}_{t+2}-\pi^{*}\right)+\theta_{y} \hat{y}_{t}+\theta_{B O S} B O S_{t-1} .
\end{aligned}
$$

We thus get a sense of the extent to which business sentiment, in this case captured by the BOS, systematically affects (or not) policy rate decisions in Canada, as measured by the coefficient $\Theta^{B O S}$. Note that we include the BOS indicator lagged by one quarter because the BOS is usually published during the first weeks following the quarter during which it was conducted (e.g., the BOS for 2016Q1, referred to as the spring survey, was published on April 1, 2016, i.e., in 2016Q2). The same is true for the IBC.

The literature has argued that policy decisions should be analyzed in real time or, in other words, using the information set that was available at the time the policy decision was made (Orphanides 2001; Croushore 2011). As is well known, data can be substantially revised from one release to the next and over subsequent releases. Thus, it is possible that policy-makers would have made different policy decisions had they been given access to the latest vintage of data. Statistically speaking, the parameter estimates of a TR might be very different depending on the vintage of data used for the estimation. We therefore estimate TRs using Canadian real-time data, i.e., nowcasts of the output gap as they appear in the Bank's past projection databases (Table 2). Similarly, whereas the standard backward-looking TR 
(equation 1) uses past inflation data that are not revised, when estimating forward-looking TRs, such as in equation 2, we rely on forecasts of inflation inherent in past vintages of the projection.

Both nowcasts of the output gap and forecasts of inflation in real time differ substantially from final or revised data. Measurements of the output gap are prone to revisions because potential GDP is difficult to estimate in real time (Pichette et al. 2015; Champagne et al. 2016; Tkacz 2010) and suffers from end-of-sample limitations. In addition, revisions to GDP imply important revisions to the output gap. As a result, the output gap is nearly impossible to pin down in real time (Croushore 2011; Orphanides and Van Norden 2002; see Cayen and Van Norden 2005 for evidence in the Canadian context). ${ }^{12}$ Considering projections at the Bank, the average revision of the output gap amounts to 0.8 per cent (in absolute terms-Table 3), with the largest corrections occurring during the Great Recession (2008Q3-2009Q2) (Chart 1). The mean error is positive (0.54 percentage points), meaning that the Bank's nowcasts of the output gap tend to overestimate GDP growth relative to its potential. However, it is relatively small given the volatility of the series (Table 3) and the fact that the sample period covers the Great Recession, a period during which the Bank consistently underestimated the excess supply.

Similarly, forecast errors of inflation are large (Table 3). Forecasts for core inflation, which excludes the most volatile components of the CPI (e.g., fruits, vegetables, gasoline, fuel oil, etc.) are subject to smaller forecast errors (Chart 2 and Table 3). ${ }^{13}$ To mimic the TR used in the projection models at the Bank, ${ }^{14}$ we use forecasts of core inflation when estimating forward-looking TRs (equations 2 and 4).

\footnotetext{
${ }^{12}$ Researchers have documented that revisions to the output gap in the United States may amount to more than 2 percentage points, a magnitude that is non-trivial from a policy perspective (Orphanides 2001). Kozicki (2004) provides measures of the policy implications of such revisions.

${ }^{13}$ Indeed, the average forecast error of core inflation is small (0.06 per cent), suggesting little bias in monitoring core inflation. While forecast errors are non-negligible in absolute terms-about 0.6 per cent, most of which is attributable to the recession (Table 3)-errors are much smaller than for total inflation (last column).

${ }^{14}$ The Bank of Canada's main target rate is indeed total inflation (target at 2 per cent). However, core inflation is used as an operational guide since it allows the Bank to "look through" temporary changes in total CPI inflation and to focus on the underlying trend of inflation. While the Bank has recently decided to replace the measurement of core inflation with three new measures (Bank of Canada 2016), this change does not affect our estimation since it spans a period (2001Q2-2016Q1) where only the previous measure of core inflation was used.
} 


\subsection{Comparing two approaches to estimating the Taylor rule in real time}

This section discusses two of the most common approaches to real-time estimation proposed by the literature, and defends our decision to use Koenig et al.'s (2003) approach for this paper rather than Stark and Croushore's (2002).

Real-time estimations of a TR à la Stark and Croushore (2002) amount to rolling regressions, gradually extending the period over which the equation is estimated. Each regression uses data on inflation and the output gap available at each point in time (i.e., each vintage of data produces one set of parameters for the TR). For example, using the vintage of data available in the second quarter of 2007 (e.g., second column of Table 2), the TR is estimated on data spanning 2001Q2 to 2007Q2. The TR is then estimated again using data available one quarter later (e.g., the third column of Table 2), spanning the 2001Q2-2007Q3 period, and so forth. ${ }^{15}$ Formally, this estimation is given by:

$$
\begin{array}{r}
i_{t}=c+\theta_{i, v} i_{t-1}+\theta_{\pi, v}\left(\pi_{t-1}-\pi^{*}\right)+\theta_{y, v} \hat{y}_{t, v} \\
v=2007 Q 2, \ldots, 2016 Q 1, t=2001 Q 2-2016 Q 1,
\end{array}
$$

where the subscripts $v$ refer to the vintage data as reported in time $v$, and $t$ refers to the time period. For instance, $\hat{y}_{t, v}$ refers to the output gap in quarter $t$ as estimated in vintage $v .{ }^{16}$ Equivalently, the forward-looking Taylor rule (equation 2) can be estimated in real time:

$$
\begin{gathered}
i_{t}=c+\theta_{i, v} i_{t-1}+\theta_{\pi, v}\left(\hat{\pi}_{t+2, v}-\pi^{*}\right)+\theta_{y, v} \hat{y}_{t, v} \\
v=2007 Q 2, \ldots, 2016 Q 1, t=2001 Q 2-2016 Q 1,
\end{gathered}
$$

where the inflation variable now also carries a vintage subscript since this regression relies on forecasts of inflation, which vary with each vintage. As discussed in the previous section, regression of equation 2.1 uses estimates of core inflation (rather than total inflation). We refer to these regressions as TR à la Stark and Croushore (2002)—henceforth SC.

${ }^{15}$ The starting point of the BOS indicator data used in the analysis is 2001Q1. The sample size increases in subsequent regressions up to the last regression using the latest-vintage data (i.e., 2016Q1).

${ }^{16}$ Inflation data do not get revised (only in seasonally adjusted terms). Hence, we do away with the $v$ subscript for inflation. Moreover, the coefficients on the BOS indicator do not carry vintage subscripts when added to the TR. (The same is true of the IBC.) In fact, although responses to questions of the BOS are never revised, the estimated coefficients of the BOS variables used to construct the BOS indicator do change slightly over time as new observations are added to the sample with each new wave of the survey. However, these revisions to the BOS indicator are very small and tend to get smaller as the sample of the BOS grows (Pichette and Robitaille 2017). 
While the approach proposed by SC is widely used in the literature, we believe it has some important drawbacks for our analysis. First, coefficients might change not only because of the changing importance of the output and inflation gaps in the policy function, but also simply because the sample size is so small to start with. ${ }^{17}$ Second, our objective is to use the residuals of TR estimations as monetary policy shocks. However, real-time estimations à la SC greatly reduce the number of available firm-level observations to study the effects of monetary policy shocks. ${ }^{18}$ Third, Koenig et al. (2003) argue that real time estimation should, for each date in the sample, use up-to-date estimates of explanatory variables available at that time ${ }^{19}$ which avoids the above issues altogether. For instance, when the dependent variable is the policy rate in 2011Q1, all right-side variables should be measured as they were estimated in 2011Q1. In the context of our research, real-time estimation of TRs à la Koenig et al. reduces to estimating one regression only (as opposed to rolling regressions à la SC), using the last diagonal of data shown in Table 2 (i.e., by using up-to-date estimates for the output gap available at each point in time of the sample). We refer to this methodology as real-time regressions à la Koenig et al.-henceforth KDP. This approach also corresponds to real-time estimation of the TR as in Orphanides (2001), who refers to this type of real-time data as "within-quarter estimates." Formally, we estimate the backward-looking TR (1) and forward-looking TR (2) as:

$$
\begin{gathered}
i_{t}=c+\theta_{i} i_{t-1}+\theta_{\pi}\left(\pi_{t-1}-\pi^{*}\right)+\theta_{y} \hat{y}_{t, t}, t=2001 Q 2-2016 Q 1 \\
i_{t}=c+\theta_{i} i_{t-1}+\theta_{\pi}\left(\hat{\pi}_{t+2, t}-\pi^{*}\right)+\theta_{y} \hat{y}_{t, t}, t=2001 Q 2-2016 Q 1,
\end{gathered}
$$

where $\hat{y}_{t, t}$ denotes the nowcast of the output gap in $t$ as estimated in each quarter $t$ (i.e. the main diagonal of Table 1). Note that the coefficient $\theta_{y}$ no longer carries a vintage subscript; it is a constant. Equivalently, in the forward-looking Taylor rule (equation 2.2), $\hat{\pi}_{t+2, t}$ denotes the two-quarters-ahead core inflation as forecast in $t$. As we will show, both methodologies produce very similar coefficients for the TR variables.

\footnotetext{
${ }^{17}$ The first estimation (i.e., for $v=2007 Q 2$ ) is done on quarterly data spanning 2001Q2 to 2007Q2. This amounts to only 25 observations. Moreover, vintages of the output gap range from extensively revised (early in the sample) to nearly unrevised (at the end of the sample) (Koenig et al. 2003).

${ }^{18}$ Using this methodology, we can only start the analysis of the effects of monetary policy shocks at the firm-level in 2007Q2, instead of 2001Q2. Thus, potentially 2,500 firm-level observations are lost ( $25 \times 100$, i.e., number of survey waves times the average number of firms per survey wave).

${ }^{19}$ The authors moreover argue that first-release left-side data should be used, based on the assumption that revisions to the dependent variable are unpredictable using data available at the time it is issued. Obviously, that is the case in the context of our research because the overnight rate, by definition, is never revised.
} 
Charts 3 to 5 illustrate the estimated parameters of a standard backward-looking TR (equation 1) using both real-time regression methods discussed above, i.e., à la SC (equation 1.1) and à la KDP (equation 1.2). As noted above, the value of each coefficient of the TR variables changes with each vintage of data in estimations à la SC. On the contrary, real-time regressions à la KDP produce timeinvariant coefficients (horizontal thick lines in Charts 3 to 5 ) because only one sample (of up-to-date estimates at each point in time) is used for the estimation.

The estimated coefficients shown in Charts 3 to 5 (thick lines) are broadly in line with their expected signs. ${ }^{20}$ Monetary policy tends to contract in response to positive output and inflation gaps, as illustrated by the positive coefficients throughout all estimation periods in Charts 4 and 5 , respectively. The 95 per cent confidence intervals (dashed lines) derived from SC and KDP estimations overlap significantly in each of the charts, suggesting that the coefficients estimated under the two different methodologies are not significantly different from each other. ${ }^{21}$ This result lends credibility to the argument that one may use real-time regression à la KDP (our "preferred" real-time method of estimation) to produce consistent estimates of TR parameters. Hence, in the remainder of the paper, we focus on TRs estimated à la KDP and on their corresponding monetary policy shocks (i.e., residuals).

Table 4a shows regression results for variations of the TR estimated à la KDP. Column 1 shows the estimated coefficients in a standard backward-looking TR (equation 1.2). The coefficients on both inflation and output gaps are positive, as expected, and are significant at conventional levels (5 and 1 per cent respectively). The output gap appears to carry more weight in the standard TR. ${ }^{22}$ The estimated coefficient of the lagged overnight rate is highly significant ( 1 per cent), and underscores the importance of interest rate smoothing in the Canadian monetary policy rule. ${ }^{23}$ Column 2 shows a forward-looking TR where lagged total inflation is replaced with the Bank's real-time two-quarters-ahead forecast of core inflation (equation 2.2). The results are qualitatively similar to those of column 1, although the inflation gap now appears to carry more weight than the output gap.

\footnotetext{
${ }^{20}$ This observation also holds when TRs augmented with measures of business sentiment are estimated à la SC and KDP (not shown but available upon request).

${ }^{21}$ This is also the case for the different versions of the TR (results not shown but available upon request).

${ }^{22}$ Both variables are measured as differences in per cent, so their coefficient estimates are comparable.

${ }^{23}$ It is important to note though that, over the period of estimation, the overnight rate remained equal to 1 per cent for 17 quarters (i.e., from 2010Q4 to 2014Q4) in the aftermath of the Great Recession. Hence, an alternative interpretation of the high coefficient is interest rate persistence (rather than smoothing).
} 
This suggests that the Bank responds more strongly to anticipated core inflation than to past total inflation, which is in line with the literature (e.g., Markov and Nitschka 2013).

The rest of Table 4a shows how the previous estimation results are affected when a measure of business sentiment, here the BOS indicator, is included in the TR. The main takeaway message here is that measures of business sentiment appear to positively influence interest rate decisions: a onestandard-deviation drop of the indicator would call for a rate cut of roughly 23 basis points. ${ }^{24}$ Columns 3 and 4 show that the output gap loses its explanatory power (at conventional levels) when a measure of business sentiment is included in the TR. The next two columns, i.e., columns 5 and 6 , replace the output gap with a measure of business sentiment, with similar results. ${ }^{25}$ In other words, monetary policy tends to tighten (ease) in response to an improvement (a deterioration) in business sentiment.

Table 4a provides empirical support to Murray's (2013) description that the Bank's Governing Council has a holistic approach when deciding on the appropriate monetary stance in Canada. Not only does the Bank's Governing Council rely on official hard data, and on the Bank's own complex economic models, when taking monetary policy decisions, but it also takes into account business sentiment, or soft data derived from business surveys. An alternative interpretation is that business sentiment is not an additional data source in the TR, but rather an alternative to the output gap. Indeed, measures of business sentiment are reliable and timely measures of economic conditions (compared to the output gap, which is imperfectly estimated at the time of the interest rate decision since GDP is published with lags and often subject to large revisions). Business sentiment may thus potentially be more pertinent than estimates of the output gap for monetary policy decisions in real time. ${ }^{26}$ Whether business sentiment is an additional variable or simply a potentially better way of measuring the output gap, the results suggest that it appears to play a significant role in determining monetary policy rates, at least in Canada.

\footnotetext{
${ }^{24}$ As there is no natural unit of measurement for the BOS indicator, its values have been standardized (centred on its mean and divided by its standard deviation). Hence, the coefficients of the BOS indicator are interpretable in terms of units of standard deviations.

${ }^{25}$ Note that excluding the output gap from the model tends to result in lower standard errors of the estimates (i.e., columns 5 and 6 vs. columns 3 and 4), potentially suggesting that the output gap added noise in the previous specification, while the adjusted R-squared are unchanged.

${ }^{26}$ The correlation of the BOS indicator with the (end-of-sample revised) output gap is about 0.56 at $t+1$.
} 
The results are robust to a number of variations of the specification. First, using the IBC instead of the BOS indicator over the same sample period yields similar results. ${ }^{27}$ Indeed, the two indicators are highly correlated (72 per cent). As in Table 4a, the inflation gap is only statistically significant in the forward-looking specification (column 4) when the measure of business sentiment is added to the TR, while the output gap loses its explanatory power. The IBC carries a coefficient of around 0.2-0.24 in the augmented and alternative specification of the TR, suggesting that an improvement in business sentiment of one standard deviation is associated with a policy rate hike of 0.22 basis points. This suggests that it is not the survey conducted by the Bank itself that matters for monetary policy; rather, it is business sentiment more generally that appears to have explanatory power in a TR, whether measured by the BOS or measured by surveys from other institutions.

Second, one might believe that the results are mainly driven by the recession, which witnessed a dramatic drop in both business sentiment and policy rates. Luckily, the IBC sample allows us to crosscheck our results with a longer sample starting in 199304. Results are qualitatively very similar (Table 4b). The inflation gap now carries more weight, a result that is likely driven by the fact that the Bank focused mainly on controlling inflation in the earlier part of the sample, following the official adoption of the inflation target in $1991 .^{28}$ The output gap is not statistically significant in any specification. Most importantly, the measure of business sentiment, the IBC in this case, carries a highly statistically significant coefficient of around 0.29, i.e., even larger, at the margin, than in the original specification with the shorter sample.

\section{Forecasting performance}

Chart 6 compares the actual policy rate (in blue) to policy rates predicted by variants of the TR (in red, green and purple; see also Table 4a). Interestingly, while interest rate forecasts given by all TRs broadly track the actual rate, they deviate visibly in some quarters, suggesting that monetary policy was either too loose or too tight, judging from the TR. For instance, predicted overnight rates from all TR versions called for more monetary policy easing as they crossed the zero lower bound at the peak of the recession (in 2009Q3), while the actual policy rate remained at 0.5 per cent, the level the Bank judged to

\footnotetext{
${ }^{27}$ Results not shown but available upon request.

${ }^{28}$ Indeed, the monetary policy reaction function at the time was described as being a function of the inflation gap only (Coletti et al. 1996).
} 
be the effective lower bound at that time. ${ }^{29}$ In 2015Q4, actual policy rates were in line with the standard TR (last data point) when the oil price shock took its toll on the economy more broadly. But augmented TRs called for an additional rate cut, which reflects the fact that measures of business sentiment plummeted that quarter (in contrast to the nowcast of the output gap, which was revised down only in subsequent quarters).

To formally evaluate the current quarter forecast accuracy of the different TRs presented in Table 4a, we calculate their root-mean-squared error (RMSE) and their mean absolute error (MAE). We also present results where the BOS indicator is replaced with the IBC. Table 5 indicates that the augmented TRs (i.e., column 2) have better prediction accuracy both in the standard and in the forward-looking TRs (i.e., column 1): the RMSE and the MAE are roughly 17 per cent lower when using the BOS, and 9 to 13 per cent lower when using the IBC. The results again suggest that monetary policy is better described by a TR augmented with measures of business sentiment. The alternative TRs (i.e., column 3), where the output gap is replaced by a measure of business sentiment, appear to be as accurate in terms of prediction as the augmented TRs.

In the following, we will use the fitted residuals derived from the estimated TRs as measures of the stance of monetary policy and study their effects on firms. TR residuals are a good approximation of monetary policy shocks because residuals capture the portion of interest rate movements not explained by the central bank's responses to deviations of inflation from target, and output from potential output (Orphanides 2001). Residuals obtained from the standard TR will serve as a benchmark. We will also use residuals from TRs including measures of business sentiment, in particular, those of alternative TRs (which replace the output gap with business sentiment), since they are as accurate in terms of forecasting as augmented TRs, as shown in Table 5.

\section{The Impact of a Monetary Policy Shock on Firms}

In this section, we study the effects of monetary shocks at the firm level, i.e., on firms' business perspectives, or outcomes, as they are measured in the BOS.

\footnotetext{
${ }^{29}$ Note that the Bank provided additional monetary easing through unconventional tools during the crisis using forward guidance about the future path of policy rates; i.e., it committed to keeping policy rates at 0.5 per cent over the April 2009-June 2010 period, conditional on the path of inflation.
} 


\subsection{Econometric modelling and conceptual issues}

Given the ordinal nature of the dependent variables at the firm level, with response ordering typically going from "lesser" to "greater" (see Appendix A), such that larger values are assumed to correspond to "higher" outcomes, we model firm outcomes by estimating ordinal logistic regressions.

We use firm-level responses regarding the expected dynamics of their sales growth as an example of a firm outcome:

$$
\text { FutureSales }_{i t}=\gamma^{\prime} * X_{i t}+\varphi^{\prime} * \text { macro }_{t-1}+\emptyset_{s} * \sum_{i=0}^{i=s} \text { Monetary_Policy_shock }_{t-i},
$$

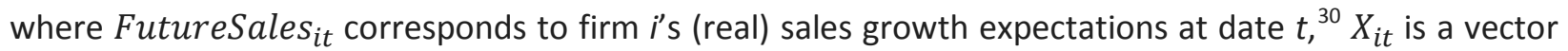
containing dummy variables that capture BOS firm-level characteristics (including size, sector and province) at date $t$, and $\gamma$ is a vector of parameters. macro $_{t-1}$ is a vector of macroeconomic variables, and $\varphi$ is a vector of parameters. ${ }^{31,32}$

The identification strategy for the firm-level estimations rests on the assumption that monetary policy affects economic activity, and hence firms' business perspectives, with a lag (Stock and Watson 2001; Christiano et al. 1999; Romer and Romer 2004). We provide some support for that identifying assumption by estimating a simple bivariate SVAR, ordered as (i) a BOS variable expressed as a balance of opinion (e.g., of future sales), ${ }^{33}$ and (ii) the overnight rate targeted by the Bank. Equation (ii) is essentially a version of the TR in which the Bank is modelled as setting the overnight rate based on past

\footnotetext{
${ }^{30}$ The variable takes the value 1 if the firm responds "growing at a greater rate," 0 if the firm responds "same rate" and -1 if the firm responds "lesser rate."

${ }^{31}$ The specifications also include quarter dummies to capture any potential seasonal effects.

32 Since this equation uses generated regressors (i.e., the TR residuals), one would ideally want to adjust the variance-covariance matrix to account for the fact that regressors are measured with sampling error (Newey 1984; Pagan 1984). While the literature has come forth with corrected standard errors for linear estimation cases (Murphy and Topel 1985; Pichette 1998), to our knowledge, the literature has not addressed a two-step estimation case where the second step is a complex non-linear model such as an ordered logit regression. A recommended simpler or alternative approach (Cameron and Trivedi 2005; Wooldridge 2002) is to obtain bootstrap standard errors. As examples (not shown but available upon request), we recomputed bootstrap standard errors $(1,000$ replications) for future sales and future sales indicators, and this did not change the significance of the results. Finally, estimating the effects of monetary shocks on BOS variables in a bivariate structural VAR setting (see discussion below), which circumvents the aforementioned problem altogether, did not alter the significance of the results in most cases (see next section).

${ }^{33}$ The first equation (i.e., (i)) estimated in the SVAR (not shown for the sake of brevity) has exactly the same structure as the interest rate equation (ii).
} 
rates of inflation and the IBC (instead of the output gap based on the results of section 3.2 ). ${ }^{34}$ In this system, the Bank sets the overnight rate $i_{t}$ according to the rule (using future sales as an example):

$$
i_{t}=c+\Theta_{\pi}\left(\pi_{t-1}-\pi^{*}\right)+\Theta_{I B C} I B C_{t-1}+\text { lagged value of } i \text {, future sales }+\varepsilon_{t} \text {, }
$$

where the terms $\left(\pi_{t-1}-\pi^{*}\right)$ and $I B C_{t-1}$ (lagged Index of Business Confidence) are treated as exogenous variables. ${ }^{35}$ The parameter $\Theta_{I B C}$ is the sensitivity of the overnight rate to the IBC, and $\varepsilon_{t}$ is the error in the equation. This relationship becomes the interest rate equation in the SVAR.

Returning to the analysis at the firm level, the identification strategy employed is in reference to the above SVAR and is based on the recursiveness assumption. As stated by Christiano et al. $(1999,68)$ : "The economic content of the recursiveness assumption is that the time $t$ variables in the Fed's information set do not respond to time $t$ realizations of the monetary policy shock [defined as the fitted residuals of the Fed's feedback rule]."

Moreover, it is important to understand that a firm outcome, as measured in the BOS, is a relative outcome spanning two time periods. Conceptually, to answer a BOS question, a firm is asked to compare a given measure of business activity for a forward-looking period (year ahead) to a baseline period (past year). For example, at the time a firm is surveyed (quarter $t$ in Chart 7), the firm is asked to compare its expected sales growth over the next four quarters ( $t$ to $t+4)$ to growth over the past four quarters ( $t$-4 to $t$ ). The firm then provides a qualitative answer (e.g., same rate) summarizing this comparison.

Putting the aforementioned pieces together, we define a contemporaneous shock (i.e., the fitted residual of a TR) as a shock happening during the measurement period of a firm outcome, generally the baseline period (i.e., $t-4$ to $t$ in Chart 7). ${ }^{36}$ In the SVAR setting, a contemporaneous monetary shock does not, by definition, have a contemporaneous effect on a given firm outcome (e.g., future sales). However, given that we operate in a single-equation framework at the firm level, we cannot impose such an identification restriction. Nevertheless, if we believe monetary policy operates with a lag, then we can

${ }^{34}$ Using the IBC instead of the BOS indicator circumvents any endogeneity problems that might arise when estimating equation (i), i.e., the first equation in the VAR, because some information contained in the dependent variable, i.e., the BOS variable, is included the BOS indicator (see Table A2).

${ }^{35}$ The relatively short history of the survey ( 15 years multiplied by 4 quarters equals 60 data points) allows for limited degrees of freedom in the SVAR framework.

${ }^{36}$ Using the BOS indicator in the TR and the fitted residuals as monetary policy shocks lessens potential endogeneity problems that might arise when analyzing the effects of monetary policy shocks at the firm level. 
assume that any effect detected using contemporaneous shocks should reveal the response of monetary policy to current and expected economic conditions, and not vice versa. In short, contemporaneous shocks should reveal reverse causality.

In the spirit of the SVAR's identification restrictions, we define an exogenous shock as a shock that happened before the measurement period of a firm outcome, i.e., before the baseline period ( $t-4$ to $t$ in Chart 7). Again, if we believe monetary policy affects economic activity with a lag, any effect being detected using exogenous shocks should show the actual response of the economy, here from a firm perspective, to unexpected changes in the monetary stance. In short, exogenous shocks should reveal the causal effects of monetary policy.

Two more comments on the identification strategy are worth mentioning. First, we do not claim, in general, to identify the effects pertaining to a specific transmission channel (e.g., the interest rate channel) of monetary shocks. Rather, we assume that effects detected at the micro level encompass the overall effects of unexpected changes in the target rate. Second, as in Friedman's (1953) analogy with billiard players, the results are not based on firms being attentive to unexpected changes in the monetary stance. ${ }^{37}$ Firms are assumed to adapt their business perspectives as the effects of monetary shocks are being felt across the economy.

\subsection{Econometric results and robustness checks}

\section{Future sales}

Table 6 shows the estimated coefficient of contemporaneous and exogenous monetary shocks on firms' expected (real) sales growth. Results in each cell refer to a different specification; the three lines refer to three different measures of monetary policy shocks, and columns refer to different time horizons of the shock. For instance, results in the first line denote results using shocks derived from the standard TR, which will serve as a benchmark. The second and third rows show the estimated effects using shocks obtained from alternative TRs (i.e., using the BOS indicator instead of the output gap in the second line and the IBC in the third line).

\footnotetext{
${ }^{37}$ This does not mean that we assume that all firms in our sample are inattentive to monetary policy decisions. However, the BOS data do not allow us to differentiate the effects of monetary shocks between firms that are attentive to monetary policy announcements (anticipation effects) and those that are not.
} 
Results moving across columns denote the estimated coefficients using different time lags of the monetary policy shock variable. Because monetary policy decisions, and to a certain extent monetary shocks, tend to be correlated over time (see Table 4a), we bypass collinearity problems by using sums of TR residuals. ${ }^{38}$ Another advantage of using shocks defined as sums of TR residuals is that we directly obtain the cumulative effect of monetary shocks over a given time horizon. This is especially relevant for an intuitive interpretation of the results, given that we are studying the effects of monetary shocks in a non-linear setting (i.e., ordinal logistic regression). For instance, the results using contemporaneous shocks (as defined above) illustrate how the effects of recent monetary surprises vary over time as we gradually "go back in time." 39,40

As hypothesized in the previous section, a purely contemporaneous shock (i.e., one that happens in the current quarter-Lag 0) reveals reverse causality, at least in the cases of a standard TR shock (Table 6, column 1, row 1 ) and of a shock derived from an alternative TR including the BOS (row 2). In other words, stronger expected sales dynamics are associated with a contraction of the monetary stance in the current quarter (i.e., odds ratios significantly larger than one). ${ }^{41}$

On the contrary, when exogenous (or lagged) shocks are considered, monetary policy consistently has the effects one would expect. In the current context, an exogenous monetary shock is a shock that occurred a little over a year ago (Table 6, column 6-Lag 5-to column 10-Lag 5 to Lag 9). An unexpected tightening in the monetary stance leads to slower expected sales dynamics (i.e., odds ratios significantly smaller than one) over the coming year. These results are consistent with economic intuition regarding, first, the causal effect of monetary policy and, second, the fact that monetary policy affects (real) economic activity with a lag. Moreover, the effects of exogenous shocks derived from the standard TR or from alternative TRs are now qualitatively similar. ${ }^{42}$

\footnotetext{
${ }^{38}$ These shocks (i.e., residuals) are derived from real-time regressions à la KDP (see section 3.2).

${ }^{39}$ As a robustness check, we also did the analyses with separate TR residuals (i.e., one for each quarter over the past two years; results are not shown but are available upon request). Results are qualitatively similar, although the standard errors of shocks are much larger because of collinearity problems.

${ }^{40}$ Note that as we include a new quarter of data within a cumulative shock (e.g., Table 6, moving from column 2Lag 0 to Lag 1 -to column 3-Lag 0 to Lag 2), we lose roughly 100 observations (i.e., the number of BOS firms visited each quarter).

${ }^{41}$ A more accurate statement is that a contemporaneous monetary shock increases the likelihood that a firm reports a greater rate of expected sales growth relative to an unchanged or a lesser rate of growth of future sales. For the sake of brevity, we prefer to use the shorthand form used here throughout the text.

${ }^{42}$ Control variables are statistically significant in most specifications and have the expected sign. In particular, stronger lagged US or Canadian growth increases the odds of the firm reporting stronger past sales growth. Several
} 
The impulse-response analysis of future sales (balance of opinion) based on the SVAR framework discussed in the previous section supports these conclusions. Chart 8 plots the impulse-response function of future sales to a monetary shock. Expectations of business activity are significantly and persistently dampened following an unexpected tightening in the monetary stance. ${ }^{43}$

We verify the robustness of the firm-level regression results with two robustness checks. First, we use shocks derived from forward-looking TRs (i.e., see equation 2 in section 3.1). Overall, the results still hold (Appendix B, Table B1). A contemporaneous monetary policy shock (first column) carries a coefficient above one, indicative of reverse causality (i.e., a monetary policy contraction is associated with faster expected sales growth). Exogenous shocks, as before, carry coefficients below one, suggesting that tighter monetary policy tends to lead to slower expected sales growth.

Second, we restrict the BOS sample to include only firms that rely on external financing and are thus potentially affected by the interest rate channel of monetary policy (Appendix C, Table C1). In other words, only firms that answer the question regarding their credit conditions over the past three months are included in the BOS sample (henceforth the credit condition sample). ${ }^{44}$ Using contemporaneous shocks, results again point to reverse causality. Exogenous shocks, to the contrary, suggest that monetary policy tightening tends to lead to slower expected sales growth. The results based on the credit condition sample also suggest that the causal effects are even stronger than those for the whole sample: the odds ratios associated with exogenous shocks, derived from the credit conditions sample (Table C1, columns 6 to 10), are systematically smaller than those for the whole sample (Table 6, columns 6 to 10$)$, although sometimes not by much. ${ }^{45}$

firm size, sector and region dummies are also statistically significant, which are overall consistent with economic intuition. For instance, firms in British Columbia are more likely to report stronger past sales growth compared with other regions, which is consistent with average survey data as well as actual GDP growth data.

${ }^{43}$ This finding is robust to the inclusion of lagged real US GDP growth (Q/Q, SAAR) and WTI oil price (USD) growth $(\mathrm{Q} / \mathrm{Q})$ as exogenous variables in the SVAR (Chart E1). Keep in mind that the relatively short history of the survey (15 years multiplied by 4 quarters equals 60 data points) allows for limited degrees of freedom in the SVAR framework. Standard errors of the estimates tend to increase with the inclusion of the aforementioned exogenous variables.

${ }^{44}$ For this survey question, roughly 20 per cent of responses are missing; i.e., firms respond "not applicable." Almost all of these pertain to firms that are fully self-financed; a question on whether credit conditions tightened or eased has little relevance for these firms since they do not rely on external financing. We can reasonably assume that the interest rate channel of monetary policy is different or less pronounced for these firms.

${ }^{45}$ For the sake of transparency, we also include results based on the "continuous" sum of monetary shocks (i.e., the residuals are continuously summed over time-contemporaneous and exogenous shocks are "lumped" 


\section{Indicators of future sales}

To a certain extent, the preceding pattern of results holds for almost all of the other BOS firmlevel responses examined. For instance, similar conclusions hold when we estimate the impact of a monetary policy shock on firms' indicators of future sales, such as new orders and advanced bookings (Table 7). This variable has proven to be one of the most informative variables in the BOS, with a peak correlation with year-on-year business GDP growth at one quarter ahead (Table 1). While a contemporaneous monetary policy contraction is associated with an improvement in indicators of future sales-i.e., monetary policy would tend to tighten when firms' sales indicators improve, as indicated by odds ratios larger than one (Table 7, columns 1 to 5 )-an exogenous tightening in monetary policy appears to lead to a deterioration in firms' future sales indicators (Table 7, columns 6 to 10), consistent with the expected lagged effect of monetary policy. ${ }^{46,47}$

Chart 9 plots the impulse-response function of indicators of future sales (balance of opinion) to a monetary shock derived from the same SVAR framework as before. Although the effect of the shock takes some time to build up, expectations of business activity are eventually significantly dampened. Interestingly, the effect of the shock becomes significant at roughly the same time horizon (around Lags 7 and 8) as in the firm-level estimations based on the IBC shocks (Table 7, third row). ${ }^{48}$

\section{Credit conditions}

We next examine the effects of monetary policy shocks on firms' assessment of their credit conditions (Table 8). An estimated coefficient, expressed in terms of odds ratios, significantly larger than one means that a firm is more likely to report a tightening in its credit conditions. One might argue that the current monetary policy shock (i.e., in Lag 0 ) should not be expected to affect credit conditions since

together). For future sales (Appendix D, Table D1), the pattern of results is essentially unchanged but the causal effects (columns 6 to 9) are somewhat less pronounced (i.e., odds ratios closer to but still smaller than one).

${ }^{46}$ Results are again robust to using shocks obtained from a forward-looking TR (Appendix B, Table B2), as well as using the smaller sample of firms relying on external financing (Appendix C, Table C2).

${ }^{47}$ Of note, whereas the number of observations diminishes for all other variables discussed as we consider monetary policy shocks extending over longer time horizons (i.e., moving to the right in the estimation tables), the number of observations is constant in the case of future sales indicators (because the series starts in 2003 only and we thus do not lose any observations when using longer lags of monetary policy shock estimates, available from 2001 onwards). The fact that the results are qualitatively similar to the ones obtained for the future sales variable is reassuring because it indicates that it is not changes in sample (size) that are driving the results.

${ }^{48}$ This finding is broadly robust to the inclusion of lagged real US GDP growth $(\mathrm{Q} / \mathrm{Q}, \mathrm{SAAR})$ and WTI oil price (USD) growth $(\mathrm{Q} / \mathrm{Q}$ ) as exogenous variables in the SVAR (Chart E2). 
the survey question refers to the past three months (Appendix A). Yet, in practice, interviews take place around the middle of the quarter (e.g., in February for the Q1 survey), when one of the two interest rate decisions during that quarter has already been announced. Thus it is not unreasonable to assume that the contemporaneous monetary policy shock may affect credit conditions as reported by firms. Yet, we also estimate the impact excluding the contemporaneous shock, with similar results.

Results for credit conditions follow the intuitions discussed for the dynamics of future sales. Contemporaneous shocks (Table 8, columns 1 to 5 , rows 1 to 3 ) are indicative of reverse causality (i.e., a current contraction in the monetary stance is generally associated with looser credit conditions-odds ratios significantly smaller than one). We interpret this result as evidence that (too) loose credit conditions may be associated with expected growth above potential, as credit is more easily available during periods of economic expansion. In turn, this leads the monetary authority to decide to raise interest rates to avoid a buildup of inflationary pressures. On the contrary, results for exogenous shocks are in line with economic intuition; i.e., past contraction in the monetary stance leads to tighter credit conditions being reported today (odds ratios significantly larger than one; Table 8, columns 6 to 10, rows 1 to 3 ). These results provide clear evidence for the interest rate channel of monetary policy. ${ }^{49}$

As before, the preceding pattern of results is supported by the impulse-response function of credit conditions (balance of opinion) (Chart 10) to a monetary shock derived from the SVAR. ${ }^{50}$

\section{Output prices}

We briefly discuss results for three other variables of interest. Firms tend to expect slower output price growth in response to exogenous monetary policy shocks (Table 9, columns 5 to 9), regardless of whether the standard or the alternative measure of monetary policy shock is used. This is consistent with our priors that monetary policy negatively affects output price growth with an important lag. ${ }^{51}$

\footnotetext{
${ }^{49}$ As before, results are essentially unchanged when using shocks derived from forward-looking TRs (Appendix B, Table B3).

${ }^{50}$ This finding is broadly robust to the inclusion of lagged real US GDP growth $(\mathrm{Q} / \mathrm{Q}, \mathrm{SAAR})$ and WTI oil price (USD) growth $(\mathrm{Q} / \mathrm{Q}$ ) as exogenous variables in the SVAR (Chart E3).

${ }^{51}$ The estimated coefficients above 1 at the 0 to 2 and 0 to 3 quarter lag suggest we estimate reverse causality effects (i.e., if firms report acceleration in their prices, the monetary policy authority would be more likely to tighten the stance).
} 
Chart 10 plots the impulse-response function of expected output price growth (balance of opinion) to a monetary shock (SVAR) and suggests the same dynamics are at play. ${ }^{52}$

\section{Wages}

The same logic applies to results for wage dynamics (Table 10) at the firm level, which also exhibits evidence of reverse causality at shorter horizons of monetary policy shocks. However, exogenous shocks results are statistically significant only when using residuals obtained from alternative TRs (columns 6 to 10, rows 2 and 3). Moreover, even though Chart 12 shows that expected wage growth (balance of opinion) tends to decline following a monetary shock (SVAR), the confidence bands are wide, and thus the results are not significant at the 5 per cent level.

\section{Investment intentions}

For firms' investment plans (Table 11), results are intuitive, but only at long horizons: firms tend to report weaker investment intentions in the two to three years following a monetary policy shock. The lack of evidence of the monetary policy transmission channel to investment decisions at shorter horizons might be surprising as theory would generally predict a rather fast response of investment to changes in interest rates. Yet, analysis of firm surveys has documented that firms' investment intentions are often insensitive to interest rates, and thus in line with our results. ${ }^{53}$ Chart 13 shows that investment intentions (balance of opinion) tend to decline following an unexpected tightening of the monetary stance (SVAR). But, as in the case of expected wage growth, the results are not significant at the 5 per cent level.

\section{Conclusion}

What information does the Governing Council of the Bank of Canada take into account when deciding on the level of the policy rate? The Taylor rule would suggest that monetary policy is well described as a function of the output gap and the deviation of inflation from the target rate. We modify the Taylor rule to show that policy-makers take into account additional sources of information, including

\footnotetext{
${ }^{52}$ This finding is broadly robust to the inclusion of lagged real US GDP growth ( $\left.Q / Q, S A A R\right)$ and WTI oil price (USD) growth $(\mathrm{Q} / \mathrm{Q}$ ) as exogenous variables in the SVAR (Chart E2).

${ }^{53}$ The Reserve Bank of Australia, for instance, documents that firms tend to require expected returns on capital expenditure to exceed high "hurdle rates" of return that are often well above the cost of capital and do not change very often. As a consequence, the capital expenditure decisions are not that sensitive to changes in interest rates (Lane and Rosewall 2015).
} 
soft data from business surveys. Specifically, we use measures of business sentiment derived from the Bank of Canada's quarterly Business Outlook Survey (BOS) and from the Conference Board of Canada's business confidence survey (BCS). These surveys provide a timely assessment of business conditions and, thus, of the state of the economy, and they have the advantage (over other data sources) that they are not revised. We show, using the Taylor rule in real time, that there is a positive, significant and systematic relationship between the Canadian overnight rate and these measures of business sentiment. We also find that these business sentiment measures eclipse the output gap's explanatory power in the Taylor rule.

This paper also provides new insights into the effects of monetary policy at the firm level. We define monetary policy shocks as the fitted residuals of the Taylor rule and study their effects on firms' business perspectives as they are measured in the BOS. Unexpected changes in the target rate that happen during the measurement period of a firm's response are defined as contemporaneous shocks, whereas those that happen before are defined as exogenous. We find that contemporaneous shocks almost systematically capture reverse causality; i.e., we appear to measure the response of monetary policy to business activity, rather than vice versa. On the contrary, exogenous shocks provide systematic, clear and intuitive support to the lagged and causal effect of monetary policy. For instance, an unanticipated tightening in monetary policy a year ago (or more) significantly increases the likelihood that a firm will report tighter lending conditions today, or will expect slower dynamics of future sales and output prices. Overall, the results at the firm level are qualitatively similar whether shocks are derived from a standard Taylor rule (including only hard data) or from an alternative Taylor rule (also including soft data). They are also robust to using shocks derived from forward-looking TRs, and to using a restricted sample of BOS firms that are potentially affected by the interest rate channel. Finally, the results are generally in agreement with the qualitative effects of monetary policy shocks described in the literature, and with those of the simple bivariate SVAR that we estimate.

Several extensions would be worthwhile to pursue in future research. First, with several more years of data available, a panel setting using BOS balances of opinion by sector, size or region could yield additional insights into the effects of monetary policy on firm perspectives. Second, as Romer and Romer's (2004) narrative approach has come to be seen as the "golden standard" for the definition of exogenous monetary policy shocks in the literature, we aim to use this alternative series of shocks in the 
context of the BOS data in future versions of the paper. ${ }^{54}$ And finally, it would be insightful to further exploit the data to investigate whether small firms respond differently compared with large firms to monetary policy shocks, as suggested by Ehrmann (2004).

\footnotetext{
${ }^{54}$ While the Romer and Romer (2004) estimate of the monetary policy stance has been used extensively in research on US monetary policy, such a measure does not yet exist for Canada. Yet, researchers at the Bank of Canada are currently working on such a measure for Canada.
} 


\section{References}

Amirault, D., L. Martin, S. Miller and J. Pinto. 2017. "The Business Outlook Survey After 20 Years: Taking Stock." Mimeo.

Ball, L. 1999. "Policy Rules for Open Economies." In Monetary Policy Rules, edited by J. B. Taylor, 127156. Chicago: University of Chicago Press.

Batini, N. and A. Haldane. 1999. "Forward-Looking Rules for Monetary Policy." In Monetary Policy Rules, edited by J. B. Taylor, 157-192. Chicago: University of Chicago Press.

Cameron, A. C. and P. K. Trivedi. 2005. Microeconometrics: Methods and Applications. Cambridge: Cambridge University Press.

Cayen, J.-P. and S. van Norden, S. 2005. "The Reliability of Canadian Output-Gap Estimates." North American Journal of Economics and Finance 16: 373-393.

Champagne, J., G. Poulin-Bellisle and R. Sekkel. 2016. "The Real-Time Properties of the Bank of Canada's Staff Output Gap Estimates." Bank of Canada Staff Working Paper No. 2016-28.

Christiano, L. J., M. Eichenbaum and C. L. Evans. 1999. "Monetary Policy Shocks: What Have We Learned and to What End?" Handbook of Macroeconomics 1(A): 65-148.

Clarida, R., J. Galí and M. Gertler. 1998. "Monetary Policy Rules in Practice: Some International Evidence." European Economic Review 42 (6): 1033-1067.

- - . 1999. "The Science of Monetary Policy: A New Keynesian Perspective." Journal of Economic Literature 37 (4): 1661-1707.

- - . 2000. "Monetary Policy Rules and Macroeconomic Stability: Evidence and Some Theory." Quarterly Journal of Economics 115 (1): 147-180.

Coibion, O. and Y. Gorodnichenko. 2012. "Why Are Target Interest Rate Changes so Persistent?" American Economic Journal: Macroeconomics 4 (4): 126-162.

Conference Board of Canada. 2017. "Business Confidence Canada." Available at www.conferenceboard.ca/e-data/data/business-confidence.aspx.

Coletti, D., B. Hunt, D. Rose and R. Tetlow. 1996. "The Bank of Canada's New Quarterly Projection Model: Part 3, The Dynamic Model: QPM." Bank of Canada Technical Report No. 75.

Croushore, D. 2011. "Frontiers of Real-Time Data Analysis." Journal of Economic Literature 49 (1): $72-$ 100.

de Munnik, D., M. Illing and D. Dupuis. 2013. "Assessing the Accuracy of Non-random Business Conditions Surveys: A Novel Approach." Journal of the Royal Statistical Society 176 (2): 371-388. 
Dorich, J., M. Johnston, R. Mendes, S. Murchison and Y. Zhang. 2013. "ToTEM II: An Updated Version of the Bank of Canada's Quarterly Projection Model." Bank of Canada Technical Report No. 100.

Ehrmann, M. 2004. "Firm Size and Monetary Policy Transmission-Evidence from German Business Survey Data." CESifo Working Paper Series, Working Paper No. 1201, CESifo Group Munich.

Friedman, M. 1953. Essays in Positive Economics. Chicago: University of Chicago Press.

Galí, J., 2015. "Monetary Policy, Inflation, and the Business Cycle: An Introduction to the New Keynesian Framework and Its Applications." Princeton: Princeton University Press.

Gervais, O. and M.-A. Gosselin. 2014. "Analyzing and Forecasting the Canadian Economy Through the LENS Model." Bank of Canada Technical Report No. 102.

Käfer, B. 2014. "The Taylor Rule and Financial Stability-A Literature Review with Application for the Eurozone." Review of Economics 65 (2): 159-192.

Kashyap, A. K. and J. C. Stein. 2000. "What Do a Million Observations on Banks Say About the Transmission of Monetary Policy?" American Economic Review 90 (3): 407-428.

Koenig, E., F. S. Dolmas and J. Piger. 2003. "The Use and Abuse of Real-Time Data in Economic Forecasting." Review of Economics and Statistics 85 (3): 618-628.

Kozicki, S. 2004. "How Do Data Revisions Affect the Evaluation and Conduct of Monetary Policy?" Federal Reserve Bank of Kansas City Economic Review Q1 89 (1): 5-38.

Lane, K. and T. Rosewall. 2015. "Firms' Investment Decisions and Interest Rates." Reserve Bank of Australia Bulletin June Quarter: 1-7.

Maddaloni, A. and J.-L. Peydró. 2011. "Bank Risk-Taking, Securitization, Supervision, and Low Interest Rates: Evidence from the Euro-Area and the U.S. Lending Standards." The Review of Financial Studies 24 (6): 2121-2165.

Markov, N. and T. Nitschka. 2013. "Estimating Taylor Rules for Switzerland: Evidence from 2000 to 2012." Swiss National Bank Working Paper No. 2013-08.

Martin, M. and C. Papile. 2004. "The Bank of Canada's Business Outlook Survey: An Assessment." Bank of Canada Working Paper No. 2004-15.

Murphy, K. M. and R. H. Topel. 1985. "Estimation and Inference in Two-Step Econometric Models." Journal of Business \& Economic Statistics 3 (4): 370-79.

Murray, J. 2013. "Monetary Policy Decision Making at the Bank of Canada." Bank of Canada Review (Autumn): 1-9.

Newey, W. K. 1984. "A Method of Moments Interpretation of Sequential Estimators." Economics Letters 14 (2-3): 201-206. 
Orphanides, A. 2001. "Monetary Policy Rules Based on Real-Time Data." American Economic Review 91 (4): 964-985.

Orphanides, A. and S. van Norden. 2002. "The Unreliability of Output-Gap Estimates in Real Time." Review of Economics and Statistics 84 (4): 569-583.

Pagan, A. 1984. "Econometric Issues in the Analysis of Regressions with Generated Regressors." International Economic Review 25 (1): 221-247.

Pichette, L. 1998. "La politique monétaire a-t-elle des effets asymétriques sur l'emploi?” Bank of Canada Staff Working Paper No. 1998-17.

Pichette, L. 2012. "Extracting Information from the Business Outlook Survey Using Statistical Approaches." Bank of Canada Staff Discussion Paper No. 2012-8.

Pichette, L. and L. Rennison. 2011. "Extracting Information from the Business Outlook Survey: A Principal-Component Approach." Bank of Canada Review (Autumn): 21-28.

Pichette, L., P. St-Amant, B. Tomlin and K. Anoma. 2015. "Measuring Potential Output at the Bank of Canada: The Extended Multivariate Filter and the Integrated Framework." Bank of Canada Staff Discussion Paper No. 2015-1.

Pichette, L. and M.-N. Robitaille. 2017. "Assessing the Business Outlook Survey Indicator Using Real-Time Data." Bank of Canada Staff Discussion Paper No. 2017-5.

Romer, C. D. and D. H. Romer. 2004. "A New Measure of Monetary Shocks: Derivation and Implications." American Economic Review 94 (4): 1055-1084.

Rudebusch, G. and L. Svensson. 1999. "Policy Rules for Inflation Targeting." In Monetary Policy Rules, edited by J. B. Taylor, 203-246. Chicago: University of Chicago Press.

Stark, T. and D. Croushore. 2002. "Forecasting with a Real-Time Data Set for Macroeconomists." Journal of Macroeconomics 24 (4): 507-531.

Stock, J. H. and M. W. Watson. 2001. "Vector Autoregressions." Journal of Economic Perspectives 15 (4): 101-115.

Svensson, L. E. 2000. “Open-Economy Inflation Targeting." Journal of International Economics 50 (1): 155-183.

Taylor, J. B. 1993. "Discretion versus Policy Rules in Practice." Carnegie-Rochester Conference Series on Public Policy, 195-214.

- - . 2013. "International Monetary Coordination and the Great Deviation." Journal of Policy Modeling 35 (3): 463-472. 
Tkacz, G. 2010. “An Uncertain Past: Data Revisions and Monetary Policy in Canada." Bank of Canada Review (Spring): 41-51.

Wooldridge, J. M. 2002. Econometrics Analysis of Cross Section and Panel Data. Cambridge, Massachusetts: The MIT Press. 


\section{Tables and Charts}

Table 1: Correlations of key BOS variables with economic variables (2001Q2 to 2016Q1)

\begin{tabular}{|c|c|c|c|c|c|c|c|c|c|c|}
\hline \multirow[b]{2}{*}{ Survey variable } & \multirow[b]{2}{*}{ Economic variable } & \multicolumn{9}{|c|}{ Correlation } \\
\hline & & $\mathrm{T}-4$ & $T-3$ & $T-2$ & $\mathrm{~T}-1$ & $T$ & $T+1$ & $T+2$ & $T+3$ & $T+4$ \\
\hline \multirow{2}{*}{ Future sales } & GDP momentum & -0.256 & -0.167 & -0.070 & 0.051 & 0.290 & 0.535 & 0.684 & 0.661 & 0.359 \\
\hline & GDP growth $(y / y)$ & -0.404 & -0.413 & -0.405 & -0.299 & -0.003 & 0.347 & 0.558 & 0.622 & 0.499 \\
\hline $\begin{array}{l}\text { Future sales indicator } \\
\text { (starting 2003Q3) }\end{array}$ & GDP growth $(y / y)$ & -0.050 & 0.114 & 0.336 & 0.554 & 0.760 & 0.879 & 0.797 & 0.587 & 0.344 \\
\hline Investment in M\&E & $\begin{array}{l}\text { Real business investment } \\
\text { (M\&E) growth }\end{array}$ & -0.033 & 0.056 & 0.193 & 0.314 & 0.479 & 0.571 & 0.474 & 0.280 & 0.041 \\
\hline Wages & $\begin{array}{l}\text { SEPH business sector } \\
\text { employment growth }(\mathrm{y} / \mathrm{y})\end{array}$ & -0.100 & -0.033 & 0.095 & 0.319 & 0.593 & 0.815 & 0.879 & 0.753 & 0.531 \\
\hline Output prices & GDP deflator momentum & -0.406 & -0.218 & -0.044 & 0.242 & 0.494 & 0.606 & 0.467 & 0.133 & -0.289 \\
\hline $\begin{array}{l}\text { Credit conditions } \\
\text { (inverse, starting } \\
\text { 2001Q4) }\end{array}$ & $\begin{array}{l}\text { real business investment } \\
\text { growth }\end{array}$ & 0.067 & 0.102 & 0.161 & 0.251 & 0.401 & 0.546 & 0.542 & 0.431 & 0.214 \\
\hline
\end{tabular}

Notes: BOS variables expressed as a balance of opinion, that is, the percentage of positive responses minus the percentage of negative responses. SEPH=Survey of Employment, Payrolls and Hours (SEPH data is available from 2001Q1 only, i.e., from 2002Q1 in year-over-year growth terms).

Table 2: Example of real-time data-the output gap (in per cent) (available estimates at different points in time)

Estimates of the output gap in projection rounds March 2007 to September 2008 at the Bank of Canada

\begin{tabular}{llllllllll} 
& Mar-07 & Jun-07 & Sep-07 & Dec-07 & Mar-08 & Jun-08 & Sep-08 \\
\hline 2007Q1 & 0.169 & 0.273 & 0.446 & 0.430 & 0.354 & 0.470 & 0.510 \\
2007Q2 & & 0.177 & 0.497 & 0.436 & 0.665 & 0.809 & 0.825 & More \\
2007Q3 & & & 0.491 & 0.574 & 0.900 & 1.094 & 1.093 & recent \\
2007Q4 & & & & 1.585 & 0.981 & 1.324 & 1.361 & periods \\
2008Q1 & & & & & 0.754 & 1.215 & 1.191 & $\downarrow$ \\
2008Q2 & & & & & & 0.727 & 0.184 & \\
2008Q3 & & & & & & & -0.520 \\
\hline
\end{tabular}

More recent vintages $\rightarrow$ 
Table 3: Summary statistics of nowcast and forecast errors of Taylor rule variables

\begin{tabular}{lccc}
\hline & $\begin{array}{c}\text { Output Gap, } \\
\text { nowcast }\end{array}$ & $\begin{array}{c}\text { Core Inflation Forecast, } \\
\text { 2-quarters-ahead }\end{array}$ & $\begin{array}{c}\text { Total Inflation Forecast, } \\
\text { 2-quarters-ahead }\end{array}$ \\
\cline { 2 - 4 } Mean & 0.546 & Nowcast/forecast error (200101-2015Q3) & \\
Absolute mean & 0.808 & 0.056 & 0.259 \\
Standard deviation & 1.142 & 0.648 & 1.545 \\
\hline
\end{tabular}

Table 4a: Real-time estimations à la Koenig et al. (2003) of the Taylor rule

\begin{tabular}{|c|c|c|c|c|c|c|}
\hline & \multicolumn{2}{|c|}{ Taylor rule } & \multicolumn{2}{|c|}{ Augmented Taylor rule } & \multicolumn{2}{|c|}{ Alternative Taylor rule } \\
\hline & $\begin{array}{l}\text { Backward- } \\
\text { looking }\end{array}$ & $\begin{array}{l}\text { Forward- } \\
\text { looking }\end{array}$ & $\begin{array}{l}\text { Backward- } \\
\text { looking }\end{array}$ & $\begin{array}{l}\text { Forward- } \\
\text { looking }\end{array}$ & $\begin{array}{l}\text { Backward- } \\
\text { looking }\end{array}$ & $\begin{array}{l}\text { Forward- } \\
\text { looking }\end{array}$ \\
\hline & $(1)$ & $(2)$ & (3) & (4) & $(5)$ & $(6)$ \\
\hline Overnight rate $_{t-1}$ & $\begin{array}{r}0.851 * * * \\
(0.051)\end{array}$ & $\begin{array}{r}0.874 * * * \\
(0.043)\end{array}$ & $\begin{array}{r}0.869 * * * \\
(0.043)\end{array}$ & $\begin{array}{r}0.883 * * * \\
(0.039)\end{array}$ & $\begin{array}{r}0.881^{* * *} \\
(0.039)\end{array}$ & $\begin{array}{r}0.892 * * * \\
(0.035)\end{array}$ \\
\hline Total Inflation ${ }_{t-1}-2$ & $\begin{array}{r}0.041 * * \\
(0.017)\end{array}$ & & $\begin{array}{r}-0.001 \\
(0.024)\end{array}$ & & $\begin{array}{r}-0.003 \\
(0.024)\end{array}$ & \\
\hline Core Inflation $_{t+2}-2$ & & $\begin{array}{r}0.359 * * \\
(0.155)\end{array}$ & & $\begin{array}{r}0.242 * * \\
(0.094)\end{array}$ & & $\begin{array}{r}0.255^{* * *} \\
(0.094)\end{array}$ \\
\hline BOS indicator $_{t-1}$ & & & $\begin{array}{r}0.242^{* * *} \\
(0.056)\end{array}$ & $\begin{array}{r}0.223^{* * *} \\
(0.038)\end{array}$ & $\begin{array}{r}0.271 * * * \\
(0.044)\end{array}$ & $\begin{array}{r}0.242 * * * \\
(0.03)\end{array}$ \\
\hline Output Gap & $\begin{array}{r}0.173^{* * *} \\
(0.065)\end{array}$ & $\begin{array}{r}0.154 * * * \\
(0.048)\end{array}$ & $\begin{array}{r}0.043 \\
(0.058)\end{array}$ & $\begin{array}{r}0.031 \\
(0.053)\end{array}$ & & \\
\hline C & $\begin{array}{c}0.345^{*} \\
(0.102) \\
\end{array}$ & $\begin{array}{r}0.349 * * * \\
(0.098) \\
\end{array}$ & $\begin{array}{r}0.215^{* *} \\
(0.105) \\
\end{array}$ & $\begin{array}{r}0.233 * * \\
(0.092) \\
\end{array}$ & $\begin{array}{r}0.164^{* *} \\
(0.078) \\
\end{array}$ & $\begin{array}{r}0.199 * * * \\
(0.073) \\
\end{array}$ \\
\hline Observations & 60 & 60 & 60 & 60 & 60 & 60 \\
\hline Adj. R-squared & 0.947 & 0.951 & 0.963 & 0.966 & 0.963 & 0.966 \\
\hline $\begin{array}{l}\text { Notes: HAC standar } \\
\text { Estimation sample: } \\
\text { inflation, while for } \\
\text { Taylor rule refers }\end{array}$ & $\begin{array}{l}\text { errors in parer } \\
\text { 2001Q1 to } 20 \\
\text { vard-looking Ta } \\
\text { specifications }\end{array}$ & $\begin{array}{l}\text { theses. } *, * *, * \\
6 Q 1 . \text { Standard } \\
\text { ylor rules use } \\
\text { including both }\end{array}$ & $\begin{array}{l}\text { * denote signif } \\
\text { backward-looki } \\
\text {-quarters-ahea } \\
\text { the output gar }\end{array}$ & $\begin{array}{l}\text { cance at the 10, } \\
\text { ig Taylor rules } \\
\text { forecasts of } \\
\text { and the BOS }\end{array}$ & $\begin{array}{l}5 \text { and } 1 \% \text { levels. } \\
\text { use last quarte } \\
\text { core inflation. T } \\
\text { ndicator, while }\end{array}$ & $\begin{array}{l}\text { 's actual total } \\
\text { he augmented } \\
\text { the alternative }\end{array}$ \\
\hline
\end{tabular}

\footnotetext{
${ }^{55}$ For the purpose of evaluating forecast/nowcast errors, we restrict the sample to exclude the last two available data points (2015Q4-2016Q1) because the data will still get revised.
} 
Table 4b: Real-time estimations à la Koenig et al. (2003) of the Taylor rule using an extended sample (1993Q4-2016Q1)

\begin{tabular}{|c|c|c|c|c|c|c|}
\hline & \multicolumn{2}{|c|}{ Standard Taylor rule } & \multicolumn{2}{|c|}{ Augmented Taylor rule } & \multicolumn{2}{|c|}{ Alternative Taylor rule } \\
\hline & $\begin{array}{l}\text { Backward- } \\
\text { looking }\end{array}$ & $\begin{array}{l}\text { Forward- } \\
\text { looking }\end{array}$ & $\begin{array}{l}\text { Backward- } \\
\text { looking }\end{array}$ & $\begin{array}{l}\text { Forward- } \\
\text { looking }\end{array}$ & $\begin{array}{l}\text { Backward- } \\
\text { looking }\end{array}$ & $\begin{array}{l}\text { Forward- } \\
\text { looking }\end{array}$ \\
\hline & $(1)$ & $(2)$ & (3) & (4) & $(5)$ & $(6)$ \\
\hline$i_{t-1}$ & $\begin{array}{r}0.973^{* * * *} \\
(0.033)\end{array}$ & $\begin{array}{r}0.976 * * * \\
(0.025)\end{array}$ & $\begin{array}{r}0.93 * * * \\
(0.023)\end{array}$ & $\begin{array}{r}0.936 * * * \\
(0.022)\end{array}$ & $\begin{array}{r}0.932^{* * *} \\
(0.026)\end{array}$ & $\begin{array}{r}0.937 * * * \\
(0.023)\end{array}$ \\
\hline$C P I_{t-1}-2$ & $\begin{array}{r}0.018 \\
(0.028)\end{array}$ & & $\begin{array}{r}-0.006 \\
(0.025)\end{array}$ & & $\begin{array}{r}-0.006 \\
(0.028)\end{array}$ & \\
\hline$C P I_{t+2^{-}}-2$ & & $\begin{array}{r}0.463 * * * \\
(0.159)\end{array}$ & & $\begin{array}{r}0.417 * * \\
(0.141)\end{array}$ & & $\begin{array}{r}0.417 * * * \\
(0.14)\end{array}$ \\
\hline$I B C_{t-1}$ & & & $\begin{array}{r}0.302 * * * \\
(0.078)\end{array}$ & $\begin{array}{r}0.283 * * * \\
(0.055)\end{array}$ & $\begin{array}{r}0.298 * * * \\
(0.061)\end{array}$ & $\begin{array}{r}0.277^{* * *} \\
(0.048)\end{array}$ \\
\hline Output $G_{a p}$ & $\begin{array}{r}0.042 \\
(0.051)\end{array}$ & $\begin{array}{r}0.043 \\
(0.042)\end{array}$ & $\begin{array}{r}-0.007 \\
(0.055)\end{array}$ & $\begin{array}{r}-0.009 \\
(0.043)\end{array}$ & & \\
\hline C & $\begin{array}{c}0.082 * \\
(0.088)\end{array}$ & $\begin{array}{r}0.186 * * \\
(0.072)\end{array}$ & $\begin{array}{r}0.081 * * \\
(0.076) \\
\end{array}$ & $\begin{array}{r}0.172 * * \\
(0.074)\end{array}$ & $\begin{array}{r}0.085^{* *} \\
(0.06) \\
\end{array}$ & $\begin{array}{r}0.178 * * * \\
(0.069)\end{array}$ \\
\hline Observations & 91 & 91 & 91 & 91 & 91 & 91 \\
\hline Adj. R-squared & 0.93 & 0.938 & 0.944 & 0.951 & 0.944 & 0.951 \\
\hline
\end{tabular}

Notes: HAC standard errors in parentheses. ${ }^{*}, * *, * * *$ denote significance at the 10,5 and $1 \%$ level. Estimation sample: 1993Q4 to 2016Q1. Standard/backward-looking Taylor rules use last quarter's actual total inflation, while forward-looking Taylor rules use 2-quarters-ahead forecasts of core inflation. The augmented Taylor rule refers to specifications including both the output gap and the IBC, while the alternative Taylor rule refers to the specification including the IBC instead of the output gap. 
Table 5: Forecast performance of different Taylor rule models

Forecast Accuracy Analysis

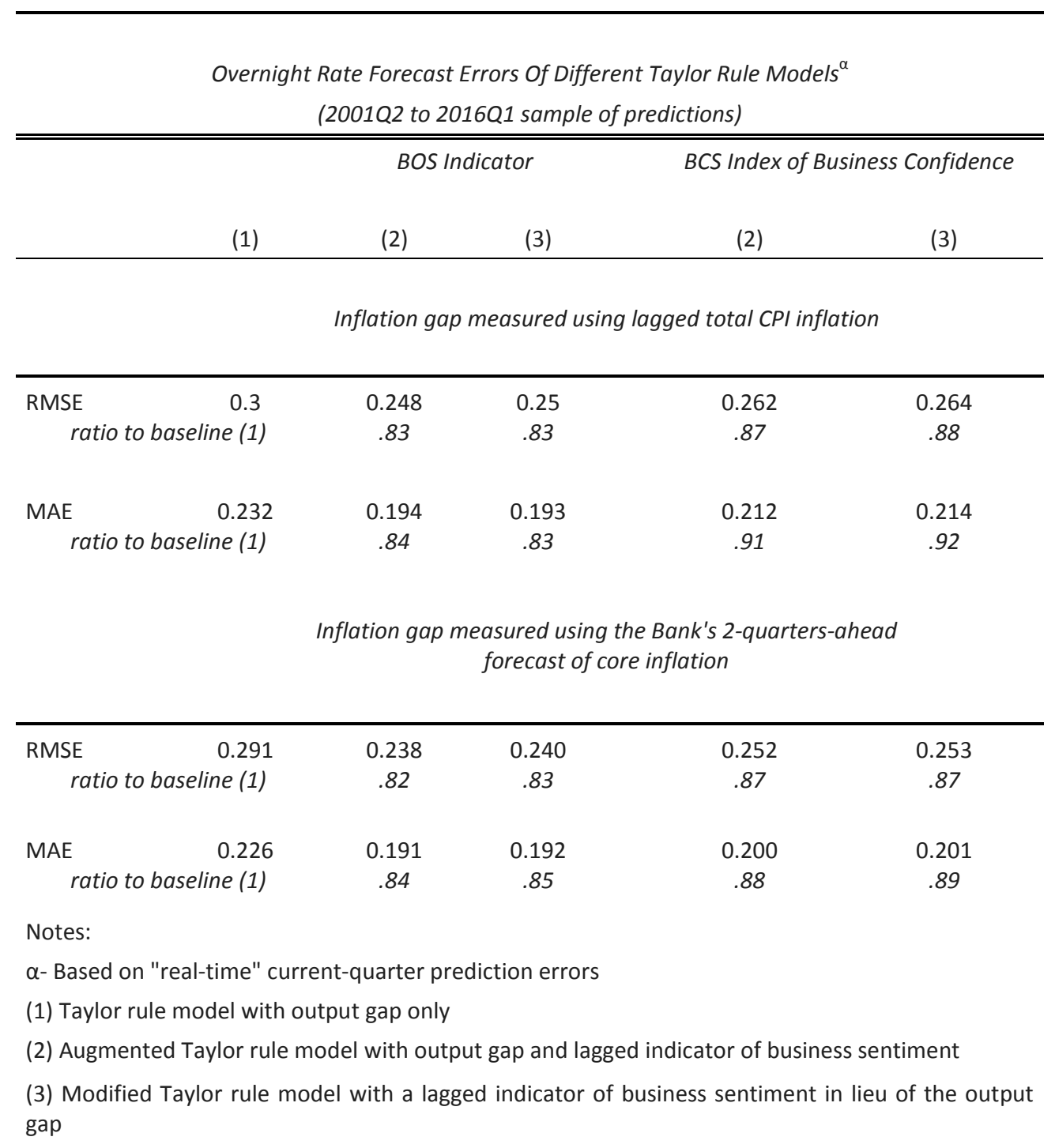


Table 6: Estimated impact of monetary policy shocks on firms' sales perspectives in an ordered logit regression (2001Q2-2016Q1)

$$
\text { Future_Sales }_{i t}=\gamma^{\prime} * X_{i t}+\varphi^{\prime} * \text { macro }_{t-1}+\emptyset_{s} * \sum_{i=0}^{i=s} \text { Monetary_Policy_shock }_{t-i}
$$

\begin{tabular}{|c|c|c|c|c|c|c|c|c|c|c|}
\hline \multirow[b]{2}{*}{ Sum of lags } & \multicolumn{5}{|c|}{ Contemporaneous Monetary Shocks } & \multicolumn{5}{|c|}{ "Exogenous" Monetary Shocks } \\
\hline & $\operatorname{Lag} 0$ & $\begin{array}{l}\text { Lag } 0 \text { to } \\
\text { Lag } 1\end{array}$ & $\begin{array}{l}\text { Lag } 0 \text { to } \\
\text { Lag } 2\end{array}$ & $\begin{array}{l}\text { Lag } 0 \text { to } \\
\operatorname{Lag} 3\end{array}$ & $\begin{array}{l}\text { Lag } 0 \text { to } \\
\text { Lag } 4\end{array}$ & Lag 5 & $\begin{array}{l}\text { Lag } 5 \text { to } \\
\text { Lag } 6\end{array}$ & $\begin{array}{l}\text { Lag } 5 \text { to } \\
\operatorname{Lag} 7\end{array}$ & $\begin{array}{l}\text { Lag } 5 \text { to } \\
\text { Lag } 8\end{array}$ & $\begin{array}{l}\text { Lag } 5 \text { to } \\
\text { Lag } 9\end{array}$ \\
\hline & \multicolumn{10}{|c|}{ Odds Ratios } \\
\hline Standard Taylor rule residuals & $\begin{array}{c}1.288^{* * *} \\
(0.114)\end{array}$ & $\begin{array}{c}1.067 \\
(0.0565)\end{array}$ & $\begin{array}{c}0.981 \\
(0.0374)\end{array}$ & $\begin{array}{l}0.950^{*} \\
(0.0291)\end{array}$ & $\begin{array}{l}0.936^{* *} \\
(0.0245)\end{array}$ & $\begin{array}{r}0.664^{* * *} \\
(0.0559)\end{array}$ & $\begin{array}{l}0.766^{* * *} \\
(0.0370)\end{array}$ & $\begin{array}{l}0.797^{* * *} \\
(0.0293)\end{array}$ & $\begin{array}{l}0.813^{* * *} \\
(0.0262)\end{array}$ & $\begin{array}{c}0.822^{* * *} \\
(0.0240)\end{array}$ \\
\hline $\begin{array}{l}\text { BOS Indicator: } \\
\text { Alternative Taylor rule residuals }\end{array}$ & $\begin{array}{c}1.307^{* * *} \\
(0.133)\end{array}$ & $\begin{array}{c}1.089 \\
(0.0683)\end{array}$ & $\begin{array}{c}1.027 \\
(0.0488)\end{array}$ & $\begin{array}{c}0.995 \\
(0.0397)\end{array}$ & $\begin{array}{c}0.958 \\
(0.0338)\end{array}$ & $\begin{array}{l}0.677^{* * *} \\
(0.0705)\end{array}$ & $\begin{array}{l}0.739 * * * \\
(0.0450)\end{array}$ & $\begin{array}{l}0.773^{* * *} \\
(0.0358)\end{array}$ & $\begin{array}{l}0.803^{* * *} \\
(0.0326)\end{array}$ & $\begin{array}{r}0.823^{* * *} \\
(0.0306)\end{array}$ \\
\hline $\begin{array}{l}\text { Index of Business Confidence: } \\
\text { Alternative Taylor rule residuals }\end{array}$ & $\begin{array}{c}1.156 \\
(0.110)\end{array}$ & $\begin{array}{c}0.999 \\
(0.0566)\end{array}$ & $\begin{array}{c}0.958 \\
(0.0416)\end{array}$ & $\begin{array}{c}0.954 \\
(0.0341)\end{array}$ & $\begin{array}{c}0.953 \\
(0.0298)\end{array}$ & $\begin{array}{l}0.760^{* * *} \\
(0.0768)\end{array}$ & $\begin{array}{l}0.803^{* * *} \\
(0.0451)\end{array}$ & $\begin{array}{l}0.829^{* * *} \\
(0.0350)\end{array}$ & $\begin{array}{l}0.842^{* * *} \\
(0.0308)\end{array}$ & $\begin{array}{l}0.836^{* * *} \\
(0.0282)\end{array}$ \\
\hline Observations & 5,974 & 5,910 & 5,811 & 5,717 & 5,618 & 5,523 & 5,425 & 5,325 & 5,225 & 5,126 \\
\hline Degrees of freedom & 18 & 18 & 18 & 18 & 18 & 18 & 18 & 18 & 18 & 18 \\
\hline Sector dummies & YES & YES & YES & YES & YES & YES & YES & YES & YES & YES \\
\hline Region dummies & YES & YES & YES & YES & YES & YES & YES & YES & YES & YES \\
\hline Quarter dummies & YES & YES & YES & YES & YES & YES & YES & YES & YES & YES \\
\hline Size dummies & YES & YES & YES & YES & YES & YES & YES & YES & YES & YES \\
\hline Macro controls & YES & YES & YES & YES & YES & YES & YES & YES & YES & YES \\
\hline
\end{tabular}

Notes: All Taylor rule estimations are done in real time à la Koenig et al. (2003). Standard Taylor rule residuals denote residuals obtained from estimating equation 1. Alternative Taylor rule residuals denote residuals obtained from estimating equation 1.1 excluding the output gap. Coefficients expressed as odds ratios with robust standard error in parentheses. $, * *, * * *$ denote significance at the 10,5 and $1 \%$ level. Macro controls include lagged real US and Canadian GDP growth (Q/Q, SAAR) and WTI oil price (USD) growth (Q/Q). 
Table 7: Estimated impact of monetary policy shocks on firms' future sales indicators in an ordered logit regression (2003Q3-2016Q1)

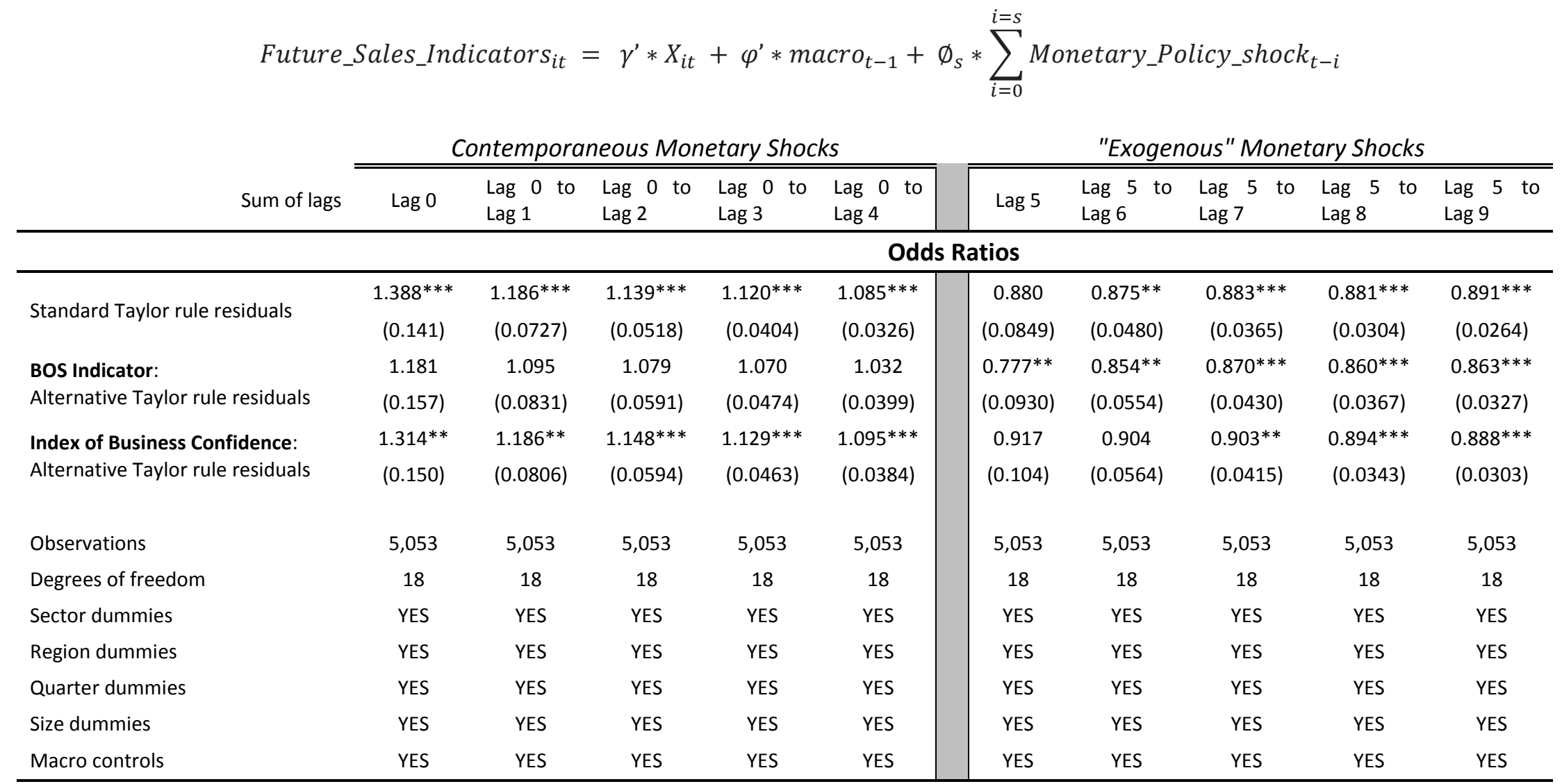

Notes: All Taylor rule estimations are done in real time à la Koenig et al. (2003). Standard Taylor rule residuals denote residuals obtained from estimating equation 1. Alternative Taylor rule residuals denote residuals obtained from estimating equation 1.1 excluding the output gap. Coefficients expressed as odds ratios with robust standard error in parentheses. *,***** denote significance at the 10, 5 and $1 \%$ level. Macro controls include lagged real US and Canadian GDP growth (Q/Q, SAAR) and WTI oil price (USD) growth (Q/Q). 
Table 8: Estimated impact of monetary policy shocks on firms' credit conditions in an ordered logit regression (2001Q2-2016Q1)

\begin{tabular}{|c|c|c|c|c|c|c|c|c|c|c|}
\hline & \multicolumn{5}{|c|}{ Contemporaneous Monetary Shocks } & \multicolumn{5}{|c|}{ "Exogenous" Monetary Shocks } \\
\hline Sum of lags & $\operatorname{Lag} 0$ & $\begin{array}{l}\text { Lag } 0 \text { to } \\
\text { Lag } 1\end{array}$ & $\begin{array}{l}\text { Lag } 0 \text { to } \\
\text { Lag } 2\end{array}$ & $\begin{array}{l}\text { Lag } 0 \text { to } \\
\text { Lag } 3\end{array}$ & $\begin{array}{l}\text { Lag } 0 \text { to } \\
\text { Lag } 4\end{array}$ & Lag 5 & $\begin{array}{l}\operatorname{Lag} 5 \text { to } \\
\operatorname{Lag} 6\end{array}$ & $\begin{array}{l}\operatorname{Lag} 5 \text { to } \\
\operatorname{Lag} 7\end{array}$ & $\begin{array}{l}\text { Lag } 5 \text { to } \\
\text { Lag } 8\end{array}$ & $\begin{array}{l}\text { Lag } 5 \text { to } \\
\operatorname{Lag} 9\end{array}$ \\
\hline & \multicolumn{10}{|c|}{ Odds Ratios } \\
\hline Standard Taylor rule residuals & $\begin{array}{l}0.578^{* * *} \\
(0.0641)\end{array}$ & $\begin{array}{l}0.684^{* * *} \\
(0.0447)\end{array}$ & $\begin{array}{r}0.764^{* * *} \\
(0.0368)\end{array}$ & $\begin{array}{r}0.811^{* * *} \\
(0.0316)\end{array}$ & $\begin{array}{l}0.871^{* * *} \\
(0.0289)\end{array}$ & $\begin{array}{c}1.169 \\
(0.120)\end{array}$ & $\begin{array}{l}1.121^{* *} \\
(0.0651)\end{array}$ & $\begin{array}{l}1.142^{* * *} \\
(0.0516)\end{array}$ & $\begin{array}{l}1.157^{* * *} \\
(0.0452)\end{array}$ & $\begin{array}{r}1.198^{* * *} \\
(0.0433)\end{array}$ \\
\hline $\begin{array}{l}\text { BOS Indicator: } \\
\text { Alternative Taylor rule residuals }\end{array}$ & $\begin{array}{c}1.212 \\
(0.159)\end{array}$ & $\begin{array}{c}1.013 \\
(0.0804)\end{array}$ & $\begin{array}{c}0.937 \\
(0.0562)\end{array}$ & $\begin{array}{c}0.953 \\
(0.0480)\end{array}$ & $\begin{array}{c}1.015 \\
(0.0451)\end{array}$ & $\begin{array}{c}1.522^{* * *} \\
(0.203)\end{array}$ & $\begin{array}{l}1.278^{* * *} \\
(0.0962)\end{array}$ & $\begin{array}{l}1.192^{* * *} \\
(0.0676)\end{array}$ & $\begin{array}{l}1.181^{* * *} \\
(0.0577)\end{array}$ & $\begin{array}{l}1.219^{* * *} \\
(0.0545)\end{array}$ \\
\hline $\begin{array}{l}\text { Index of Business Confidence: } \\
\text { Alternative Taylor rule residuals }\end{array}$ & $\begin{array}{c}0.942 \\
(0.109)\end{array}$ & $\begin{array}{c}0.905 \\
(0.0620)\end{array}$ & $\begin{array}{l}0.870^{* * *} \\
(0.0465)\end{array}$ & $\begin{array}{l}0.879^{* * *} \\
(0.0395)\end{array}$ & $\begin{array}{l}0.911^{* *} \\
(0.0359)\end{array}$ & $\begin{array}{c}1.085 \\
(0.140)\end{array}$ & $\begin{array}{c}1.114 \\
(0.0793)\end{array}$ & $\begin{array}{l}1.131^{* *} \\
(0.0612)\end{array}$ & $\begin{array}{l}1.134^{* * *} \\
(0.0520)\end{array}$ & $\begin{array}{l}1.181^{* * *} \\
(0.0501)\end{array}$ \\
\hline Observations & 4,819 & 4,773 & 4,694 & 4,616 & 4,546 & 4,466 & 4,392 & 4,314 & 4,234 & 4,151 \\
\hline Degrees of freedom & 18 & 18 & 18 & 18 & 18 & 18 & 18 & 18 & 18 & 18 \\
\hline Sector dummies & YES & YES & YES & YES & YES & YES & YES & YES & YES & YES \\
\hline Region dummies & YES & YES & YES & YES & YES & YES & YES & YES & YES & YES \\
\hline Quarter dummies & YES & YES & YES & YES & YES & YES & YES & YES & YES & YES \\
\hline Size dummies & YES & YES & YES & YES & YES & YES & YES & YES & YES & YES \\
\hline Macro controls & YES & YES & YES & YES & YES & YES & YES & YES & YES & YES \\
\hline
\end{tabular}

Notes: Standard Taylor rule residuals denote residuals obtained from estimating equation 1. Alternative Taylor rule residuals denote residuals obtained from estimating equation 1.1 excluding the output gap. Coefficients expressed as odds ratios with robust standard error in parentheses. $*, * *, * * *$ denote significance at the 10,5 and $1 \%$ level. Macro controls include lagged real US and Canadian GDP growth (Q/Q, SAAR) and WTI oil price (USD) growth (Q/Q). 
Table 9: Estimated impact of monetary policy shocks on firms' output price perspectives in an ordered logit regression (2001Q2-2016Q1)

$$
\text { Output Price growth } \text { grt }^{\prime}=\gamma^{\prime} * X_{i t}+\varphi^{\prime} * \text { macro }_{t-1}+\emptyset_{s} * \sum_{i=0}^{i=s} \text { Monetary_Policy_shock }_{t-i}
$$

\begin{tabular}{|c|c|c|c|c|c|c|c|c|c|c|}
\hline \multirow[b]{2}{*}{ Sum of lags } & \multicolumn{5}{|c|}{ Contemporaneous Monetary Shocks } & \multicolumn{5}{|c|}{ "Exogenous" Monetary Shocks } \\
\hline & $\operatorname{Lag} 0$ & $\begin{array}{l}\text { Lag } 0 \text { to } \\
\text { Lag } 1\end{array}$ & $\begin{array}{l}\text { Lag } 0 \text { to } \\
\text { Lag } 2\end{array}$ & $\begin{array}{l}\text { Lag } 0 \text { to } \\
\text { Lag } 3\end{array}$ & $\begin{array}{l}\operatorname{Lag} 0 \text { to } \\
\operatorname{Lag} 4\end{array}$ & Lag 5 & $\begin{array}{l}\text { Lag } 5 \text { to } \\
\text { Lag } 6\end{array}$ & $\begin{array}{l}\text { Lag } 5 \text { to } \\
\text { Lag } 7\end{array}$ & $\begin{array}{l}\text { Lag } 5 \text { to } \\
\text { Lag } 8\end{array}$ & $\begin{array}{l}\operatorname{Lag} 5 \text { to } \\
\operatorname{Lag} 9\end{array}$ \\
\hline & \multicolumn{10}{|c|}{ Odds Ratios } \\
\hline Standard Taylor rule residuals & $\begin{array}{c}1.064 \\
(0.0958)\end{array}$ & $\begin{array}{c}1.062 \\
(0.0562)\end{array}$ & $\begin{array}{c}1.047 \\
(0.0405)\end{array}$ & $\begin{array}{c}1.037 \\
(0.0326)\end{array}$ & $\begin{array}{c}1.007 \\
(0.0272)\end{array}$ & $\begin{array}{l}0.847^{* *} \\
(0.0705)\end{array}$ & $\begin{array}{c}0.863^{* * *} \\
(0.041)\end{array}$ & $\begin{array}{l}0.862^{* * *} \\
(0.0309)\end{array}$ & $\begin{array}{l}0.873^{* * *} \\
(0.0273)\end{array}$ & $\begin{array}{r}0.867 * * * \\
(0.0248)\end{array}$ \\
\hline $\begin{array}{l}\text { BOS Indicator: } \\
\text { Alternative Taylor rule residuals }\end{array}$ & $\begin{array}{c}1.094 \\
(0.113)\end{array}$ & $\begin{array}{l}1.124^{*} \\
(0.0697)\end{array}$ & $\begin{array}{l}1.126^{* *} \\
(0.0536)\end{array}$ & $\begin{array}{l}1.087^{* *} \\
(0.0436)\end{array}$ & $\begin{array}{c}1.03 \\
(0.0362)\end{array}$ & $\begin{array}{l}0.785^{* *} \\
(0.0786)\end{array}$ & $\begin{array}{l}0.834^{* * *} \\
(0.0501)\end{array}$ & $\begin{array}{l}0.840^{* * *} \\
(0.0381)\end{array}$ & $\begin{array}{l}0.850^{* * *} \\
(0.0339)\end{array}$ & $\begin{array}{l}0.838^{* * *} \\
(0.0305)\end{array}$ \\
\hline $\begin{array}{l}\text { Index of Business Confidence: } \\
\text { Alternative Taylor rule residuals }\end{array}$ & $\begin{array}{c}1.035 \\
(0.101)\end{array}$ & $\begin{array}{c}1.06 \\
(0.0598)\end{array}$ & $\begin{array}{c}1.05 \\
(0.0454)\end{array}$ & $\begin{array}{c}1.027 \\
(0.037)\end{array}$ & $\begin{array}{c}0.993 \\
(0.0314)\end{array}$ & $\begin{array}{c}0.758^{* * *} \\
(0.077)\end{array}$ & $\begin{array}{l}0.826^{* * *} \\
(0.0463)\end{array}$ & $\begin{array}{c}0.860^{* * *} \\
(0.036)\end{array}$ & $\begin{array}{l}0.881^{* * *} \\
(0.0317)\end{array}$ & $\begin{array}{l}0.879 * * * \\
(0.0291)\end{array}$ \\
\hline Observations & 5,955 & 5,890 & 5,791 & 5,697 & 5,598 & 5,503 & 5,405 & 5,306 & 5,206 & 5,107 \\
\hline Degrees of freedom & 18 & 18 & 18 & 18 & 18 & 18 & 18 & 18 & 18 & 18 \\
\hline Sector dummies & YES & YES & YES & YES & YES & YES & YES & YES & YES & YES \\
\hline Region dummies & YES & YES & YES & YES & YES & YES & YES & YES & YES & YES \\
\hline Quarter dummies & YES & YES & YES & YES & YES & YES & YES & YES & YES & YES \\
\hline Size dummies & YES & YES & YES & YES & YES & YES & YES & YES & YES & YES \\
\hline Macro controls & YES & YES & YES & YES & YES & YES & YES & YES & YES & YES \\
\hline
\end{tabular}

Notes: Standard Taylor rule residuals denote residuals obtained from estimating equation 1 . Alternative Taylor rule residuals denote residuals obtained from estimating equation 1.1 excluding the output gap. Coefficients expressed as odds ratios with robust standard error in parentheses. $*, * * * * *$ denote significance at the 10,5 and $1 \%$ level. Macro controls include lagged real US and Canadian GDP growth (Q/Q, SAAR) and WTI oil price (USD) growth (Q/Q). 
Table 10: Estimated impact of monetary policy shocks on firms' wage growth perspectives in an ordered logit regression (2001Q2-2016Q1)

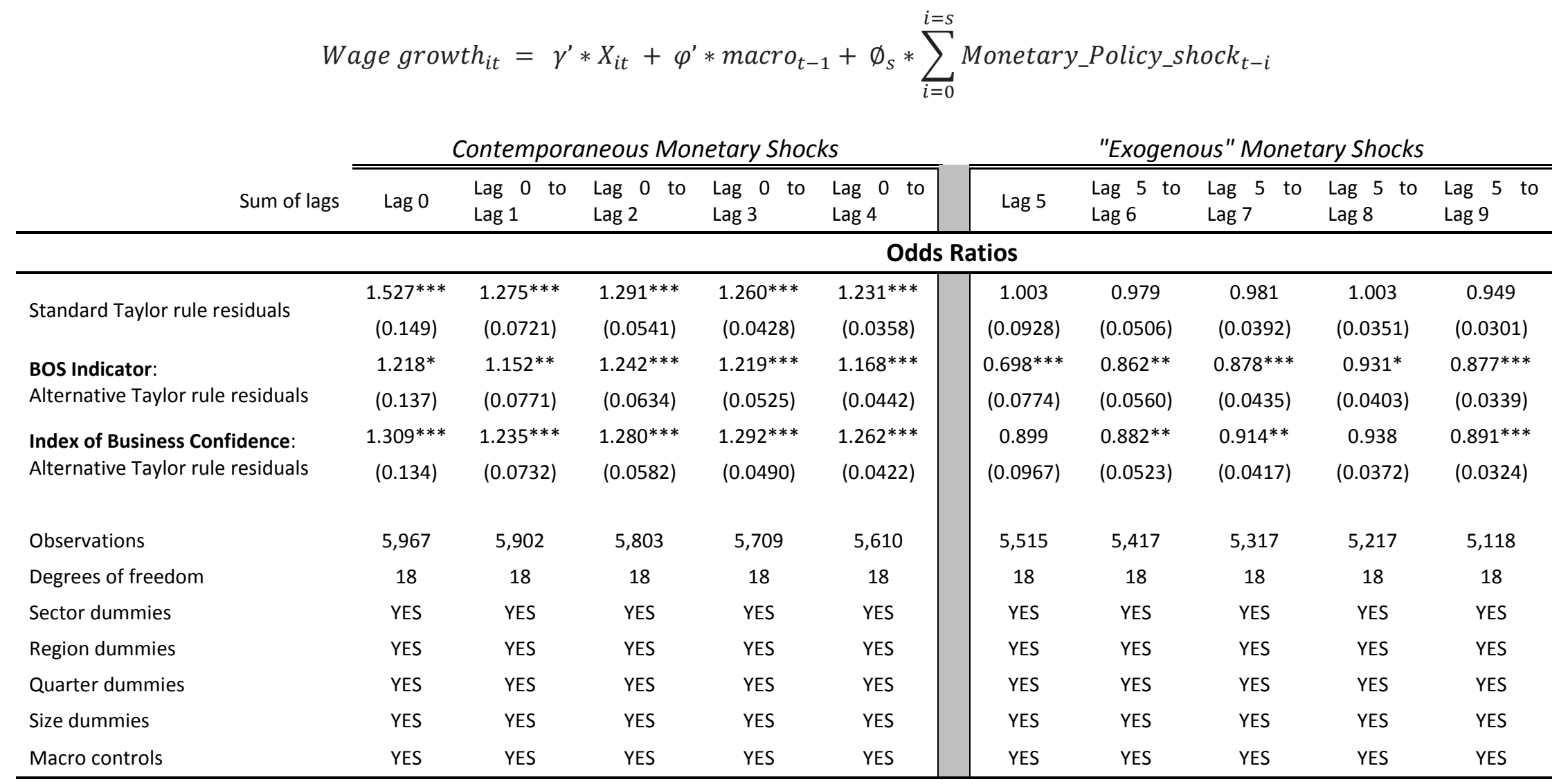

Notes: Standard Taylor rule residuals denote residuals obtained from estimating equation 1 . Alternative Taylor rule residuals denote residuals obtained from estimating equation 1.1 excluding the output gap. Coefficients expressed as odds ratios with robust standard error in parentheses. *,**,** denote significance at the 10,5 and $1 \%$ level. Macro controls include lagged real US and Canadian GDP growth (Q/Q, SAAR) and WTI oil price (USD) growth (Q/Q). 
Table 11: Estimated impact of monetary policy shocks on firms' investment intentions in an ordered logit regression (2001Q2-2016Q1)

\begin{tabular}{|c|c|c|c|c|c|c|c|c|c|c|c|}
\hline \multirow[b]{2}{*}{ Sum of lags } & \multicolumn{5}{|c|}{ Contemporaneous Monetary Shocks } & \multicolumn{6}{|c|}{ "Exogenous" Monetary Shocks } \\
\hline & $\operatorname{Lag} 0$ & $\begin{array}{l}\operatorname{Lag} 0 \text { to } \\
\operatorname{Lag} 1\end{array}$ & $\begin{array}{l}\operatorname{Lag} 0 \text { to } \\
\operatorname{Lag} 2\end{array}$ & $\begin{array}{l}\operatorname{Lag} 0 \text { to } \\
\operatorname{Lag} 3\end{array}$ & $\begin{array}{l}\operatorname{Lag} 0 \text { to } \\
\operatorname{Lag} 4\end{array}$ & Lag 5 & $\begin{array}{l}\operatorname{Lag} 5 \text { to } \\
\operatorname{Lag} 6\end{array}$ & $\ldots$ & $\begin{array}{l}\operatorname{Lag} 5 \text { to } \\
\operatorname{Lag} 10\end{array}$ & $\begin{array}{l}\text { Lag } 5 \text { to } \\
\text { Lag } 11\end{array}$ & $\begin{array}{l}\text { Lag } 5 \text { to } \\
\operatorname{Lag} 12\end{array}$ \\
\hline & \multicolumn{11}{|c|}{ Odds Ratios } \\
\hline Standard Taylor rule residuals & $\begin{array}{c}1.351^{* * *} \\
(0.120)\end{array}$ & $\begin{array}{l}1.183^{* * *} \\
(0.0624)\end{array}$ & $\begin{array}{l}1.127^{* * *} \\
(0.0438)\end{array}$ & $\begin{array}{l}1.087^{* * *} \\
(0.0343)\end{array}$ & $\begin{array}{l}1.064^{* *} \\
(0.0289)\end{array}$ & $\begin{array}{c}1.176^{*} \\
(0.0973)\end{array}$ & $\begin{array}{c}1.068 \\
(0.0499)\end{array}$ & $\ldots$ & $\begin{array}{c}0.968 \\
(0.0249)\end{array}$ & $\begin{array}{l}0.952^{* *} \\
(0.0228)\end{array}$ & $\begin{array}{l}0.937^{* * *} \\
(0.0219)\end{array}$ \\
\hline $\begin{array}{l}\text { BOS Indicator: } \\
\text { Alternative Taylor rule residuals }\end{array}$ & $\begin{array}{c}1.034 \\
(0.105)\end{array}$ & $\begin{array}{c}1.021 \\
(0.0632)\end{array}$ & $\begin{array}{c}1.049 \\
(0.0500)\end{array}$ & $\begin{array}{c}1.031 \\
(0.0416)\end{array}$ & $\begin{array}{c}1.003 \\
(0.0357)\end{array}$ & $\begin{array}{c}0.921 \\
(0.0956)\end{array}$ & $\begin{array}{c}0.979 \\
(0.0589)\end{array}$ & $\ldots$ & $\begin{array}{l}0.920^{* *} \\
(0.0320)\end{array}$ & $\begin{array}{l}0.915^{* * *} \\
(0.0307)\end{array}$ & $\begin{array}{l}0.910^{* * *} \\
(0.0299)\end{array}$ \\
\hline $\begin{array}{l}\text { Index of Business Confidence: } \\
\text { Alternative Taylor rule residuals }\end{array}$ & $\begin{array}{c}1.137 \\
(0.110)\end{array}$ & $\begin{array}{c}1.087 \\
(0.0622)\end{array}$ & $\begin{array}{l}1.077^{*} \\
(0.0477)\end{array}$ & $\begin{array}{c}1.050 \\
(0.0385)\end{array}$ & $\begin{array}{c}1.038 \\
(0.0334)\end{array}$ & $\begin{array}{c}1.151 \\
(0.119)\end{array}$ & $\begin{array}{c}1.041 \\
(0.0592)\end{array}$ & $\ldots$ & $\begin{array}{l}0.945^{*} \\
(0.0292)\end{array}$ & $\begin{array}{l}0.925^{* * *} \\
(0.0275)\end{array}$ & $\begin{array}{l}0.897^{* * *} \\
(0.0268)\end{array}$ \\
\hline Observations & 5,918 & 5,855 & 5,757 & 5,664 & 5,566 & 5,475 & 5,382 & & 4,998 & 4,899 & 4,799 \\
\hline Degrees of freedom & 18 & 18 & 18 & 18 & 18 & 18 & 18 & & 18 & 18 & 18 \\
\hline Sector dummies & YES & YES & YES & YES & YES & YES & YES & & YES & YES & YES \\
\hline Region dummies & YES & YES & YES & YES & YES & YES & YES & & YES & YES & YES \\
\hline Quarter dummies & YES & YES & YES & YES & YES & YES & YES & & YES & YES & YES \\
\hline Size dummies & YES & YES & YES & YES & YES & YES & YES & & YES & YES & YES \\
\hline Macro controls & YES & YES & YES & YES & YES & YES & YES & & YES & YES & YES \\
\hline
\end{tabular}

Notes: Standard Taylor rule residuals denote residuals obtained from estimating equation 1. Alternative Taylor rule residuals denote residuals obtained from estimating equation 1.1 excluding the output gap. Coefficients expressed as odds ratios with robust standard error in parentheses. *,**,*** denote significance at the 10,5 and $1 \%$ level. Macro controls include lagged real US and Canadian GDP growth (Q/Q, SAAR) and WTI oil price (USD) growth (Q/Q). 


\section{Charts}

Chart 1 : Example: vintages of estimated output gap during the Great Recession

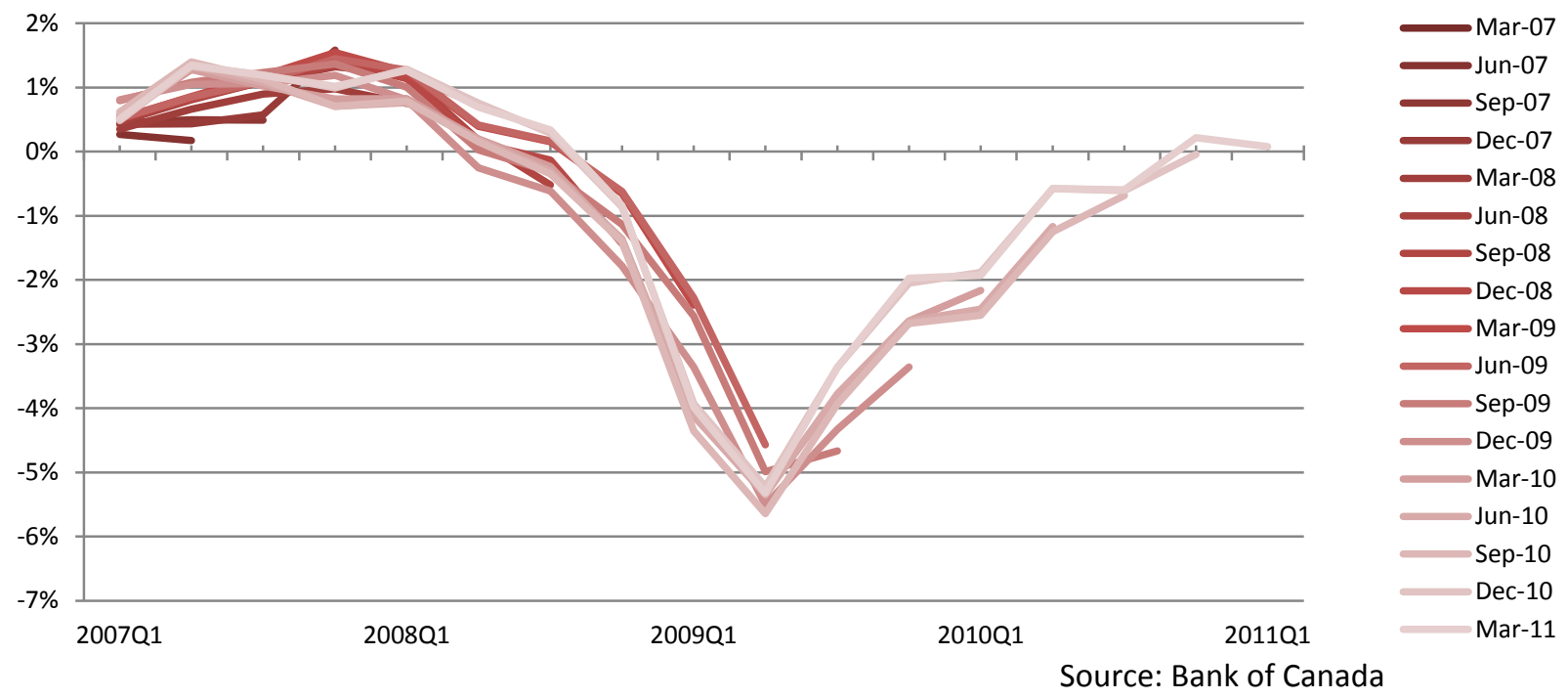

Chart 2: Example: vintages of forecasts of core inflation during the Great Recession

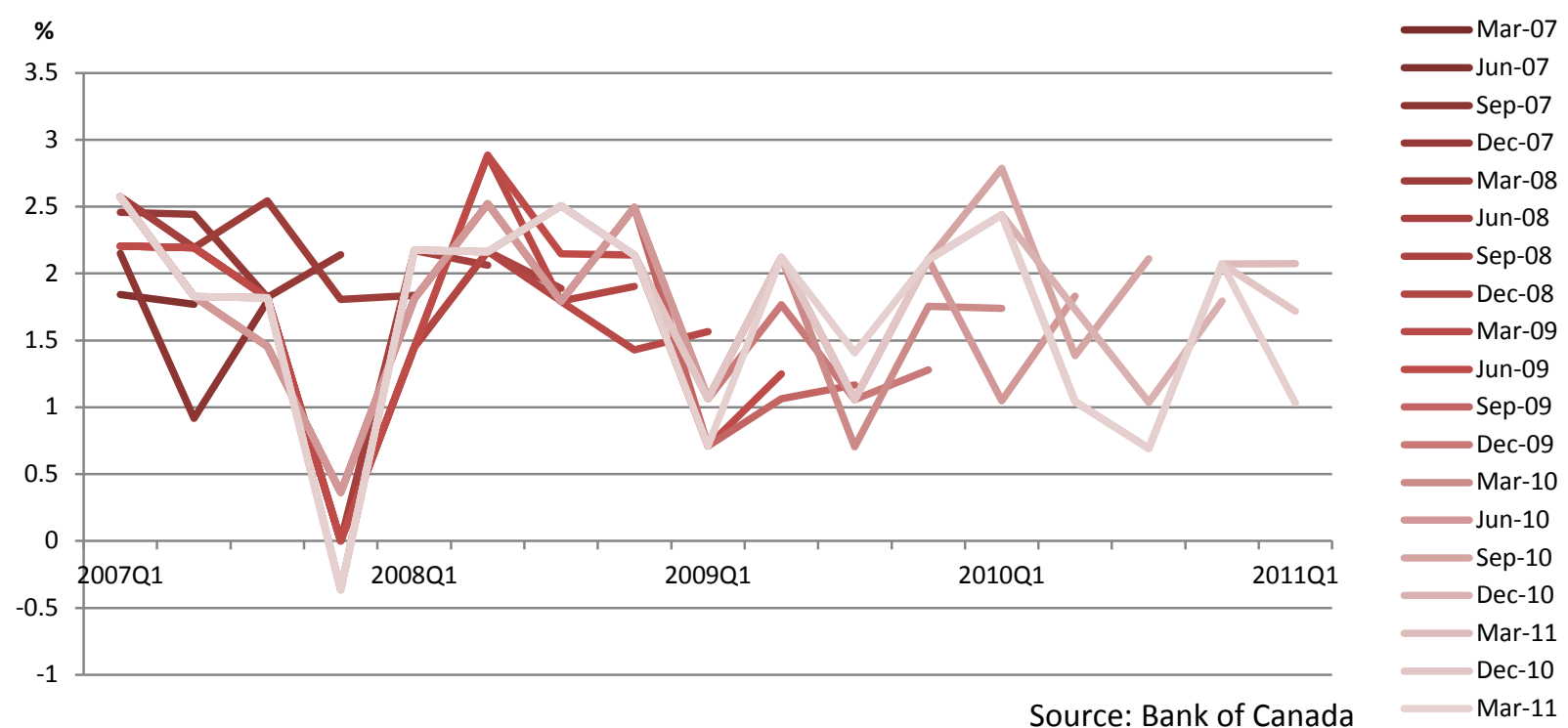


Chart 3: Real-time estimated coefficients of lagged overnight rate in a standard Taylor rule: à la Stark and Croushore or à la Koenig et al.

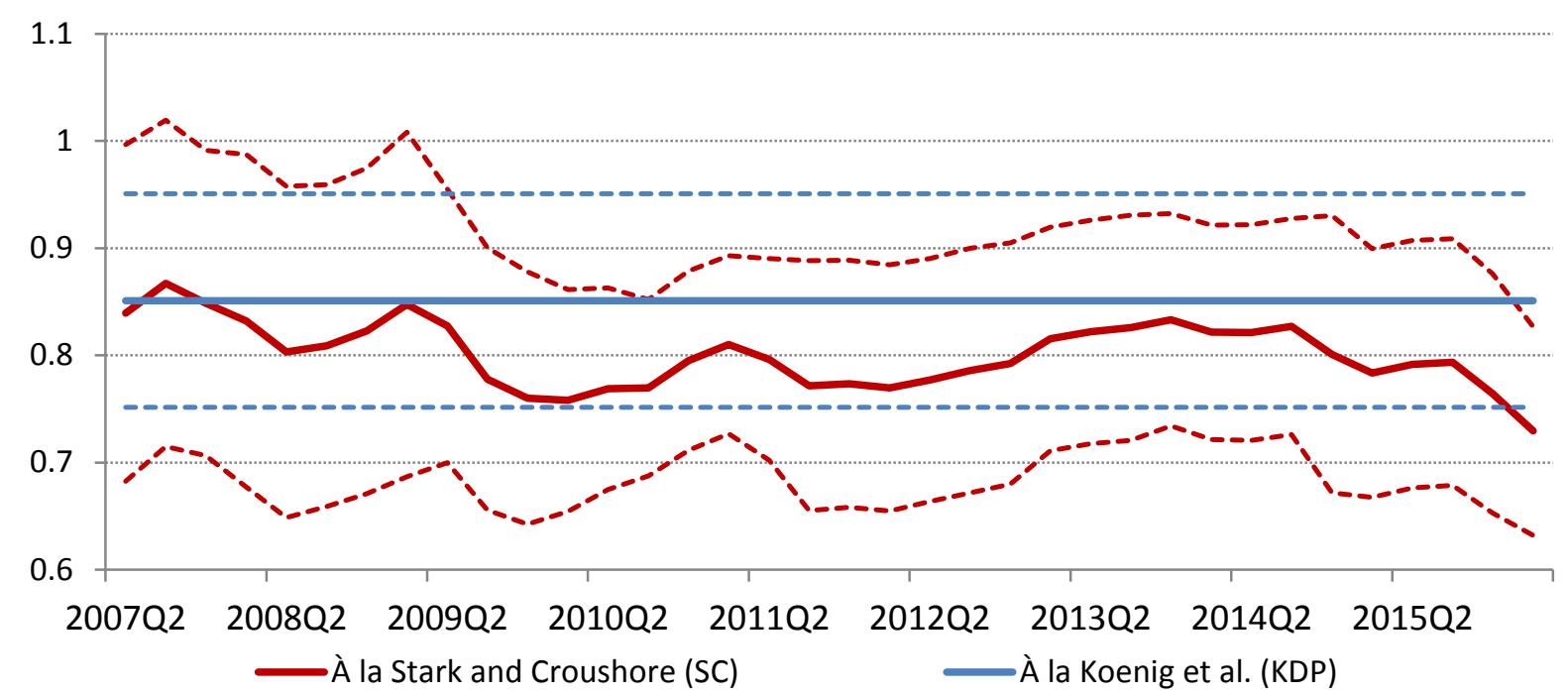

Notes: 1) Estimation samples: from 2001Q2 to date indicated on $\mathrm{x}$-axis for estimations à la SC; from $2001 \mathrm{Q} 2$ to $2016 \mathrm{Q} 2$ using first estimates for estimations à la KDP. 2) Dotted lines refer to $95 \%$ confidence intervals.

Chart 4: Real-time estimated coefficients of the output gap in a standard Taylor rule: à la Stark and Croushore or à la Koenig et al.

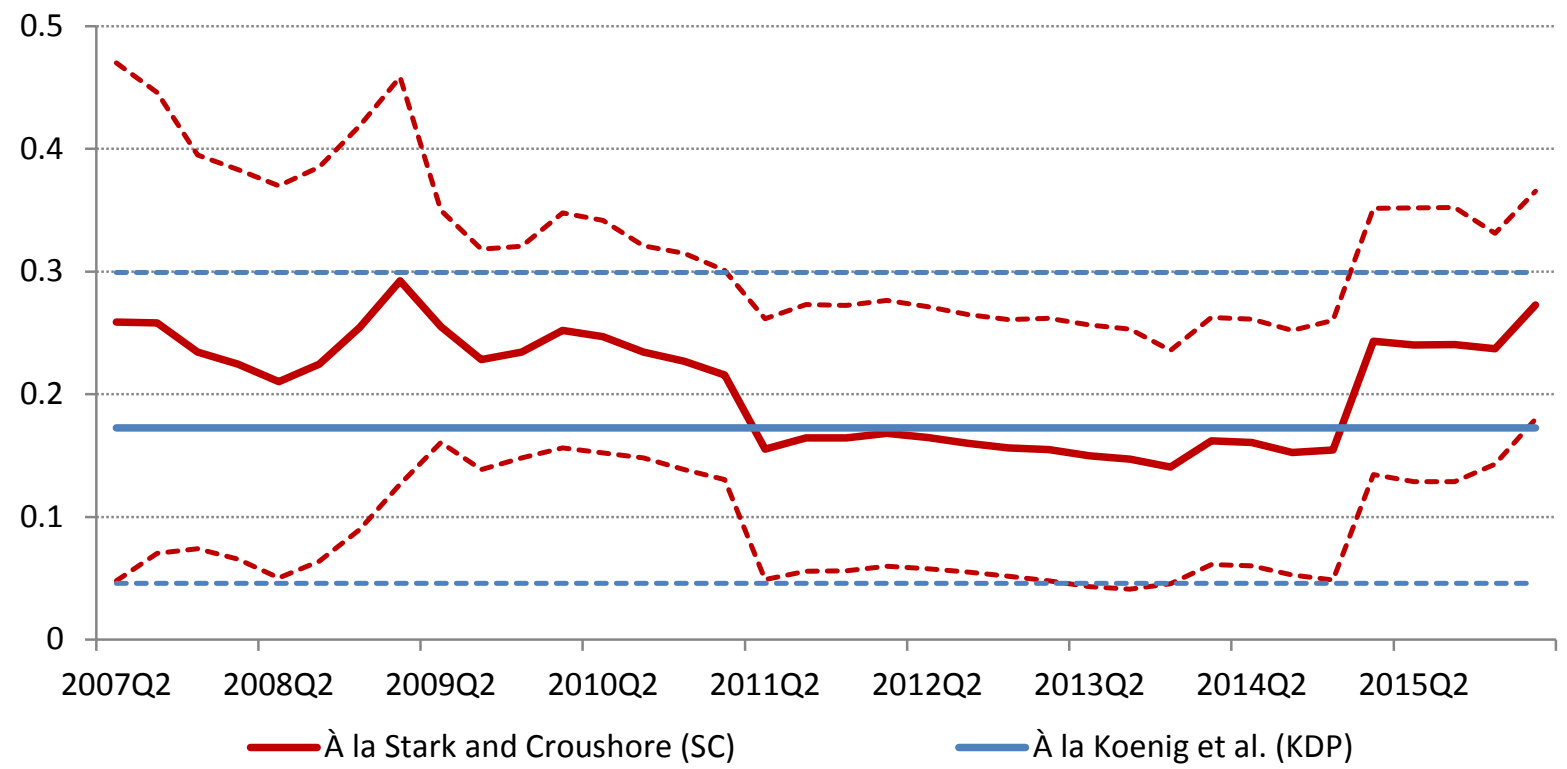

Notes: 1) Estimation samples: from 2001Q2 to date indicated on $\mathrm{x}$-axis for estimations à la SC; from $2001 \mathrm{Q} 2$ to2016Q2 using first estimates for estimations à la KDP. 2) Dotted lines refer to $95 \%$ confidence intervals. 
Chart 5: Real-time estimated coefficients of the "inflation gap" in a standard Taylor rule: à la Stark and Croushore or à la Koenig et al.

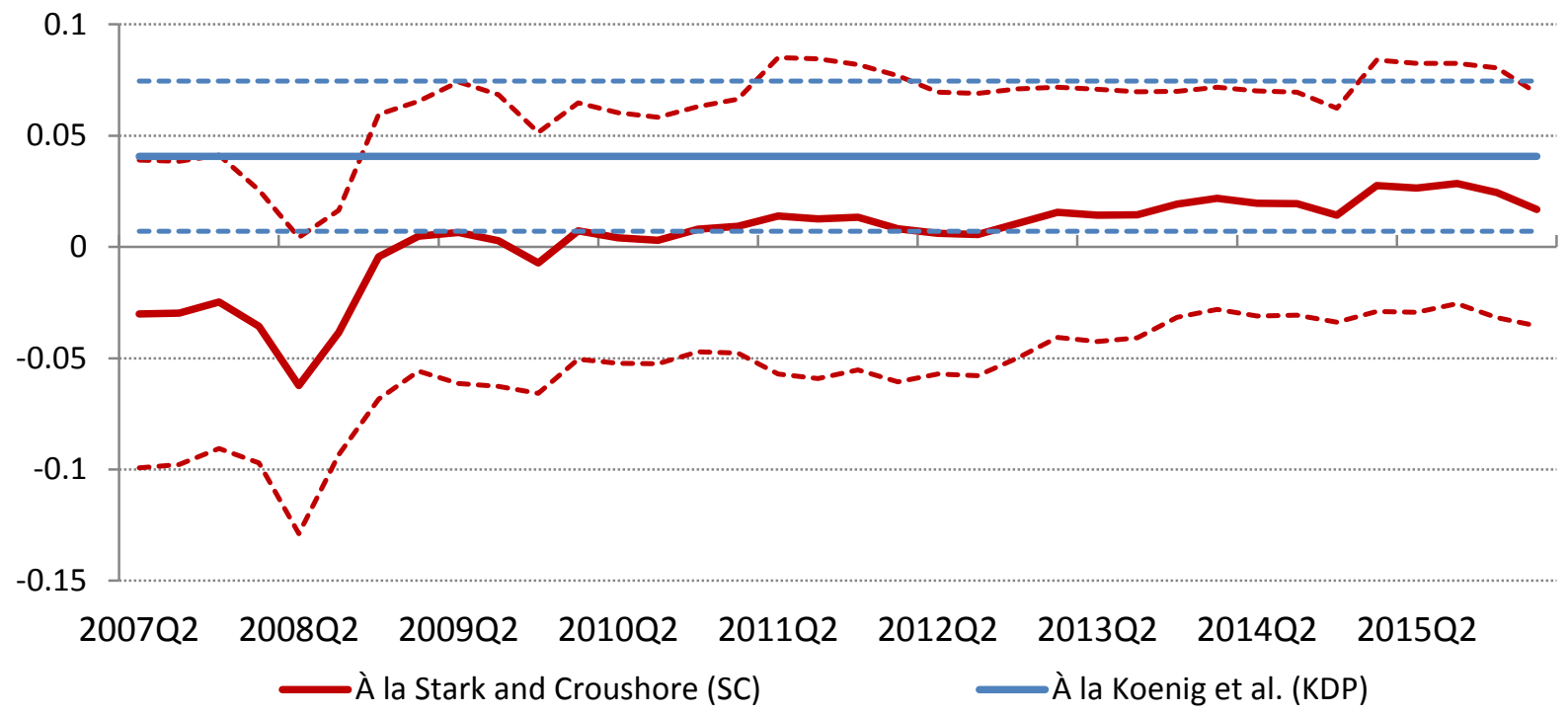

Notes: 1) Estimation samples: from 2001Q2 to date indicated on $\mathrm{x}$-axis for estimations à la SC; from $2001 \mathrm{Q} 2$ to 20 first estimates for estimations à la KDP. 2) Dotted lines refer to $95 \%$ confidence intervals. 3) "Inflation gap" measu difference of lagged total inflation and inflation target.

\section{Chart 6: Comparison of predicted Taylor rule policy rates, based on real-time analysis à la Koenig et} al. (2003)

(Current quarter predictions done à la Koenig et al. (2003) using real-time vintage data available at the time of the monetary policy decision)

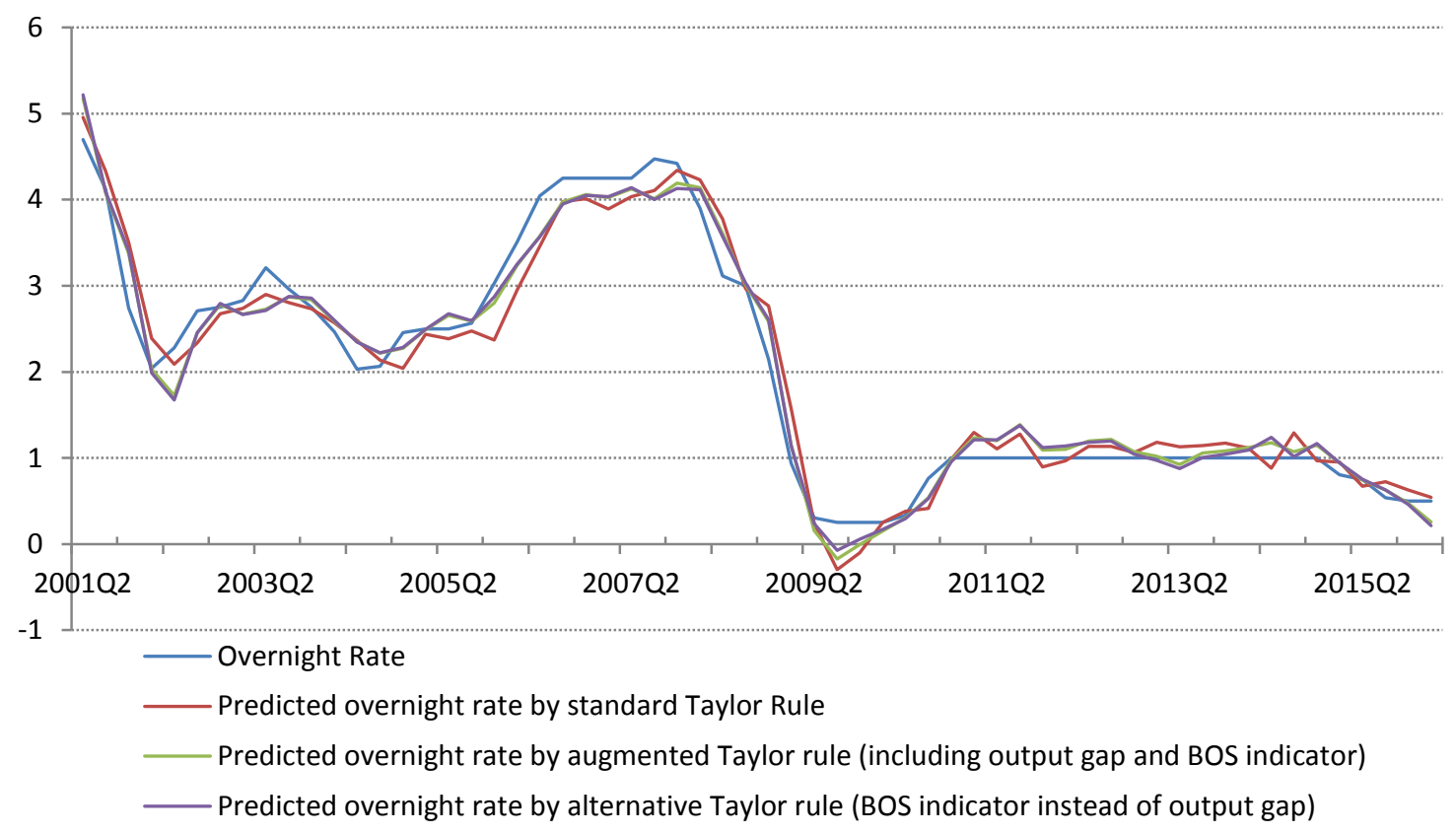


Chart 7: Definition of contemporaneous and exogenous monetary shocks relative to a typical forward-looking BOS variable

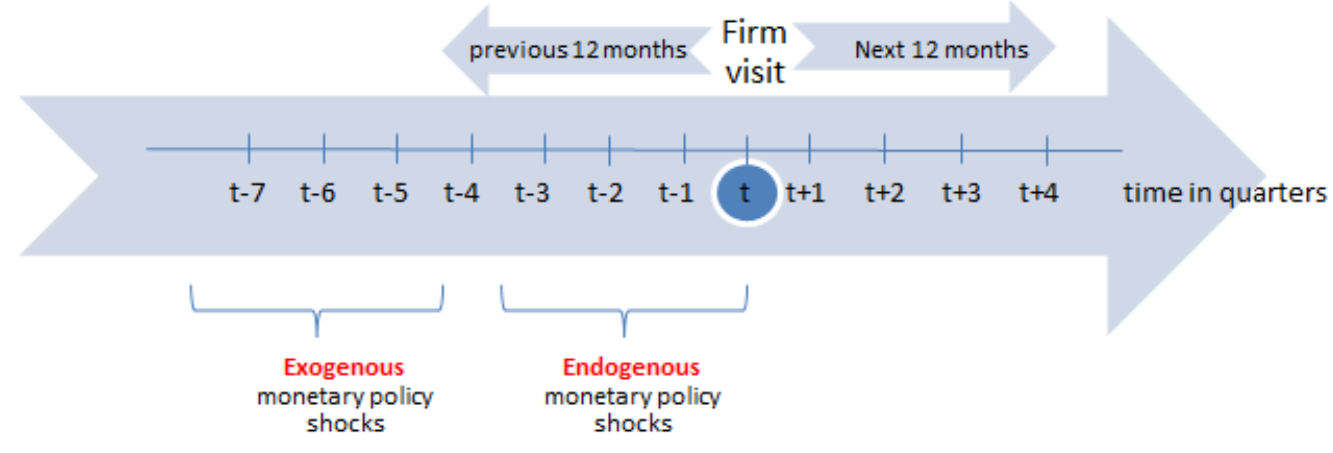

Chart 8: Accumulated response of future sales (balance of opinion) to alternative monetary policy shock-Index of Business Confidence replaces output gap in the monetary feedback rule

Accumulated Response to Cholesky One S.D. Innovations \pm 2 S.E.

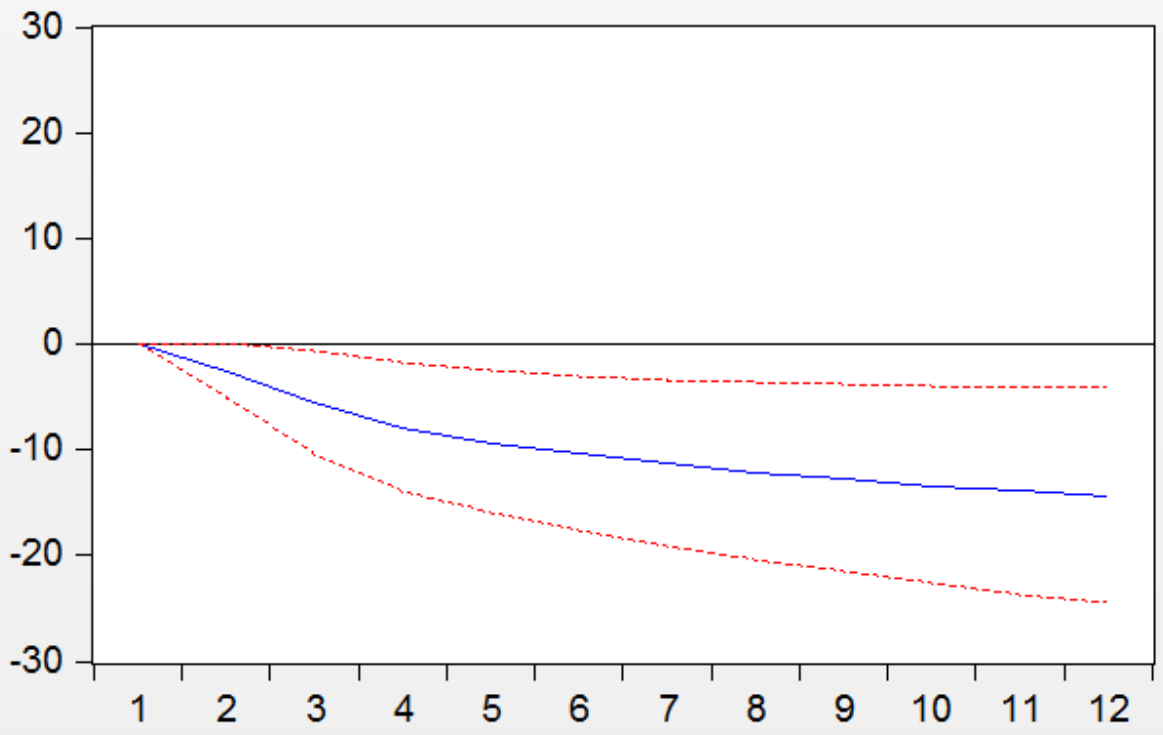


Chart 9: Accumulated response of indicators of future sales (balance of opinion) to alternative monetary policy shock-Index of Business Confidence replaces output gap in the monetary feedback rule

Accumulated Response to Cholesky One S.D. Innovations \pm 2 S.E.

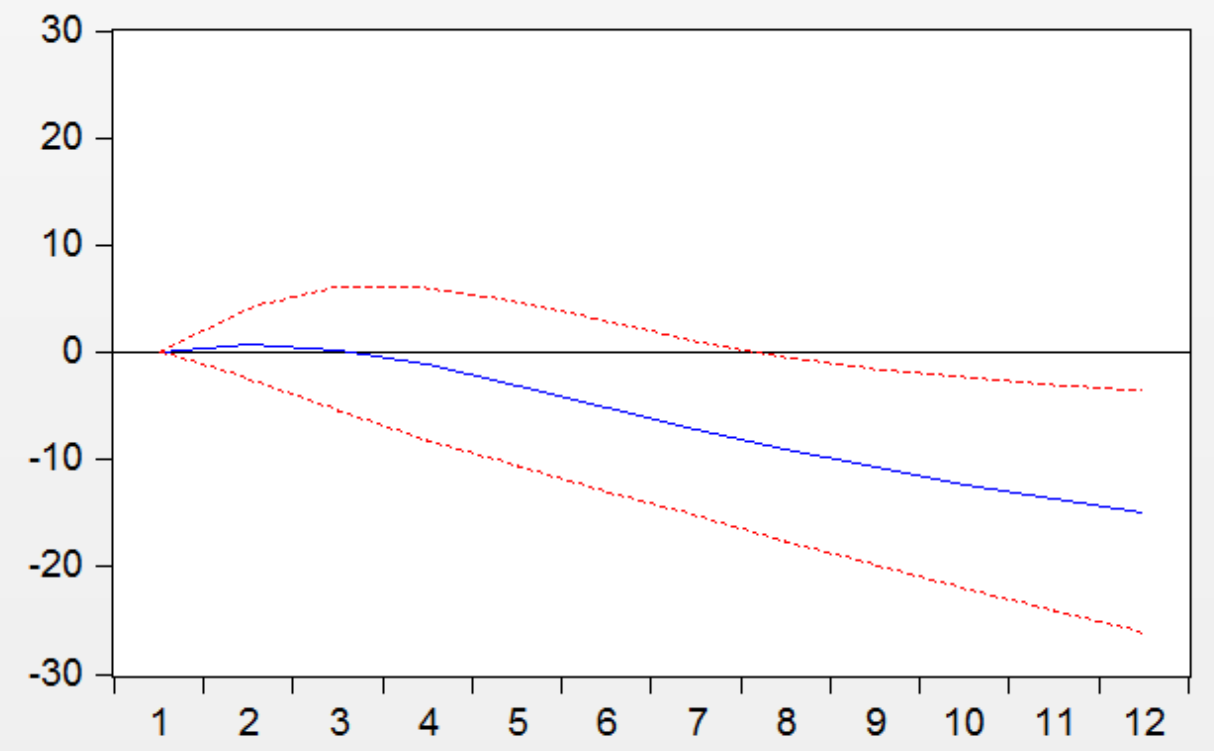

Chart 10: Accumulated response of credit conditions (balance of opinion) to alternative monetary policy shock-Index of Business Confidence replaces output gap in the monetary feedback rule

Accumulated Response to Cholesky One S.D. Innovations \pm 2 S.E.

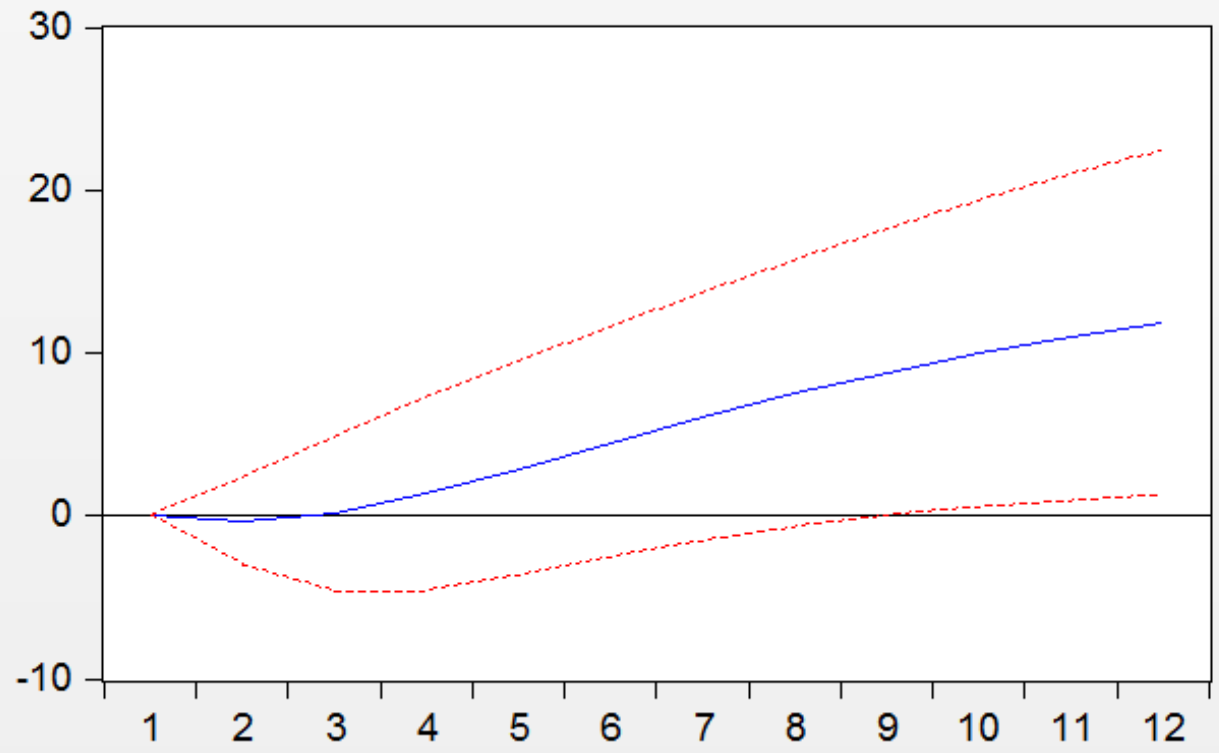

Note: An increase in the balance of opinion in credit conditions means a tightening of credit conditions. 
Chart 11: Accumulated response of output price growth (balance of opinion) to alternative monetary policy shock-Index of Business Confidence replaces output gap in the monetary feedback rule

Accumulated Response to Cholesky One S.D. Innovations \pm 2 S.E.

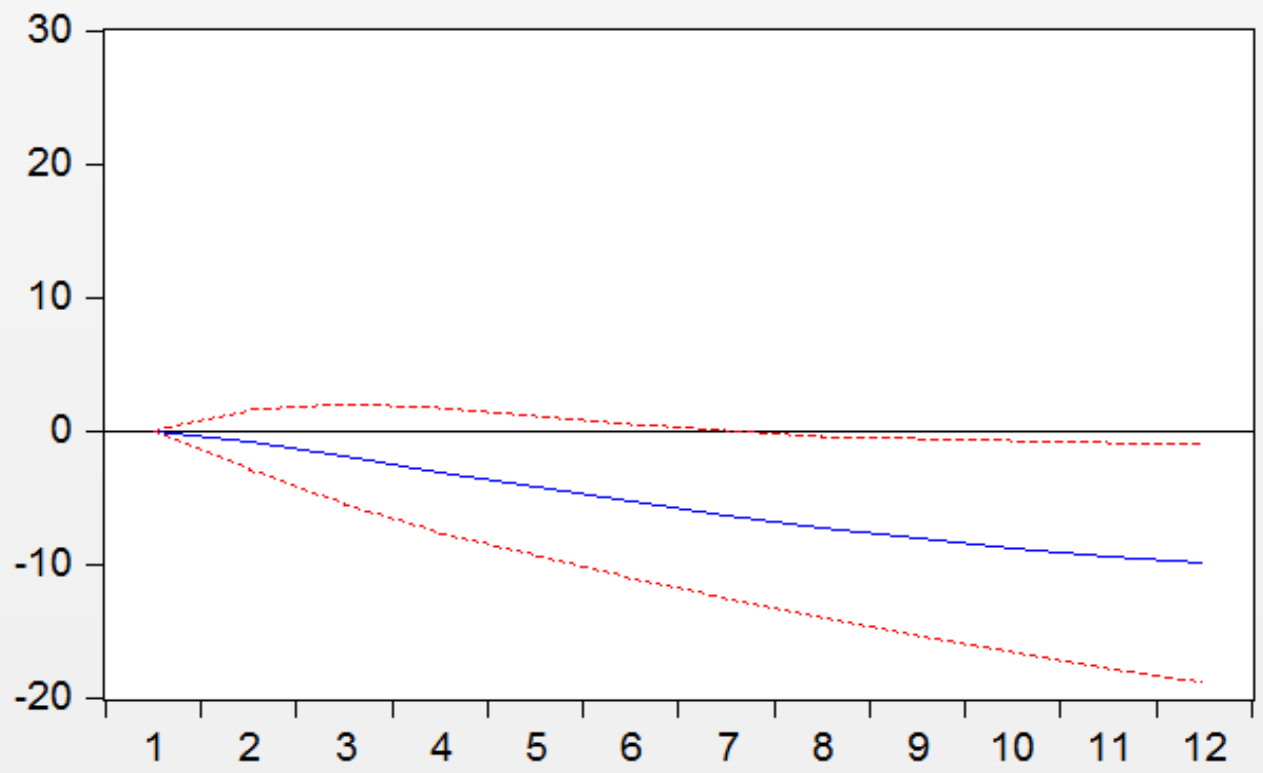

Chart 12: Accumulated response of wage growth (balance of opinion) to alternative monetary policy shock-Index of Business Confidence replaces output gap in the monetary feedback rule

Accumulated Response to Cholesky One S.D. Innovations \pm 2 S.E.

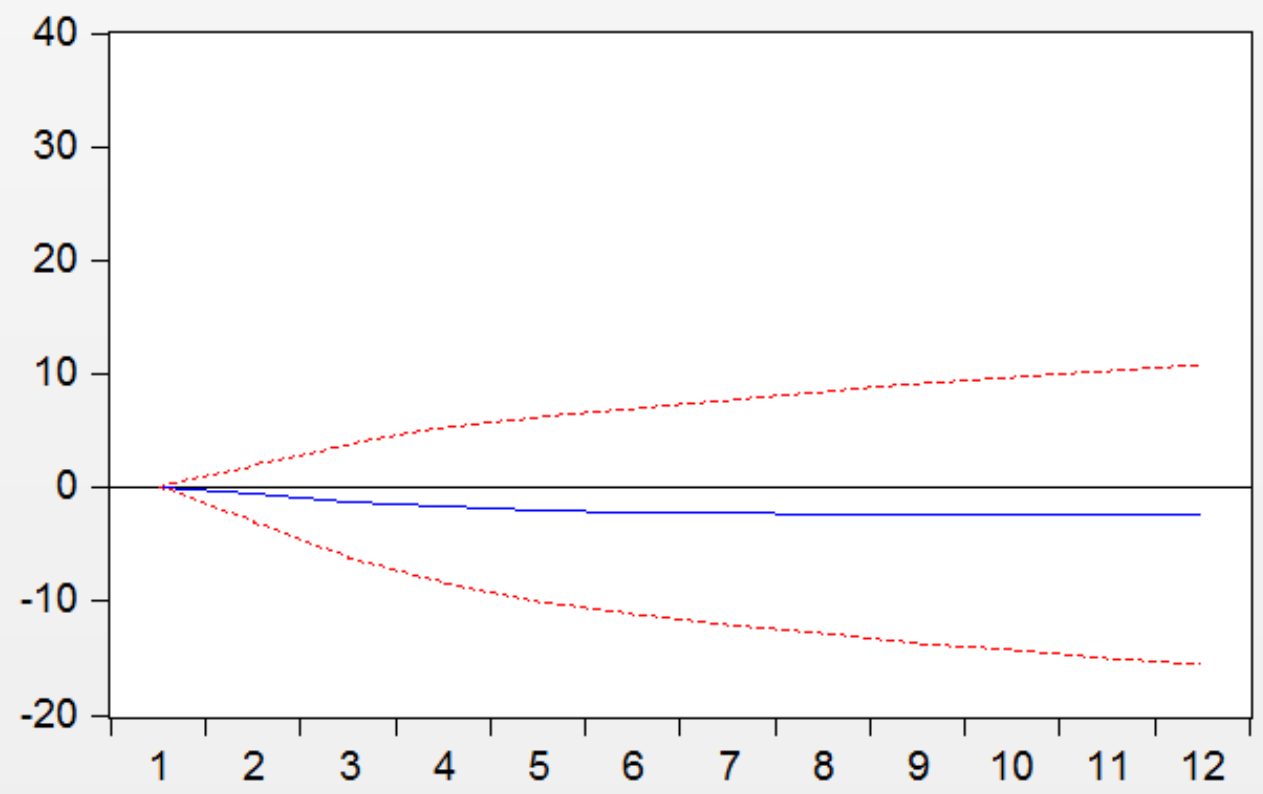


Chart 13: Accumulated response of investment intentions (balance of opinion) to alternative monetary policy shock-Index of Business Confidence replaces output gap in the monetary feedback rule

Accumulated Response to Cholesky One S.D. Innovations \pm 2 S.E.

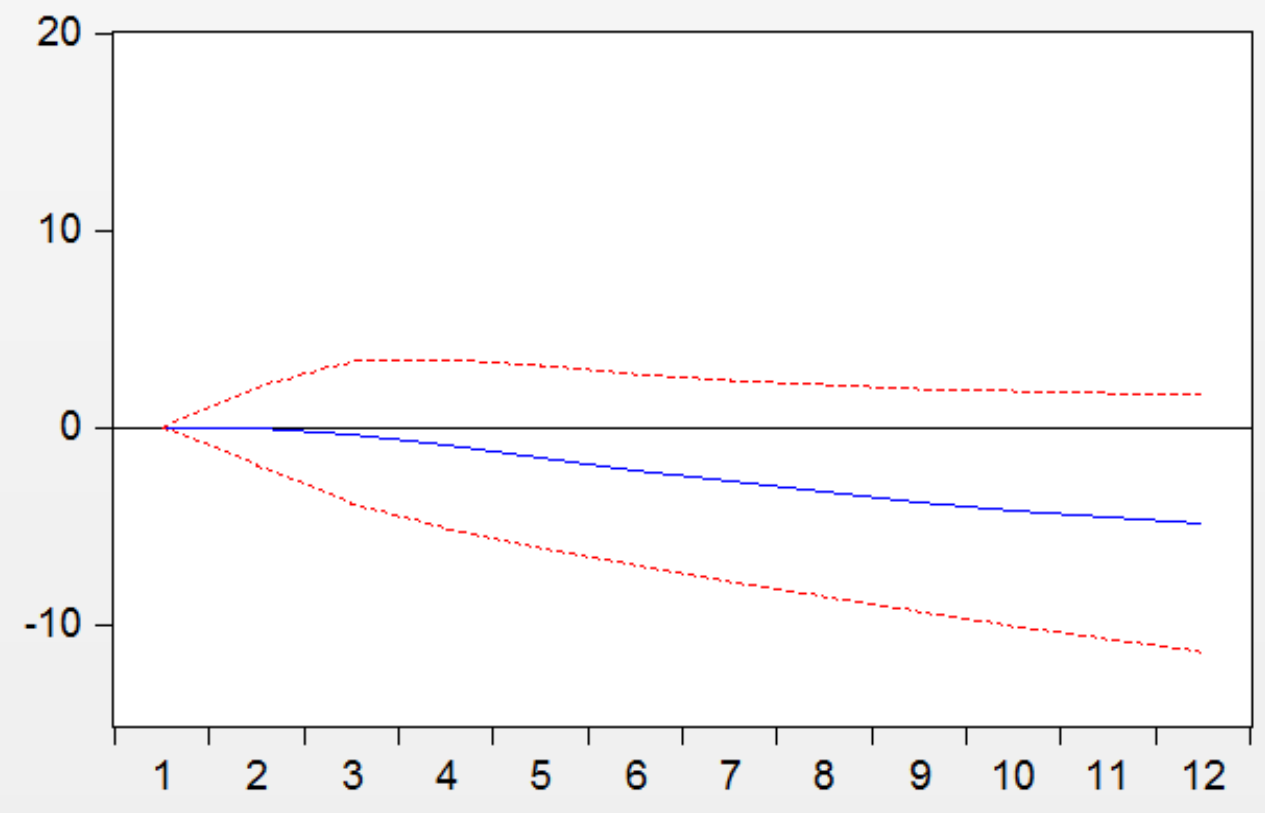




\section{Appendix A: An Overview of the BOS and the BCS}

\section{Business Outlook Survey (Bank of Canada)}

Each quarter, economists from the Bank's five regional offices meet face to face with about 100 company representatives who are at the most senior levels of their organizations. ${ }^{56}$ These firm representatives are knowledgeable about their firms' overall past performance and about their prospects.

The BOS uses a quota-sampling framework. BOS firms are selected such that the overall sample by quarter matches industry sector weights for business GDP (at basic prices) in Canada. ${ }^{57}$ Hence, the selection of firms in the sample is not random. Nevertheless, using simulations, and under certain assumptions, de Munnik et al. $(2013,371)$ find that there is "no evidence that the Bank of Canada's firm selection process results in a wider dispersion in the sampling distribution than the stratified random sample." Thus, despite being a non-probabilistic sample, the BOS seems relatively free of bias and broadly representative of the Canadian business economy. While industrial composition is one of the primary selection criteria for the BOS sample, each of the five regional offices at the Bank is assigned a fixed number of firms to visit in each survey round to reflect some of the regional diversity of the Canadian economy. Finally, efforts are made to have a diverse sample of firms based on their size, with the aim being to have firms of each size (small, medium and large) constitute a third of the sample. ${ }^{58}$

This quota-sampling framework implies that small and medium- (large-) sized firms are over(under-) sampled relative to their share of business sector GDP, as are manufacturers and firms in the Prairies, Atlantic and British Columbia, while firms in Ontario are under-sampled (Table A1). ${ }^{59}$ One should also keep in mind that, since participants are generally not re-interviewed before two years have elapsed, changes in the survey results over time may in part reflect sample rotation (Martin and Papile 2004; Amirault et al. 2017).

56 The Bank's regional offices are located in Halifax (Atlantic Canada), Montréal (Quebec), Toronto (Ontario), Calgary (the Prairies, Northwest Territories and Nunavut) and Vancouver (British Columbia and the Yukon). Survey respondents are typically the chief executive officer, president, chief financial officer, chief operating officer or treasurer.

57 Business sector GDP excludes the public sector. These weights are re-evaluated every two years and are adjusted modestly if and when the industry composition of Canadian business sector GDP has changed materially.

${ }^{58}$ Firm size is defined by the number of employees: small (fewer than 100), medium (100 to 499 ) and large (500 or more). In practice, the "firm size" criterion is of tertiary importance relative to industrial and regional composition.

${ }^{59}$ See also Table 1 in de Munnik et al. (2013). The manufacturing sector is oversampled relative to its share of business sector GDP in recognition of its extensive linkages to other sectors of the economy. 
Table A1: Summary statistics on the firms in the Business Outlook Survey sample-2001Q2 to 2016Q2

\begin{tabular}{|c|c|c|c|c|c|}
\hline Sector & $\%^{\mathrm{a}}$ & Region & $\%^{\mathrm{a}}$ & Size $^{b}$ & $\%^{\mathrm{a}}$ \\
\hline Primary & 8.9 & Atlantic & 15.1 & Small & 30.5 \\
\hline Manufacturing & 25.9 & Quebec & 20.4 & Medium & 33.2 \\
\hline $\begin{array}{l}\text { Construction, information, transportation } \\
\text { services and utilities }\end{array}$ & 19.6 & Ontario & 24.9 & Large & 36.3 \\
\hline Wholesale and retail trade & 14.8 & Prairies & 19.9 & & \\
\hline Finance, insurance and real estate & 13.1 & $\begin{array}{l}\text { British } \\
\text { Columbia }\end{array}$ & 20.4 & & \\
\hline $\begin{array}{l}\text { Commercial, personal and business } \\
\text { services }\end{array}$ & 17.8 & & & & \\
\hline
\end{tabular}

Notes: a. Percentages may not add to 100 because of rounding. b. Small firms employ 1 to 99 persons; medium-sized firms employ 100 to 499; while large firms employ 500 people or more.

The consultations are structured around a survey questionnaire that focuses on business activity (sales), pressures on production capacity, investment, prices, and credit conditions. All the information gathered is qualitative in nature. Below is a description of the BOS variables (see also Martin and Papile 2004) that are used as dependent variables in the analyses of the effects of monetary policy shocks:

1) Business activity (sales): The first question asks whether the change in the growth rate of sales volumes (i.e., adjusted for price changes) over the past 12 months was (i) greater, (ii) lesser or (iii) the same, compared with the preceding 12 months. Firms are also asked whether their sales volumes declined over the past 12 months. Exactly the same question is asked about future sales volumes (i.e., over the next 12 months).

2) Investment: Firms are asked whether the level of investment spending on machinery and equipment over the next 12 months is expected to be (i) higher, (ii) lower or (iii) the same, compared with the past 12 months. The same question is asked for the level of employment (fulltime equivalent).

3) Prices: BOS questions pertaining to the prices a firm pays for labour and charges for its output ask about the expected change, over the next 12 months, in the rate of increase of those prices. The possible answers are (i) greater (e.g., 2 per cent vs. 1 per cent); (ii) lesser; or (iii) the same rate.

4) Credit conditions: Firms are asked how the terms and conditions for obtaining financing changed over the last three months compared to the previous three months, opting between (i) tightened, (ii) eased, (iii) not changed or (iv) not applicable.

Table A2 summarizes the BOS questions used in the BOS indicator and their respective time horizon. 
Table A2: BOS questions used in the BOS indicator

\begin{tabular}{|l|l|}
\hline \multicolumn{1}{|c|}{ Survey question } & \multicolumn{1}{c|}{ Horizon } \\
\hline Balance of opinion a on past sales growth & Past 12 months \\
\hline Balance of opinion on future sales growth & Next 12 months \\
\hline Balance of opinion on investment in machinery and equipment & Next 12 months \\
\hline Balance of opinion on employment & Next 12 months \\
\hline Ability to meet an unexpected increase in demand" & Current \\
\hline Percentage of firms facing labour shortages & Current \\
\hline Balance of opinion on labour-shortage intensity & Current \\
\hline Balance of opinion on input prices & Next 12 months \\
\hline Balance of opinion on output prices & Next 12 months \\
\hline Balance of opinion on credit conditions & Past 3 months \\
\hline $\begin{array}{l}\text { Notes: } \\
\text { a. Percentage of firms responding "greater," "higher" or "more" minus percentage of firms reporting "lesser," "lower" or "less." } \\
\text { b. Percentage of firms responding "some" or "significant" difficulty. }\end{array}$
\end{tabular}

\section{Business confidence survey (Conference Board of Canada)}

The BCS is the Conference Board of Canada's quarterly survey of chief executive officers and chief financial officers of Canadian business organizations. The survey measures perceptions of the current economic environment and the investment intentions of business and has been conducted since 1977. The survey comprises 10 main questions (Conference Board of Canada 2017):

1. Do you expect overall economic conditions in Canada six months from now to be better, same or worse?

2. Do you expect prices, in general, in Canada to increase over the next six months at an annual rate of $1 \%, 2 \%, 3 \%, 4 \%, 5 \%, 6 \%, 7 \%, 8 \%$ or more than $8 \%$ ?

3. Over the next six months, do you expect your firm's financial position to improve, worsen or remain the same?

4. Over the next six months, do you expect your firm's profitability to improve, worsen or remain the same?

5. Would you say the present is a good or a bad time to undertake expenditures to expand your plant or add to your stock of machinery and equipment? (Good, bad, not sure)

6. What change in the level of your capital investment expenditures do you expect over the next 6 months? (Up $20 \%$, up $10 \%$ to $19 \%$, up $1 \%$ to $9 \%$, no change, down $1 \%$ to 9 , down $10 \%$ to $19 \%$, or down $20 \%$ or more)

7. In which region(s) of the country do you expect the bulk of your planned investment expenditures for the next six months to take place? (Atlantic Provinces, Quebec, Ontario, Prairie Provinces, British Columbia, United States, International) 
8. How do you assess your current level of operations relative to optimal capacity? (Above capacity; at or close to capacity; at, close to, or above; slightly below capacity; substantially below capacity)

9. Compared with six months ago, what is your current rate of return to invested capital? (Better than expected, worse than expected, or as expected)

10. What factors, if any, are currently adversely affecting the level of your planned expenditures in Canada? (Appreciation of the Canadian dollar, depreciation of the Canadian dollar, excess productive capacity, foreign competition, government policies, high interest rates, more attractive opportunities outside Canada, overall corporate liquidity, rising cost of capital goods, rising labour costs, shortage of qualified staff, taxes, weak commodity prices, weak market demand)

The Index of Business Confidence (IBC) we use in section 3 is a composite indicator of the difference between changes in the positive and negative responses to three variables included in the survey, rebased to 2002 values. The variables included are (i) the firm's financial position (number of firms responding "improve" minus number responding "worsen"); (ii) planned expenditure on machinery and equipment (number of firms responding "good time to undertake expenditures" minus number of firms responding "bad time"); and (iii) capacity pressures (number of firms responding "at, close to, or above capacity" minus number reporting "substantially below capacity"). 


\section{Bank's Staff Two-Quarters-Ahead Forecasts of Core Inflation Instead of Lagged Total CPI Inflation}

Table B1: Estimated impact of monetary policy shocks on firms' sales perspectives in an ordered logit regression (2001Q2-2016Q1)Monetary policy shocks derived from a forward-looking Taylor rule

\begin{tabular}{|c|c|c|c|c|c|c|c|c|c|c|}
\hline \multirow[b]{2}{*}{ Sum of lags } & \multicolumn{5}{|c|}{ Contemporaneous Monetary Shocks } & \multicolumn{5}{|c|}{ "Exogenous" Monetary Shocks } \\
\hline & Lag 0 & $\begin{array}{l}\text { Lag } 0 \text { to } \\
\text { Lag } 1\end{array}$ & $\begin{array}{l}\text { Lag } 0 \text { to } \\
\operatorname{Lag} 2\end{array}$ & $\begin{array}{l}\text { Lag } 0 \text { to } \\
\operatorname{Lag} 3\end{array}$ & $\begin{array}{l}\text { Lag } 0 \text { to } \\
\text { Lag } 4\end{array}$ & Lag 5 & $\begin{array}{l}\text { Lag } 5 \text { to } \\
\text { Lag } 6\end{array}$ & $\begin{array}{l}\operatorname{Lag} 5 \text { to } \\
\operatorname{Lag} 7\end{array}$ & $\begin{array}{l}\text { Lag } 5 \text { to } \\
\operatorname{Lag} 8\end{array}$ & $\begin{array}{l}\text { Lag } 5 \text { to } \\
\text { Lag } 9\end{array}$ \\
\hline & \multicolumn{10}{|c|}{ Odds Ratios } \\
\hline Standard Taylor rule residuals & $\begin{array}{l}1.210^{* *} \\
(0.115)\end{array}$ & $\begin{array}{c}1.031 \\
(0.0595)\end{array}$ & $\begin{array}{c}0.992 \\
(0.0421)\end{array}$ & $\begin{array}{c}0.958 \\
(0.0335)\end{array}$ & $\begin{array}{l}0.938^{* *} \\
(0.0278)\end{array}$ & $\begin{array}{l}0.687^{* * *} \\
(0.0620)\end{array}$ & $\begin{array}{l}0.745^{* * *} \\
(0.0402)\end{array}$ & $\begin{array}{l}0.761^{* * *} \\
(0.0313)\end{array}$ & $\begin{array}{l}0.794 * * * \\
(0.0280)\end{array}$ & $\begin{array}{l}0.804^{* * *} \\
(0.0253)\end{array}$ \\
\hline $\begin{array}{l}\text { BOS Indicator: } \\
\text { Alternative Taylor rule residuals }\end{array}$ & $\begin{array}{l}1.273^{* *} \\
(0.137)\end{array}$ & $\begin{array}{c}1.100 \\
(0.0756)\end{array}$ & $\begin{array}{c}1.072 \\
(0.0575)\end{array}$ & $\begin{array}{c}1.033 \\
(0.0472)\end{array}$ & $\begin{array}{c}0.980 \\
(0.0394)\end{array}$ & $\begin{array}{l}0.666^{* * *} \\
(0.0740)\end{array}$ & $\begin{array}{l}0.702^{* * *} \\
(0.0472)\end{array}$ & $\begin{array}{l}0.721^{* * *} \\
(0.0372)\end{array}$ & $\begin{array}{l}0.759 * * * \\
(0.0343)\end{array}$ & $\begin{array}{l}0.780^{* * *} \\
(0.0321)\end{array}$ \\
\hline $\begin{array}{l}\text { Index of Business Confidence: } \\
\text { Alternative Taylor rule residuals }\end{array}$ & $\begin{array}{c}1.116 \\
(0.112)\end{array}$ & $\begin{array}{c}0.993 \\
(0.0606)\end{array}$ & $\begin{array}{c}0.984 \\
(0.0473)\end{array}$ & $\begin{array}{c}0.979 \\
(0.0394)\end{array}$ & $\begin{array}{c}0.971 \\
(0.0340)\end{array}$ & $\begin{array}{l}0.764^{* *} \\
(0.0837)\end{array}$ & $\begin{array}{l}0.777^{* * *} \\
(0.0484)\end{array}$ & $\begin{array}{l}0.786 * * * \\
(0.0371)\end{array}$ & $\begin{array}{l}0.808^{* * *} \\
(0.0329)\end{array}$ & $\begin{array}{l}0.801 * * * \\
(0.0298)\end{array}$ \\
\hline Observations & 5,974 & 5,910 & 5,811 & 5,717 & 5,618 & 5,523 & 5,425 & 5,325 & 5,225 & 5,126 \\
\hline Degrees of freedom & 18 & 18 & 18 & 18 & 18 & 18 & 18 & 18 & 18 & 18 \\
\hline Sector dummies & YES & YES & YES & YES & YES & YES & YES & YES & YES & YES \\
\hline Region dummies & YES & YES & YES & YES & YES & YES & YES & YES & YES & YES \\
\hline Quarter dummies & YES & YES & YES & YES & YES & YES & YES & YES & YES & YES \\
\hline Size dummies & YES & YES & YES & YES & YES & YES & YES & YES & YES & YES \\
\hline Macro controls & YES & YES & YES & YES & YES & YES & YES & YES & YES & YES \\
\hline
\end{tabular}

Notes: All Taylor rule estimations are done in real time à la Koenig et al. (2003). Standard Taylor rule residuals denote residuals obtained from estimating equation 2. Alternative Taylor rule residuals denote residuals obtained from estimating equation 2 replacing the output gap by a survey measure of business sentiment (e.g., BOS indicator). Coefficients expressed as odds ratios with robust standard error in parentheses. ${ }^{* * *},{ }^{* * *}$ denote significance at the 10,5 and $1 \%$ level. Macro controls include lagged real US and Canadian GDP growth (Q/Q, SAAR) and WTI oil price (USD) growth (Q/Q). 
Table B2: Estimated impact of monetary policy shocks on firms' future sales indicators in an ordered logit regression (2001Q2-2016Q1)— Monetary policy shocks derived from a forward-looking Taylor rule

$$
\text { Future_Sales_Indicators }_{i t}=\gamma^{\prime} * X_{i t}+\varphi^{\prime} * \text { macro }_{t-1}+\emptyset_{s} * \sum_{i=0}^{i=s} \text { Monetary_Policy_shock }_{t-i}
$$

\begin{tabular}{|c|c|c|c|c|c|c|c|c|c|c|}
\hline \multirow[b]{2}{*}{ Sum of lags } & \multicolumn{5}{|c|}{ Contemporaneous Monetary Shocks } & \multicolumn{5}{|c|}{ "Exogenous" Monetary Shocks } \\
\hline & Lag 0 & $\begin{array}{l}\operatorname{Lag} 0 \text { to } \\
\operatorname{Lag} 1\end{array}$ & $\begin{array}{l}\operatorname{Lag} 0 \text { to } \\
\operatorname{Lag} 2\end{array}$ & $\begin{array}{l}\text { Lag } 0 \text { to } \\
\text { Lag } 3\end{array}$ & $\begin{array}{l}\text { Lag } 0 \text { to } \\
\text { Lag } 4\end{array}$ & Lag 5 & $\begin{array}{l}\operatorname{Lag} 5 \text { to } \\
\operatorname{Lag} 6\end{array}$ & $\begin{array}{l}\text { Lag } 5 \text { to } \\
\text { Lag } 7\end{array}$ & $\begin{array}{l}\operatorname{Lag} 5 \text { to } \\
\operatorname{Lag} 8\end{array}$ & $\begin{array}{l}\operatorname{Lag} 5 \text { to } \\
\operatorname{Lag} 9\end{array}$ \\
\hline & \multicolumn{10}{|c|}{ Odds Ratios } \\
\hline Standard Taylor rule residuals & $\begin{array}{c}1.384^{* * *} \\
(0.153)\end{array}$ & $\begin{array}{l}1.170^{* *} \\
(0.0788)\end{array}$ & $\begin{array}{l}1.181^{* * *} \\
(0.0606)\end{array}$ & $\begin{array}{l}1.164^{* * *} \\
(0.0488)\end{array}$ & $\begin{array}{l}1.127^{* * *} \\
(0.0391)\end{array}$ & $\begin{array}{c}0.908 \\
(0.0951)\end{array}$ & $\begin{array}{l}0.861^{* *} \\
(0.0530)\end{array}$ & $\begin{array}{l}0.887^{* * *} \\
(0.0410)\end{array}$ & $\begin{array}{l}0.891 * * * \\
(0.0339)\end{array}$ & $\begin{array}{r}0.900 * * * \\
(0.0289)\end{array}$ \\
\hline $\begin{array}{l}\text { BOS Indicator: } \\
\text { Alternative Taylor rule residuals }\end{array}$ & $\begin{array}{c}1.188 \\
(0.167)\end{array}$ & $\begin{array}{c}1.094 \\
(0.0907)\end{array}$ & $\begin{array}{l}1.113^{*} \\
(0.0681)\end{array}$ & $\begin{array}{l}1.101^{*} \\
(0.0551)\end{array}$ & $\begin{array}{c}1.057 \\
(0.0463)\end{array}$ & $\begin{array}{c}0.834 \\
(0.107)\end{array}$ & $\begin{array}{l}0.855^{* *} \\
(0.0613)\end{array}$ & $\begin{array}{l}0.869 * * \\
(0.0477)\end{array}$ & $\begin{array}{l}0.857^{* * *} \\
(0.0408)\end{array}$ & $\begin{array}{r}0.858^{* * *} \\
(0.0361)\end{array}$ \\
\hline $\begin{array}{l}\text { Index of Business Confidence: } \\
\text { Alternative Taylor rule residuals }\end{array}$ & $\begin{array}{l}1.299 * * \\
(0.155)\end{array}$ & $\begin{array}{l}1.173^{* *} \\
(0.0850)\end{array}$ & $\begin{array}{l}1.179 * * * \\
(0.0667)\end{array}$ & $\begin{array}{l}1.164^{* * *} \\
(0.0538)\end{array}$ & $\begin{array}{l}1.129 * * * \\
(0.0447)\end{array}$ & $\begin{array}{c}0.978 \\
(0.120)\end{array}$ & $\begin{array}{c}0.908 \\
(0.0625)\end{array}$ & $\begin{array}{c}0.908^{*} \\
(0.0466)\end{array}$ & $\begin{array}{l}0.898^{* *} \\
(0.0385)\end{array}$ & $\begin{array}{r}0.888^{* * *} \\
(0.0336)\end{array}$ \\
\hline Observations & 5,053 & 5,053 & 5,053 & 5,053 & 5,053 & 5,053 & 5,053 & 5,053 & 5,053 & 5,053 \\
\hline Degrees of freedom & 18 & 18 & 18 & 18 & 18 & 18 & 18 & 18 & 18 & 18 \\
\hline Sector dummies & YES & YES & YES & YES & YES & YES & YES & YES & YES & YES \\
\hline Region dummies & YES & YES & YES & YES & YES & YES & YES & YES & YES & YES \\
\hline Quarter dummies & YES & YES & YES & YES & YES & YES & YES & YES & YES & YES \\
\hline Size dummies & YES & YES & YES & YES & YES & YES & YES & YES & YES & YES \\
\hline Macro controls & YES & YES & YES & YES & YES & YES & YES & YES & YES & YES \\
\hline
\end{tabular}

Notes: All Taylor rule estimations are done in real time à la Koenig et al. (2003). Standard Taylor rule residuals denote residuals obtained from estimating equation 2. Alternative Taylor rule residuals denote residuals obtained from estimating equation 2 replacing the output gap by a survey measure of business sentiment (e.g., BOS indicator). Coefficients expressed as odds ratios with robust standard error in parentheses. ${ }^{*}, * *, * *$ denote significance at the 10,5 and $1 \%$ level. Macro controls include lagged real US and Canadian GDP growth (Q/Q, SAAR) and WTI oil price (USD) growth (Q/Q). 
Table B3: Estimated impact of monetary policy shocks on firms' credit conditions in an ordered logit regression (2001Q2-2016Q1)-Monetary policy shocks derived from a forward-looking Taylor rule

$$
\text { Credit_conditions }_{i t}=\gamma^{\prime} * X_{i t}+\varphi^{\prime} * \text { macro }_{t-1}+\emptyset_{s} * \sum_{i=0}^{i=s} \text { Monetary_Policy_shock }_{t-i}
$$

\begin{tabular}{|c|c|c|c|c|c|c|c|c|c|c|}
\hline \multirow[b]{2}{*}{ Sum of lags } & \multicolumn{5}{|c|}{ Contemporaneous Monetary Shocks } & \multicolumn{5}{|c|}{ "Exogenous" Monetary Shocks } \\
\hline & Lag 0 & $\begin{array}{l}\operatorname{Lag} 0 \text { to } \\
\operatorname{Lag} 1\end{array}$ & $\begin{array}{l}\operatorname{Lag} 0 \text { to } \\
\operatorname{Lag} 2\end{array}$ & $\begin{array}{l}\operatorname{Lag} 0 \text { to } \\
\operatorname{Lag} 3\end{array}$ & $\begin{array}{l}\operatorname{Lag} 0 \text { to } \\
\operatorname{Lag} 4\end{array}$ & Lag 5 & $\begin{array}{l}\text { Lag } 5 \text { to } \\
\operatorname{Lag} 6\end{array}$ & $\begin{array}{l}\operatorname{Lag} 5 \text { to } \\
\operatorname{Lag} 7\end{array}$ & $\begin{array}{l}\operatorname{Lag} 5 \text { to } \\
\operatorname{Lag} 8\end{array}$ & $\begin{array}{l}\operatorname{Lag} 5 \text { to } \\
\operatorname{Lag} 9\end{array}$ \\
\hline & \multicolumn{10}{|c|}{ Odds Ratios } \\
\hline Standard Taylor rule residuals & $\begin{array}{l}0.603 * * * \\
(0.0730)\end{array}$ & $\begin{array}{l}0.675 * * * \\
(0.0497)\end{array}$ & $\begin{array}{l}0.719 * * * \\
(0.0388)\end{array}$ & $\begin{array}{l}0.752 * * * \\
(0.0335)\end{array}$ & $\begin{array}{l}0.802^{* * *} \\
(0.0300)\end{array}$ & $\begin{array}{l}1.099 \\
(0.120)\end{array}$ & $\begin{array}{l}1.129 * \\
(0.0728)\end{array}$ & $\begin{array}{l}1.138 * * \\
(0.0577)\end{array}$ & $\begin{array}{l}1.142 * * * \\
(0.0487)\end{array}$ & $\begin{array}{l}1.180 * * * \\
(0.0455)\end{array}$ \\
\hline $\begin{array}{l}\text { BOS Indicator: } \\
\text { Alternative Taylor rule residuals }\end{array}$ & $\begin{array}{l}1.221 \\
(0.168)\end{array}$ & $\begin{array}{c}0.982 \\
(0.0851)\end{array}$ & $\begin{array}{l}0.859 * * \\
(0.0577)\end{array}$ & $\begin{array}{l}0.877^{* *} \\
(0.0501)\end{array}$ & $\begin{array}{c}0.935 \\
(0.0467)\end{array}$ & $\begin{array}{l}1.429 * * \\
(0.202)\end{array}$ & $\begin{array}{c}1.289 * * * \\
(0.106)\end{array}$ & $\begin{array}{l}1.192^{* * *} \\
(0.0753)\end{array}$ & $\begin{array}{l}1.179 * * * \\
(0.0637)\end{array}$ & $\begin{array}{l}1.223^{* * *} \\
(0.0598)\end{array}$ \\
\hline $\begin{array}{l}\text { Index of Business Confidence: } \\
\text { Alternative Taylor rule residuals }\end{array}$ & $\begin{array}{l}0.972 \\
(0.119)\end{array}$ & $\begin{array}{c}0.894 \\
(0.0673)\end{array}$ & $\begin{array}{l}0.814 * * * \\
(0.0484)\end{array}$ & $\begin{array}{l}0.817 * * * \\
(0.0416)\end{array}$ & $\begin{array}{l}0.839 * * * \\
(0.0372)\end{array}$ & $\begin{array}{l}1.004 \\
(0.140)\end{array}$ & $\begin{array}{c}1.112 \\
(0.0873)\end{array}$ & $\begin{array}{c}1.124^{*} \\
(0.0686)\end{array}$ & $\begin{array}{l}1.125^{* *} \\
(0.0582)\end{array}$ & $\begin{array}{c}1.179 * * * \\
(0.0557)\end{array}$ \\
\hline Observations & 4,819 & 4,773 & 4,694 & 4,616 & 4,546 & 4,466 & 4,392 & 4,314 & 4,234 & 4,151 \\
\hline Degrees of freedom & 18 & 18 & 18 & 18 & 18 & 18 & 18 & 18 & 18 & 18 \\
\hline Sector dummies & YES & YES & YES & YES & YES & YES & YES & YES & YES & YES \\
\hline Region dummies & YES & YES & YES & YES & YES & YES & YES & YES & YES & YES \\
\hline Quarter dummies & YES & YES & YES & YES & YES & YES & YES & YES & YES & YES \\
\hline Size dummies & YES & YES & YES & YES & YES & YES & YES & YES & YES & YES \\
\hline Macro controls & YES & YES & YES & YES & YES & YES & YES & YES & YES & YES \\
\hline
\end{tabular}

Notes: All Taylor rule estimations are done in real time à la Koenig et al. (2003). Standard Taylor rule residuals denote residuals obtained from estimating equation 2. Alternative Taylor rule residuals denote residuals obtained from estimating equation 2 replacing the output gap by a survey measure of business sentiment (e.g., BOS indicator). Coefficients expressed as odds ratios with robust standard error in parentheses. *,**,** denote significance at the 10,5 and $1 \%$ level. Macro controls include lagged real US and Canadian GDP growth (Q/Q, SAAR) and WTI oil price (USD) growth (Q/Q). 
Table B4: Estimated impact of monetary policy shocks on firms' output price perspectives in an ordered logit regression (2001Q2-2016Q1)Monetary policy shocks derived from a forward-looking Taylor rule

$$
\text { Output Price growth } h_{i t}=\gamma^{\prime} * X_{i t}+\varphi^{\prime} * \text { macro }_{t-1}+\emptyset_{s} * \sum_{i=0}^{i=s} \text { Monetary_Policy_shock }_{t-i}
$$

\begin{tabular}{|c|c|c|c|c|c|c|c|c|c|c|}
\hline \multirow[b]{2}{*}{ Sum of lags } & \multicolumn{5}{|c|}{ Contemporaneous Monetary Shocks } & \multicolumn{5}{|c|}{ "Exogenous" Monetary Shocks } \\
\hline & Lag 0 & $\begin{array}{l}\operatorname{Lag} 0 \text { to } \\
\operatorname{Lag} 1\end{array}$ & $\begin{array}{l}\text { Lag } 0 \text { to } \\
\text { Lag } 2\end{array}$ & $\begin{array}{l}\text { Lag } 0 \text { to } \\
\text { Lag } 3\end{array}$ & $\begin{array}{l}\text { Lag } 0 \text { to } \\
\text { Lag } 4\end{array}$ & Lag 5 & $\begin{array}{l}\operatorname{Lag} 5 \text { to } \\
\operatorname{Lag} 6\end{array}$ & $\begin{array}{l}\text { Lag } 5 \text { to } \\
\text { Lag } 7\end{array}$ & $\begin{array}{l}\text { Lag } 5 \text { to } \\
\text { Lag } 8\end{array}$ & $\begin{array}{l}\operatorname{Lag} 5 \text { to } \\
\operatorname{Lag} 9\end{array}$ \\
\hline & \multicolumn{10}{|c|}{ Odds Ratios } \\
\hline \multirow{2}{*}{ Standard Taylor rule residuals } & 0.917 & 0.991 & 1.011 & 1.015 & 0.987 & 0.872 & $0.845 * * *$ & $0.849 * * *$ & $0.872^{* * *}$ & $0.864^{* * *}$ \\
\hline & $(0.0876)$ & $(0.0573)$ & $(0.0433)$ & $(0.0363)$ & $(0.0303)$ & $(0.0785)$ & $(0.0447)$ & $(0.0338)$ & $(0.0297)$ & $(0.0263)$ \\
\hline \multirow{2}{*}{$\begin{array}{l}\text { BOS Indicator: } \\
\text { Alternative Taylor rule residuals }\end{array}$} & 0.998 & 1.091 & $1.117^{* *}$ & $1.088^{*}$ & 1.026 & $0.808^{* *}$ & $0.831^{* * *}$ & $0.829 * * *$ & $0.844^{* * *}$ & $0.823 * * *$ \\
\hline & $(0.109)$ & $(0.0740)$ & $(0.0596)$ & $(0.0500)$ & $(0.0412)$ & $(0.0867)$ & $(0.0550)$ & (0.0418) & $(0.0371)$ & $(0.0326)$ \\
\hline \multirow{2}{*}{$\begin{array}{l}\text { Index of Business Confidence: } \\
\text { Alternative Taylor rule residuals }\end{array}$} & 0.934 & 1.017 & 1.026 & 1.015 & 0.982 & $0.781^{* *}$ & $0.818^{* * *}$ & $0.849^{* * *}$ & $0.877^{* * *}$ & $0.867^{* * *}$ \\
\hline & $(0.0957)$ & $(0.0623)$ & $(0.0492)$ & $(0.0413)$ & $(0.0351)$ & (0.0858) & $(0.0507)$ & (0.0398) & $(0.0351)$ & $(0.0316)$ \\
\hline Observations & 5,955 & 5,890 & 5,791 & 5,697 & 5,598 & 5,503 & 5,405 & 5,306 & 5,206 & 5,107 \\
\hline Degrees of freedom & 18 & 18 & 18 & 18 & 18 & 18 & 18 & 18 & 18 & 18 \\
\hline Sector dummies & YES & YES & YES & YES & YES & YES & YES & YES & YES & YES \\
\hline Region dummies & YES & YES & YES & YES & YES & YES & YES & YES & YES & YES \\
\hline Quarter dummies & YES & YES & YES & YES & YES & YES & YES & YES & YES & YES \\
\hline Size dummies & YES & YES & YES & YES & YES & YES & YES & YES & YES & YES \\
\hline Macro controls & YES & YES & YES & YES & YES & YES & YES & YES & YES & YES \\
\hline
\end{tabular}

Notes: All Taylor rule estimations are done in real time à la Koenig et al. (2003). Standard Taylor rule residuals denote residuals obtained from estimating equation 2. Alternative Taylor rule residuals denote residuals obtained from estimating equation 2 replacing the output gap by a survey measure of business sentiment (e.g., BOS indicator). Coefficients expressed as odds ratios with robust standard error in parentheses. *,**,** denote significance at the 10,5 and $1 \%$ level. Macro controls include lagged real US and Canadian GDP growth (Q/Q, SAAR) and WTI oil price (USD) growth (Q/Q). 
Table B5: Estimated impact of monetary policy shocks on firms' wage growth perspectives in an ordered logit regression (2001Q2-2016Q1) Monetary policy shocks derived from a forward-looking Taylor rule

$$
\text { Wage growth }_{i t}=\gamma^{\prime} * X_{i t}+\varphi^{\prime} * \text { macro }_{t-1}+\emptyset_{s} * \sum_{i=0}^{i=s} \text { Monetary_Policy_shock } k_{t-i}
$$

\begin{tabular}{|c|c|c|c|c|c|c|c|c|c|c|}
\hline \multirow[b]{2}{*}{ Sum of lags } & \multicolumn{5}{|c|}{ Contemporaneous Monetary Shocks } & \multicolumn{5}{|c|}{ "Exogenous" Monetary Shocks } \\
\hline & Lag 0 & $\begin{array}{l}\text { Lag } 0 \text { to } \\
\text { Lag } 1\end{array}$ & $\begin{array}{l}\text { Lag } 0 \text { to } \\
\text { Lag } 2\end{array}$ & $\begin{array}{l}\text { Lag } 0 \text { to } \\
\operatorname{Lag} 3\end{array}$ & $\begin{array}{l}\text { Lag } 0 \text { to } \\
\operatorname{Lag} 4\end{array}$ & Lag 5 & $\begin{array}{l}\text { Lag } 5 \text { to } \\
\text { Lag } 6\end{array}$ & $\begin{array}{l}\operatorname{Lag} 5 \text { to } \\
\operatorname{Lag} 7\end{array}$ & $\begin{array}{l}\text { Lag } 5 \text { to } \\
\text { Lag } 8\end{array}$ & $\begin{array}{l}\operatorname{Lag} 5 \text { to } \\
\operatorname{Lag} 9\end{array}$ \\
\hline & \multicolumn{10}{|c|}{ Odds Ratios } \\
\hline Standard Taylor rule residuals & $\begin{array}{l}1.302^{* *} \\
(0.136)\end{array}$ & $\begin{array}{l}1.169 * * \\
(0.0724)\end{array}$ & $\begin{array}{l}1.274 * * * \\
(0.0589)\end{array}$ & $\begin{array}{l}1.280 * * * \\
(0.0490)\end{array}$ & $\begin{array}{l}1.266^{* * *} \\
(0.0416)\end{array}$ & $\begin{array}{c}0.998 \\
(0.0969)\end{array}$ & $\begin{array}{c}1.001 \\
(0.0568)\end{array}$ & $\begin{array}{c}1.012 \\
(0.0445)\end{array}$ & $\begin{array}{c}1.047 \\
(0.0396)\end{array}$ & $\begin{array}{c}0.992 \\
(0.0333)\end{array}$ \\
\hline $\begin{array}{l}\text { BOS Indicator: } \\
\text { Alternative Taylor rule residuals }\end{array}$ & $\begin{array}{l}1.153 \\
(0.136)\end{array}$ & $\begin{array}{c}1.103 \\
(0.0806)\end{array}$ & $\begin{array}{l}1.269 * * * \\
(0.0728)\end{array}$ & $\begin{array}{l}1.267^{* * *} \\
(0.0625)\end{array}$ & $\begin{array}{l}1.208 * * * \\
(0.0523)\end{array}$ & $\begin{array}{l}0.701^{* * *} \\
(0.0823)\end{array}$ & $\begin{array}{c}0.871^{*} \\
(0.0620)\end{array}$ & $\begin{array}{l}0.892^{* *} \\
(0.0493)\end{array}$ & $\begin{array}{c}0.968 \\
(0.0467)\end{array}$ & $\begin{array}{l}0.912 * * \\
(0.0386)\end{array}$ \\
\hline $\begin{array}{l}\text { Index of Business Confidence: } \\
\text { Alternative Taylor rule residuals }\end{array}$ & $\begin{array}{l}1.196 * \\
(0.129)\end{array}$ & $\begin{array}{l}1.168^{* *} \\
(0.0753)\end{array}$ & $\begin{array}{l}1.284 * * * \\
(0.0647)\end{array}$ & $\begin{array}{l}1.330 * * * \\
(0.0570)\end{array}$ & $\begin{array}{l}1.303 * * * \\
(0.0493)\end{array}$ & $\begin{array}{c}0.901 \\
(0.104)\end{array}$ & $\begin{array}{c}0.892^{*} \\
(0.0584)\end{array}$ & $\begin{array}{c}0.932 \\
(0.0477)\end{array}$ & $\begin{array}{c}0.973 \\
(0.0431)\end{array}$ & $\begin{array}{c}0.925^{*} \\
(0.0372)\end{array}$ \\
\hline Observations & 5,967 & 5,902 & 5,803 & 5,709 & 5,610 & 5,515 & 5,417 & 5,317 & 5,217 & 5,118 \\
\hline Degrees of freedom & 18 & 18 & 18 & 18 & 18 & 18 & 18 & 18 & 18 & 18 \\
\hline Sector dummies & YES & YES & YES & YES & YES & YES & YES & YES & YES & YES \\
\hline Region dummies & YES & YES & YES & YES & YES & YES & YES & YES & YES & YES \\
\hline Quarter dummies & YES & YES & YES & YES & YES & YES & YES & YES & YES & YES \\
\hline Size dummies & YES & YES & YES & YES & YES & YES & YES & YES & YES & YES \\
\hline Macro controls & YES & YES & YES & YES & YES & YES & YES & YES & YES & YES \\
\hline
\end{tabular}

Notes: All Taylor rule estimations are done in real time à la Koenig et al. (2003). Standard Taylor rule residuals denote residuals obtained from estimating equation 2. Alternative Taylor rule residuals denote residuals obtained from estimating equation 2 replacing the output gap by a survey measure of business sentiment (e.g., BOS indicator). Coefficients expressed as odds ratios with robust standard error in parentheses. ${ }^{* * *}, * * *$ denote significance at the 10,5 and $1 \%$ level. Macro controls include lagged real US and Canadian GDP growth (Q/Q, SAAR) and WTI oil price (USD) growth (Q/Q). 
Table B6: Estimated impact of monetary policy shocks on firms' investment intentions in an ordered logit regression (2001Q2-2016Q1)Monetary policy shocks derived from a forward-looking Taylor rule

$$
\text { Investment }_{i t}=\gamma^{\prime} * X_{i t}+\varphi^{\prime} * \text { macro }_{t-1}+\emptyset_{s} * \sum_{i=0}^{i=s} \text { Monetary_Policy_shock }_{t-i}
$$

\begin{tabular}{|c|c|c|c|c|c|c|c|c|c|c|c|}
\hline \multirow[b]{2}{*}{ Sum of lags } & \multicolumn{5}{|c|}{ Contemporaneous Monetary Shocks } & \multicolumn{6}{|c|}{ "Exogenous" Monetary Shocks } \\
\hline & Lag 0 & $\begin{array}{l}\text { Lag } 0 \text { to } \\
\text { Lag } 1\end{array}$ & $\begin{array}{l}\text { Lag } 0 \text { to } \\
\text { Lag } 2\end{array}$ & $\begin{array}{l}\text { Lag } 0 \text { to } \\
\operatorname{Lag} 3\end{array}$ & $\begin{array}{l}\text { Lag } 0 \text { to } \\
\text { Lag } 4\end{array}$ & Lag 5 & $\begin{array}{l}\text { Lag } 5 \text { to } \\
\text { Lag } 6\end{array}$ & $\ldots$ & $\begin{array}{ll}\text { Lag } 5 & \text { to } \\
\text { Lag } 10 & \end{array}$ & $\begin{array}{ll}\text { Lag } 5 & \text { to } \\
\operatorname{Lag} 11 & \end{array}$ & $\begin{array}{ll}\text { Lag } 5 & \text { to } \\
\operatorname{Lag} 12 & \end{array}$ \\
\hline & \multicolumn{11}{|c|}{ Odds Ratios } \\
\hline \multirow{2}{*}{ Standard Taylor rule residuals } & $1.210^{* *}$ & $1.124^{* *}$ & $1.120 * * *$ & $1.088^{* *}$ & $1.072^{* *}$ & $1.241^{* *}$ & 1.085 & $\ldots$ & 0.979 & 0.963 & $0.948^{* *}$ \\
\hline & $(0.115)$ & $(0.0643)$ & $(0.0482)$ & $(0.0389)$ & $(0.0331)$ & $(0.112)$ & (0.0569) & & $(0.0270)$ & $(0.0247)$ & $(0.0229)$ \\
\hline BOS Indicator: & 0.996 & 1.003 & 1.058 & 1.044 & 1.012 & 0.970 & 0.998 & $\ldots$ & $0.928^{* *}$ & $0.923 * *$ & $0.916^{* *}$ \\
\hline Alternative Taylor rule residuals & $(0.108)$ & $(0.0680)$ & $(0.0568)$ & $(0.0481)$ & $(0.0411)$ & $(0.108)$ & $(0.0666)$ & & $(0.0353)$ & $(0.0333)$ & $(0.0318)$ \\
\hline Index of Business Confidence: & 1.065 & 1.054 & 1.076 & 1.055 & 1.046 & $1.230 *$ & 1.064 & $\ldots$ & 0.955 & $0.934 * *$ & $0.907 * *$ \\
\hline Alternative Taylor rule residuals & (0.108) & $(0.0645)$ & $(0.0525)$ & $(0.0434)$ & $(0.0377)$ & (0.138) & $(0.0674)$ & & $(0.0324)$ & $(0.0300)$ & $(0.0285)$ \\
\hline Observations & 5,918 & 5,855 & 5,757 & 5,664 & 5,566 & 5,475 & 5,382 & & 4,998 & 4,899 & 4,799 \\
\hline Degrees of freedom & 18 & 18 & 18 & 18 & 18 & 18 & 18 & & 18 & 18 & 18 \\
\hline Sector dummies & YES & YES & YES & YES & YES & YES & YES & & YES & YES & YES \\
\hline Region dummies & YES & YES & YES & YES & YES & YES & YES & & YES & YES & YES \\
\hline Quarter dummies & YES & YES & YES & YES & YES & YES & YES & & YES & YES & YES \\
\hline Size dummies & YES & YES & YES & YES & YES & YES & YES & & YES & YES & YES \\
\hline Macro controls & YES & YES & YES & YES & YES & YES & YES & & YES & YES & YES \\
\hline
\end{tabular}

Notes: All Taylor rule estimations are done in real time à la Koenig et al. (2003). Standard Taylor rule residuals denote residuals obtained from estimating equation 2. Alternative Taylor rule residuals denote residuals obtained from estimating equation 2 replacing the output gap by a survey measure of business sentiment (e.g., BOS indicator). Coefficients expressed as odds ratios with robust standard error in parentheses. ${ }^{* * *}, * * *$ denote significance at the 10,5 and $1 \%$ level. Macro controls include lagged real US and Canadian GDP growth (Q/Q, SAAR) and WTI oil price (USD) growth (Q/Q). 


\section{Appendix C: Impact of Monetary Policy Shocks on the Sub-sample of BOS firms that are Potentially}

\section{Affected by the Interest Rate Channel (i.e., that are not fully self-financed)—Credit Conditions Sample}

Table C1: Estimated impact of monetary policy shocks on firms' sales perspectives in an ordered logit regression (2001Q2-2016Q1)-Credit conditions sample

$$
\text { Future_Sales }_{i t}=\gamma^{\prime} * X_{i t}+\varphi^{\prime} * \text { macro }_{t-1}+\emptyset_{s} * \sum_{i=0}^{i=s} \text { Monetary_Policy_shock } k_{t-i}
$$

\begin{tabular}{|c|c|c|c|c|c|c|c|c|c|c|}
\hline \multirow[b]{2}{*}{ Sum of lags } & \multicolumn{5}{|c|}{ Contemporaneous Monetary Shocks } & \multicolumn{5}{|c|}{ "Exogenous" Monetary Shocks } \\
\hline & Lag 0 & $\begin{array}{l}\text { Lag } 0 \text { to } \\
\text { Lag } 1\end{array}$ & $\begin{array}{l}\text { Lag } 0 \text { to } \\
\text { Lag } 2\end{array}$ & $\begin{array}{l}\text { Lag } 0 \text { to } \\
\text { Lag } 3\end{array}$ & $\begin{array}{l}\text { Lag } 0 \text { to } \\
\text { Lag } 4\end{array}$ & Lag 5 & $\begin{array}{l}\text { Lag } 5 \text { to } \\
\text { Lag } 6\end{array}$ & $\begin{array}{l}\text { Lag } 5 \text { to } \\
\operatorname{Lag} 7\end{array}$ & $\begin{array}{l}\text { Lag } 5 \text { to } \\
\text { Lag } 8\end{array}$ & $\begin{array}{l}\text { Lag } 5 \text { to } \\
\text { Lag } 9\end{array}$ \\
\hline & \multicolumn{10}{|c|}{ Odds Ratios } \\
\hline Standard Taylor rule residuals & $\begin{array}{c}1.315^{* * *} \\
(0.132)\end{array}$ & $\begin{array}{c}1.087 \\
(0.0655)\end{array}$ & $\begin{array}{c}0.987 \\
(0.0425)\end{array}$ & $\begin{array}{l}0.944^{*} \\
(0.0327)\end{array}$ & $\begin{array}{l}0.919 * * * \\
(0.0271)\end{array}$ & $\begin{array}{l}0.597^{* * *} \\
(0.0567)\end{array}$ & $\begin{array}{l}0.737^{* * *} \\
(0.0401)\end{array}$ & $\begin{array}{l}0.773^{* * *} \\
(0.0320)\end{array}$ & $\begin{array}{l}0.799 * * * \\
(0.0291)\end{array}$ & $\begin{array}{l}0.814^{* * *} \\
(0.0271)\end{array}$ \\
\hline $\begin{array}{l}\text { BOS Indicator: } \\
\text { Alternative Taylor rule residuals }\end{array}$ & $\begin{array}{c}1.367^{* * *} \\
(0.156)\end{array}$ & $\begin{array}{c}1.098 \\
(0.0778)\end{array}$ & $\begin{array}{c}1.031 \\
(0.0554)\end{array}$ & $\begin{array}{c}0.988 \\
(0.0446)\end{array}$ & $\begin{array}{c}0.945 \\
(0.0375)\end{array}$ & $\begin{array}{l}0.621^{* * *} \\
(0.0729)\end{array}$ & $\begin{array}{l}0.724^{* * *} \\
(0.0494)\end{array}$ & $\begin{array}{l}0.755^{* * *} \\
(0.0390)\end{array}$ & $\begin{array}{l}0.797^{* * *} \\
(0.0360)\end{array}$ & $\begin{array}{r}0.828^{* * *} \\
(0.0344)\end{array}$ \\
\hline $\begin{array}{l}\text { Index of Business Confidence: } \\
\text { Alternative Taylor rule residuals }\end{array}$ & $\begin{array}{c}1.183 \\
(0.126)\end{array}$ & $\begin{array}{c}1.003 \\
(0.0636)\end{array}$ & $\begin{array}{c}0.957 \\
(0.0466)\end{array}$ & $\begin{array}{c}0.945 \\
(0.0380)\end{array}$ & $\begin{array}{l}0.934^{*} \\
(0.0328)\end{array}$ & $\begin{array}{l}0.719 * * * \\
(0.0823)\end{array}$ & $\begin{array}{l}0.786 * * * \\
(0.0497)\end{array}$ & $\begin{array}{l}0.813^{* * *} \\
(0.0386)\end{array}$ & $\begin{array}{l}0.833^{* * *} \\
(0.0344)\end{array}$ & $\begin{array}{l}0.830^{* * *} \\
(0.0318)\end{array}$ \\
\hline Observations & 4,814 & 4,768 & 4,689 & 4,611 & 4,541 & 4,461 & 4,387 & 4,309 & 4,229 & 4,146 \\
\hline Degrees of freedom & 18 & 18 & 18 & 18 & 18 & 18 & 18 & 18 & 18 & 18 \\
\hline Sector dummies & YES & YES & YES & YES & YES & YES & YES & YES & YES & YES \\
\hline Region dummies & YES & YES & YES & YES & YES & YES & YES & YES & YES & YES \\
\hline Quarter dummies & YES & YES & YES & YES & YES & YES & YES & YES & YES & YES \\
\hline Size dummies & YES & YES & YES & YES & YES & YES & YES & YES & YES & YES \\
\hline Macro controls & YES & YES & YES & YES & YES & YES & YES & YES & YES & YES \\
\hline
\end{tabular}

Notes: All Taylor rule estimations are done in real time à la Koenig et al. (2003). Standard Taylor rule residuals denote residuals obtained from estimating equation 1. Alternative Taylor rule residuals denote residuals obtained from estimating equation 1.1 excluding the output gap. Coefficients expressed as odds ratios with robust standard error in parentheses. *,**,** denote significance at the 10, 5 and $1 \%$ level. Macro controls include lagged real US and Canadian GDP growth (Q/Q, SAAR) and WTI oil price (USD) growth (Q/Q). 
Table C2: Estimated impact of monetary policy shocks on firms' future sales indicators in an ordered logit regression (2001Q2-2016Q1)Credit conditions sample

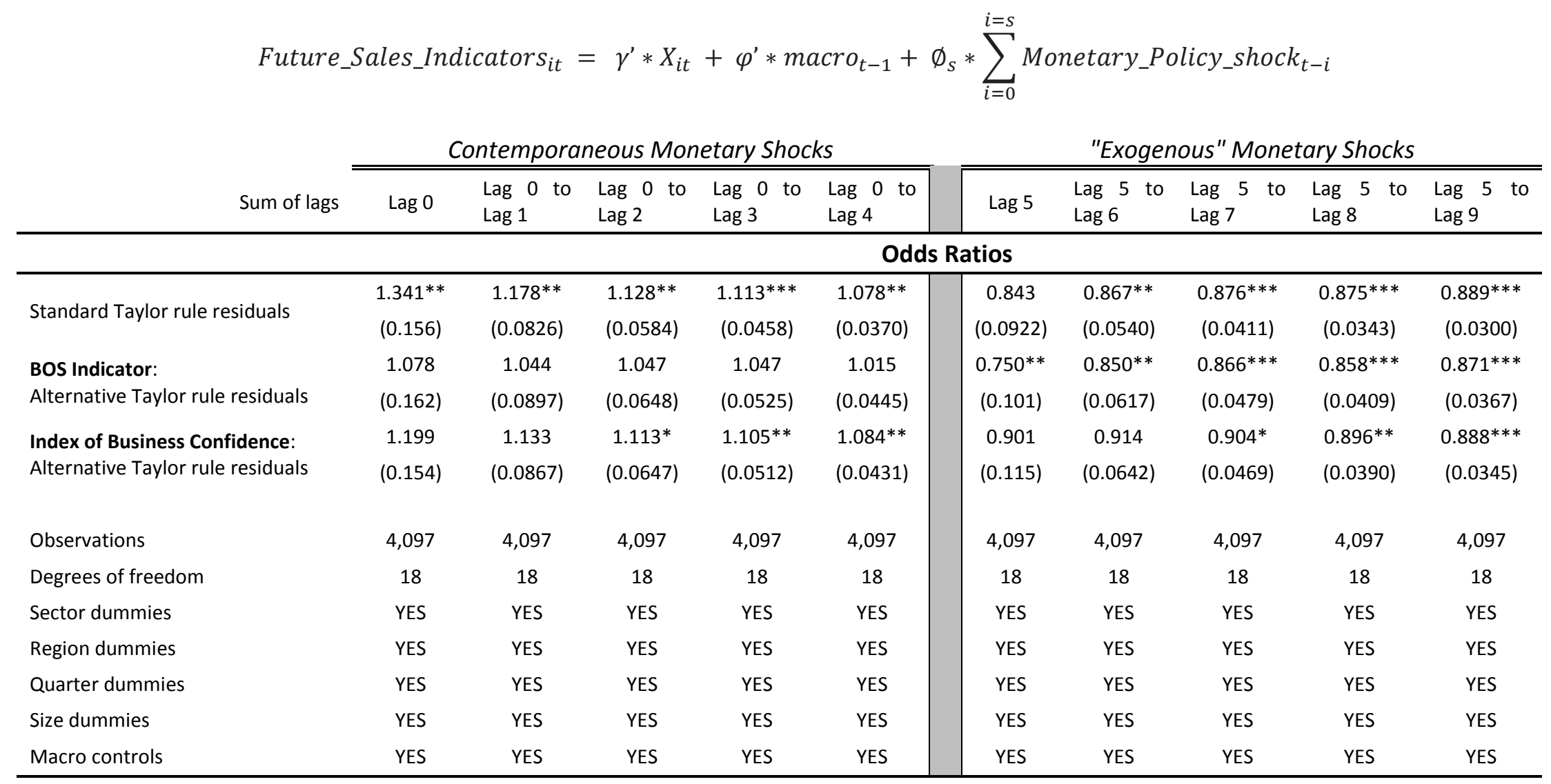

Notes: All Taylor rule estimations are done in real time à la Koenig et al. (2003). Standard Taylor rule residuals denote residuals obtained from estimating equation 1. Alternative Taylor rule residuals denote residuals obtained from estimating equation 1.1 excluding the output gap. Coefficients expressed as odds ratios with robust standard error in parentheses. *,**,*** denote significance at the 10, 5 and $1 \%$ level. Macro controls include lagged real US and Canadian GDP growth (Q/Q, SAAR) and WTI oil price (USD) growth (Q/Q). 
Table C3: Estimated impact of monetary policy shocks on firms' output price perspectives in an ordered logit regression (2001Q2-2016Q1)— Credit conditions sample

$$
\text { Output Price growth } h_{i t}=\gamma^{\prime} * X_{i t}+\varphi^{\prime} * \text { macro }_{t-1}+\emptyset_{s} * \sum_{i=0}^{i=s} \text { Monetary_Policy_shock }_{t-i}
$$

\begin{tabular}{|c|c|c|c|c|c|c|c|c|c|c|}
\hline \multirow[b]{2}{*}{ Sum of lags } & \multicolumn{5}{|c|}{ Contemporaneous Monetary Shocks } & \multicolumn{5}{|c|}{ "Exogenous" Monetary Shocks } \\
\hline & $\operatorname{Lag} 0$ & $\begin{array}{l}\text { Lag } 0 \text { to } \\
\text { Lag } 1\end{array}$ & $\begin{array}{l}\text { Lag } 0 \text { to } \\
\text { Lag } 2\end{array}$ & $\begin{array}{l}\text { Lag } 0 \text { to } \\
\text { Lag } 3\end{array}$ & $\begin{array}{l}\operatorname{Lag} 0 \text { to } \\
\operatorname{Lag} 4\end{array}$ & Lag 5 & $\begin{array}{l}\text { Lag } 5 \text { to } \\
\text { Lag } 6\end{array}$ & $\begin{array}{l}\text { Lag } 5 \text { to } \\
\operatorname{Lag} 7\end{array}$ & $\begin{array}{l}\text { Lag } 5 \text { to } \\
\operatorname{Lag} 8\end{array}$ & $\begin{array}{l}\operatorname{Lag} 5 \text { to } \\
\operatorname{Lag} 9\end{array}$ \\
\hline & \multicolumn{10}{|c|}{ Odds Ratios } \\
\hline \multirow{2}{*}{ Standard Taylor rule residuals } & 1.117 & 1.074 & 1.049 & 1.028 & 0.993 & $0.833^{*}$ & $0.850^{* * *}$ & $0.843^{* * *}$ & $0.849^{* * *}$ & $0.846 * * *$ \\
\hline & $(0.113)$ & $(0.0655)$ & $(0.0463)$ & $(0.0369)$ & $(0.0305)$ & $(0.0784)$ & $(0.0455)$ & $(0.0343)$ & $(0.0302)$ & $(0.0277)$ \\
\hline \multirow{2}{*}{$\begin{array}{l}\text { BOS Indicator: } \\
\text { Alternative Taylor rule residuals }\end{array}$} & $1.213^{*}$ & $1.169 * *$ & $1.142^{* *}$ & $1.087^{*}$ & 1.030 & $0.760^{* *}$ & $0.817^{* * *}$ & $0.815^{* * *}$ & $0.821^{* * *}$ & $0.821^{* * *}$ \\
\hline & $(0.141)$ & $(0.0828)$ & $(0.0616)$ & $(0.0494)$ & $(0.0407)$ & $(0.0861)$ & $(0.0551)$ & $(0.0415)$ & $(0.0366)$ & $(0.0332)$ \\
\hline \multirow{2}{*}{$\begin{array}{l}\text { Index of Business Confidence: } \\
\text { Alternative Taylor rule residuals }\end{array}$} & 1.069 & 1.082 & 1.063 & 1.034 & 0.996 & $0.732^{* * *}$ & $0.810^{* * *}$ & $0.833^{* * *}$ & $0.853^{* * *}$ & $0.856^{* * *}$ \\
\hline & $(0.116)$ & $(0.0692)$ & $(0.0522)$ & $(0.0421)$ & $(0.0357)$ & $(0.0847)$ & $(0.0514)$ & $(0.0398)$ & $(0.0351)$ & $(0.0325)$ \\
\hline Observations & 4,801 & 4,755 & 4,676 & 4,598 & 4,528 & 4,448 & 4,374 & 4,297 & 4,217 & 4,134 \\
\hline Degrees of freedom & 18 & 18 & 18 & 18 & 18 & 18 & 18 & 18 & 18 & 18 \\
\hline Sector dummies & YES & YES & YES & YES & YES & YES & YES & YES & YES & YES \\
\hline Region dummies & YES & YES & YES & YES & YES & YES & YES & YES & YES & YES \\
\hline Quarter dummies & YES & YES & YES & YES & YES & YES & YES & YES & YES & YES \\
\hline Size dummies & YES & YES & YES & YES & YES & YES & YES & YES & YES & YES \\
\hline Macro controls & YES & YES & YES & YES & YES & YES & YES & YES & YES & YES \\
\hline
\end{tabular}

Notes: Standard Taylor rule residuals denote residuals obtained from estimating equation 1 . Alternative Taylor rule residuals denote residuals obtained from estimating equation 1.1 excluding the output gap. Coefficients expressed as odds ratios with robust standard error in parentheses. $* * *, * * *$ denote significance at the 10,5 and $1 \%$ level. Macro controls include lagged real US and Canadian GDP growth (Q/Q, SAAR) and WTI oil price (USD) growth (Q/Q). 
Table C4: Estimated impact of monetary policy shocks on firms' wage growth perspectives in an ordered logit regression (2001Q2-2016Q1)— Credit conditions sample

$$
\text { Wage growth }_{i t}=\gamma^{\prime} * X_{i t}+\varphi^{\prime} * \text { macro }_{t-1}+\emptyset_{s} * \sum_{i=0}^{i=s} \text { Monetary_Policy_shock } k_{t-i}
$$

\begin{tabular}{|c|c|c|c|c|c|c|c|c|c|c|}
\hline \multirow[b]{2}{*}{ Sum of lags } & \multicolumn{5}{|c|}{ Contemporaneous Monetary Shocks } & \multicolumn{5}{|c|}{ "Exogenous" Monetary Shocks } \\
\hline & Lag 0 & $\begin{array}{l}\text { Lag } 0 \text { to } \\
\text { Lag } 1\end{array}$ & $\begin{array}{l}\text { Lag } 0 \text { to } \\
\text { Lag } 2\end{array}$ & $\begin{array}{l}\text { Lag } 0 \text { to } \\
\text { Lag } 3\end{array}$ & $\begin{array}{l}\text { Lag } 0 \text { to } \\
\text { Lag } 4\end{array}$ & Lag 5 & $\begin{array}{l}\operatorname{Lag} 5 \text { to } \\
\operatorname{Lag} 6\end{array}$ & $\begin{array}{l}\operatorname{Lag} 5 \text { to } \\
\operatorname{Lag} 7\end{array}$ & $\begin{array}{l}\text { Lag } 5 \text { to } \\
\text { Lag } 8\end{array}$ & $\begin{array}{l}\operatorname{Lag} 5 \text { to } \\
\operatorname{Lag} 9\end{array}$ \\
\hline & \multicolumn{10}{|c|}{ Odds Ratios } \\
\hline Standard Taylor rule residuals & $\begin{array}{c}1.630^{* * *} \\
(0.181)\end{array}$ & $\begin{array}{l}1.317^{* * *} \\
(0.0856)\end{array}$ & $\begin{array}{l}1.317^{* * *} \\
(0.0628)\end{array}$ & $\begin{array}{l}1.265^{* * *} \\
(0.0488)\end{array}$ & $\begin{array}{l}1.227^{* * *} \\
(0.0406)\end{array}$ & $\begin{array}{c}0.929 \\
(0.0982)\end{array}$ & $\begin{array}{c}0.947 \\
(0.0554)\end{array}$ & $\begin{array}{c}0.963 \\
(0.0435)\end{array}$ & $\begin{array}{c}0.985 \\
(0.0389)\end{array}$ & $\begin{array}{l}0.936^{*} \\
(0.0336)\end{array}$ \\
\hline $\begin{array}{l}\text { BOS Indicator: } \\
\text { Alternative Taylor rule residuals }\end{array}$ & $\begin{array}{c}1.215 \\
(0.154)\end{array}$ & $\begin{array}{c}1.121 \\
(0.0852)\end{array}$ & $\begin{array}{l}1.227^{* * *} \\
(0.0708)\end{array}$ & $\begin{array}{l}1.198^{* * *} \\
(0.0584)\end{array}$ & $\begin{array}{l}1.148^{* * *} \\
(0.0491)\end{array}$ & $\begin{array}{l}0.658^{* * *} \\
(0.0822)\end{array}$ & $\begin{array}{l}0.839^{* *} \\
(0.0615)\end{array}$ & $\begin{array}{l}0.856^{* * *} \\
(0.0476)\end{array}$ & $\begin{array}{l}0.912^{*} \\
(0.0439)\end{array}$ & $\begin{array}{r}0.871^{* * *} \\
(0.0374)\end{array}$ \\
\hline $\begin{array}{l}\text { Index of Business Confidence: } \\
\text { Alternative Taylor rule residuals }\end{array}$ & $\begin{array}{c}1.371^{* * *} \\
(0.156)\end{array}$ & $\begin{array}{l}1.267^{* * *} \\
(0.0843)\end{array}$ & $\begin{array}{l}1.295^{* * *} \\
(0.0662)\end{array}$ & $\begin{array}{l}1.301^{* * *} \\
(0.0556)\end{array}$ & $\begin{array}{l}1.263^{* * *} \\
(0.0478)\end{array}$ & $\begin{array}{c}0.832 \\
(0.102)\end{array}$ & $\begin{array}{l}0.844^{* *} \\
(0.0569)\end{array}$ & $\begin{array}{l}0.881^{* *} \\
(0.0457)\end{array}$ & $\begin{array}{l}0.908^{* *} \\
(0.0410)\end{array}$ & $\begin{array}{l}0.866^{* * *} \\
(0.0358)\end{array}$ \\
\hline Observations & 4,806 & 4,760 & 4,681 & 4,603 & 4,533 & 4,453 & 4,379 & 4,301 & 4,221 & 4,138 \\
\hline Degrees of freedom & 18 & 18 & 18 & 18 & 18 & 18 & 18 & 18 & 18 & 18 \\
\hline Sector dummies & YES & YES & YES & YES & YES & YES & YES & YES & YES & YES \\
\hline Region dummies & YES & YES & YES & YES & YES & YES & YES & YES & YES & YES \\
\hline Quarter dummies & YES & YES & YES & YES & YES & YES & YES & YES & YES & YES \\
\hline Size dummies & YES & YES & YES & YES & YES & YES & YES & YES & YES & YES \\
\hline Macro controls & YES & YES & YES & YES & YES & YES & YES & YES & YES & YES \\
\hline
\end{tabular}

Notes: Standard Taylor rule residuals denote residuals obtained from estimating equation 1. Alternative Taylor rule residuals denote residuals obtained from estimating equation 1.1 excluding the output gap. Coefficients expressed as odds ratios with robust standard error in parentheses. ${ }^{* * *}, * * *$ denote significance at the 10,5 and $1 \%$ level. Macro controls include lagged real US and Canadian GDP growth (Q/Q, SAAR) and WTI oil price (USD) growth (Q/Q). 
Table C5: Estimated impact of monetary policy shocks on firms' investment intentions in an ordered logit regression (2001Q2-2016Q1)— Credit conditions sample

$$
\text { Investment }_{i t}=\gamma^{\prime} * X_{i t}+\varphi^{\prime} * \text { macro }_{t-1}+\emptyset_{s} * \sum_{i=0}^{i=s} \text { Monetary_Policy_shock } \text { t }_{t-i}
$$

\begin{tabular}{|c|c|c|c|c|c|c|c|c|c|c|c|}
\hline \multirow[b]{2}{*}{ Sum of lags } & \multicolumn{5}{|c|}{ Contemporaneous Monetary Shocks } & \multicolumn{6}{|c|}{ "Exogenous" Monetary Shocks } \\
\hline & $\operatorname{Lag} 0$ & $\begin{array}{l}\operatorname{Lag} 0 \text { to } \\
\operatorname{Lag} 1\end{array}$ & $\begin{array}{l}\text { Lag } 0 \text { to } \\
\text { Lag } 2\end{array}$ & $\begin{array}{l}\text { Lag } 0 \text { to } \\
\text { Lag } 3\end{array}$ & $\begin{array}{l}\text { Lag } 0 \text { to } \\
\text { Lag } 4\end{array}$ & Lag 5 & $\begin{array}{l}\text { Lag } 5 \text { to } \\
\operatorname{Lag} 6\end{array}$ & & $\begin{array}{ll}\text { Lag } 5 & \text { to } \\
\operatorname{Lag} 10 & \end{array}$ & $\begin{array}{ll}\text { Lag } 5 & \text { to } \\
\operatorname{Lag} 11 & \end{array}$ & $\begin{array}{ll}\text { Lag } 5 & \text { to } \\
\text { Lag } 12 & \end{array}$ \\
\hline & \multicolumn{11}{|c|}{ Odds Ratios } \\
\hline Standard Taylor rule residuals & $\begin{array}{c}1.343^{* * *} \\
(0.135)\end{array}$ & $\begin{array}{l}1.156^{* *} \\
(0.0700)\end{array}$ & $\begin{array}{l}1.103^{* *} \\
(0.0490)\end{array}$ & $\begin{array}{c}1.060 \\
(0.0381)\end{array}$ & $\begin{array}{c}1.043 \\
(0.0321)\end{array}$ & $\begin{array}{c}1.135 \\
(0.106)\end{array}$ & $\begin{array}{c}1.054 \\
(0.0557)\end{array}$ & $\ldots$ & $\begin{array}{c}0.971 \\
(0.0284)\end{array}$ & $\begin{array}{l}0.956^{*} \\
(0.0263)\end{array}$ & $\begin{array}{l}0.945^{* *} \\
(0.0254)\end{array}$ \\
\hline $\begin{array}{l}\text { BOS Indicator: } \\
\text { Alternative Taylor rule residuals }\end{array}$ & $\begin{array}{c}0.982 \\
(0.112)\end{array}$ & $\begin{array}{c}0.986 \\
(0.0693)\end{array}$ & $\begin{array}{c}1.015 \\
(0.0551)\end{array}$ & $\begin{array}{c}1.004 \\
(0.0458)\end{array}$ & $\begin{array}{c}0.983 \\
(0.0394)\end{array}$ & $\begin{array}{c}0.874 \\
(0.103)\end{array}$ & $\begin{array}{c}0.961 \\
(0.0648)\end{array}$ & $\ldots$ & $\begin{array}{l}0.927^{*} \\
(0.0359)\end{array}$ & $\begin{array}{l}0.921^{* *} \\
(0.0344)\end{array}$ & $\begin{array}{l}0.919 * * \\
(0.0339)\end{array}$ \\
\hline $\begin{array}{l}\text { Index of Business Confidence: } \\
\text { Alternative Taylor rule residuals }\end{array}$ & $\begin{array}{c}1.152 \\
(0.124)\end{array}$ & $\begin{array}{c}1.072 \\
(0.0692)\end{array}$ & $\begin{array}{c}1.061 \\
(0.0531)\end{array}$ & $\begin{array}{c}1.032 \\
(0.0428)\end{array}$ & $\begin{array}{c}1.024 \\
(0.0373)\end{array}$ & $\begin{array}{c}1.095 \\
(0.127)\end{array}$ & $\begin{array}{c}1.018 \\
(0.0652)\end{array}$ & $\ldots$ & $\begin{array}{l}0.939 * \\
(0.0329)\end{array}$ & $\begin{array}{l}0.924 * * \\
(0.0314)\end{array}$ & $\begin{array}{l}0.902 * * * \\
(0.0310)\end{array}$ \\
\hline Observations & 4,776 & 4,730 & 4,652 & 4,575 & 5,566 & 4,428 & 4,358 & & 4,051 & 3,972 & 3,896 \\
\hline Degrees of freedom & 18 & 18 & 18 & 18 & 18 & 18 & 18 & & 18 & 18 & 18 \\
\hline Sector dummies & YES & YES & YES & YES & YES & YES & YES & & YES & YES & YES \\
\hline Region dummies & YES & YES & YES & YES & YES & YES & YES & & YES & YES & YES \\
\hline Quarter dummies & YES & YES & YES & YES & YES & YES & YES & & YES & YES & YES \\
\hline Size dummies & YES & YES & YES & YES & YES & YES & YES & & YES & YES & YES \\
\hline Macro controls & YES & YES & YES & YES & YES & YES & YES & & YES & YES & YES \\
\hline
\end{tabular}

Notes: Standard Taylor rule residuals denote residuals obtained from estimating equation 1 . Alternative Taylor rule residuals denote residuals obtained from estimating equation 1.1 excluding the output gap. Coefficients expressed as odds ratios with robust standard error in parentheses. ${ }^{* * *}, * * *$ denote significance at the 10,5 and $1 \%$ level. Macro controls include lagged real US and Canadian GDP growth (Q/Q, SAAR) and WTI oil price (USD) growth (Q/Q). 


\section{Appendix D: “Continuous” Sum of Monetary Policy Shocks Derived from Taylor Rule Estimations-}

\section{From Contemporaneous to More "Exogenous" Shocks}

Table D1: Estimated impact of monetary policy shocks on firms' sales perspectives in an ordered logit regression (2001Q2-2016Q1)"Continuous" sum of monetary policy shocks derived from Taylor rule

$$
\text { Future_Sales }_{i t}=\gamma^{\prime} * X_{i t}+\varphi^{\prime} * \text { macro }_{t-1}+\emptyset_{s} * \sum_{i=0}^{i=s} \text { Monetary_Policy_shock }_{t-i}
$$

From Contemporaneous to More "Exogenous" Monetary Shocks

\begin{tabular}{|c|c|c|c|c|c|c|c|c|c|}
\hline \multirow[b]{2}{*}{ Sum of lags } & & & & & & & & & \\
\hline & Lag 0 & $\begin{array}{l}\text { Lag } 0 \text { to } \\
\operatorname{Lag} 1\end{array}$ & $\begin{array}{l}\text { Lag } 0 \text { to } \\
\operatorname{Lag} 2\end{array}$ & $\begin{array}{l}\text { Lag } 0 \text { to } \\
\text { Lag } 3\end{array}$ & $\begin{array}{l}\text { Lag } 0 \text { to } \\
\operatorname{Lag} 4\end{array}$ & $\begin{array}{l}\text { Lag } 0 \text { to } \\
\text { Lag } 5\end{array}$ & $\begin{array}{l}\text { Lag } 0 \text { to } \\
\text { Lag } 6\end{array}$ & $\begin{array}{l}\text { Lag } 0 \text { to } \\
\operatorname{Lag} 7\end{array}$ & $\begin{array}{l}\operatorname{Lag} 0 \text { to } \\
\operatorname{Lag} 8\end{array}$ \\
\hline & \multicolumn{9}{|c|}{ Odds Ratios } \\
\hline \multirow{2}{*}{ Standard Taylor rule residuals } & $1.288^{* * *}$ & 1.067 & 0.981 & $0.950^{*}$ & $0.936^{* *}$ & $0.923^{* * *}$ & $0.906^{* * *}$ & $0.896 * * *$ & $0.894^{* * *}$ \\
\hline & $(0.114)$ & $(0.0565)$ & $(0.0374)$ & $(0.0291)$ & $(0.0245)$ & $(0.0221)$ & $(0.0197)$ & $(0.0183)$ & $(0.0174)$ \\
\hline BOS Indicator: & $1.307^{* * *}$ & 1.089 & 1.027 & 0.995 & 0.958 & $0.938^{* *}$ & $0.909^{* * *}$ & $0.885^{* * *}$ & $0.874 * * *$ \\
\hline Alternative Taylor rule residuals & $(0.133)$ & $(0.0683)$ & $(0.0488)$ & $(0.0397)$ & $(0.0338)$ & $(0.0297)$ & $(0.0267)$ & $(0.0251)$ & $(0.0245)$ \\
\hline \multirow{2}{*}{$\begin{array}{l}\text { Index of Business Confidence: } \\
\text { Alternative Taylor rule residuals }\end{array}$} & 1.156 & 0.999 & 0.958 & 0.954 & 0.953 & $0.947^{*}$ & $0.918^{* * *}$ & $0.898^{* * *}$ & $0.880^{* * *}$ \\
\hline & $(0.110)$ & $(0.0566)$ & $(0.0416)$ & $(0.0341)$ & $(0.0298)$ & $(0.0273)$ & $(0.0251)$ & $(0.0240)$ & $(0.0236)$ \\
\hline Observations & 5,974 & 5,910 & 5,811 & 5,717 & 5,618 & 5,523 & 5,425 & 5,325 & 5,225 \\
\hline Degrees of freedom & 18 & 18 & 18 & 18 & 18 & 18 & 18 & 18 & 18 \\
\hline Sector dummies & YES & YES & YES & YES & YES & YES & YES & YES & YES \\
\hline Region dummies & YES & YES & YES & YES & YES & YES & YES & YES & YES \\
\hline Quarter dummies & YES & YES & YES & YES & YES & YES & YES & YES & YES \\
\hline Size dummies & YES & YES & YES & YES & YES & YES & YES & YES & YES \\
\hline Macro controls & YES & YES & YES & YES & YES & YES & YES & YES & YES \\
\hline
\end{tabular}

Notes: All Taylor rule estimations are done in real time à la Koenig et al. (2003). Standard Taylor rule residuals denote residuals obtained from estimating equation 1. Alternative Taylor rule residuals denote residuals obtained from estimating equation 1.1 excluding the output gap. Coefficients expressed as odds ratios with robust standard error in parentheses. ${ }^{* * *}, * * *$ denote significance at the 10,5 and $1 \%$ level. Macro controls include lagged real US and Canadian GDP growth (Q/Q, SAAR) and WTI oil price (USD) growth (Q/Q). 
Table D2: Estimated impact of monetary policy shocks on firms' future sales indicators in an ordered logit regression (2001Q2-2016Q1)"Continuous" sum of monetary policy shocks derived from Taylor rule

$$
\text { Future_Sales_Indicators }_{i t}=\gamma^{\prime} * X_{i t}+\varphi^{\prime} * \text { macro }_{t-1}+\emptyset_{s} * \sum_{i=0}^{i=s} \text { Monetary_Policy_shock }_{t-i}
$$

From Contemporaneous to More "Exogenous" Monetary Shocks

\begin{tabular}{|c|c|c|c|c|c|c|c|c|c|}
\hline \multirow{3}{*}{ Sum of lags } & \\
\hline & Lag 0 & $\begin{array}{l}\text { Lag } 0 \text { to } \\
\text { Lag } 1\end{array}$ & $\begin{array}{l}\text { Lag } 0 \text { to } \\
\operatorname{Lag} 2\end{array}$ & $\begin{array}{l}\text { Lag } 0 \text { to } \\
\text { Lag } 3\end{array}$ & $\begin{array}{l}\text { Lag } 0 \text { to } \\
\text { Lag } 4\end{array}$ & $\begin{array}{l}\text { Lag } 0 \text { to } \\
\text { Lag } 5\end{array}$ & $\begin{array}{l}\text { Lag } 0 \text { to } \\
\operatorname{Lag} 6\end{array}$ & $\begin{array}{l}\text { Lag } 0 \text { to } \\
\operatorname{Lag} 7\end{array}$ & $\begin{array}{l}\text { Lag } 0 \text { to } \\
\text { Lag } 8\end{array}$ \\
\hline & \multicolumn{9}{|c|}{ Odds Ratios } \\
\hline Standard Taylor rule residuals & $\begin{array}{c}1.388 * * * \\
(0.141)\end{array}$ & $\begin{array}{l}1.186 * * * \\
(0.0727)\end{array}$ & $\begin{array}{l}1.139 * * * \\
(0.0518)\end{array}$ & $\begin{array}{l}1.120 * * * \\
(0.0404)\end{array}$ & $\begin{array}{l}1.085 * * * \\
(0.0326)\end{array}$ & $\begin{array}{c}1.053^{*} \\
(0.0275)\end{array}$ & $\begin{array}{c}1.024 \\
(0.0242)\end{array}$ & $\begin{array}{c}1.006 \\
(0.0220)\end{array}$ & $\begin{array}{c}0.991 \\
(0.0202)\end{array}$ \\
\hline $\begin{array}{l}\text { BOS Indicator: } \\
\text { Alternative Taylor rule residuals }\end{array}$ & $\begin{array}{c}1.181 \\
(0.157)\end{array}$ & $\begin{array}{c}1.095 \\
(0.0831)\end{array}$ & $\begin{array}{c}1.079 \\
(0.0591)\end{array}$ & $\begin{array}{c}1.070 \\
(0.0474)\end{array}$ & $\begin{array}{c}1.032 \\
(0.0399)\end{array}$ & $\begin{array}{c}1.004 \\
(0.0339)\end{array}$ & $\begin{array}{c}0.985 \\
(0.0300)\end{array}$ & $\begin{array}{c}0.970 \\
(0.0281)\end{array}$ & $\begin{array}{c}0.949 * \\
(0.0271)\end{array}$ \\
\hline $\begin{array}{l}\text { Index of Business Confidence: } \\
\text { Alternative Taylor rule residuals }\end{array}$ & $\begin{array}{l}1.314 * * \\
(0.150)\end{array}$ & $\begin{array}{l}1.186 * * \\
(0.0806)\end{array}$ & $\begin{array}{c}1.148 * * * \\
(0.0594)\end{array}$ & $\begin{array}{c}1.129 * * * \\
(0.0463)\end{array}$ & $\begin{array}{c}1.095 * * * \\
(0.0384)\end{array}$ & $\begin{array}{l}1.068 * * \\
(0.0337)\end{array}$ & $\begin{array}{c}1.041 \\
(0.0308)\end{array}$ & $\begin{array}{c}1.020 \\
(0.0290)\end{array}$ & $\begin{array}{c}0.998 \\
(0.0280)\end{array}$ \\
\hline Observations & 5,053 & 5,053 & 5,053 & 5,053 & 5,053 & 5,053 & 5,053 & 5,053 & 5,053 \\
\hline Degrees of freedom & 18 & 18 & 18 & 18 & 18 & 18 & 18 & 18 & 18 \\
\hline Sector dummies & YES & YES & YES & YES & YES & YES & YES & YES & YES \\
\hline Region dummies & YES & YES & YES & YES & YES & YES & YES & YES & YES \\
\hline Quarter dummies & YES & YES & YES & YES & YES & YES & YES & YES & YES \\
\hline Size dummies & YES & YES & YES & YES & YES & YES & YES & YES & YES \\
\hline Macro controls & YES & YES & YES & YES & YES & YES & YES & YES & YES \\
\hline
\end{tabular}

Notes: All Taylor rule estimations are done in real time à la Koenig et al. (2003). Standard Taylor rule residuals denote residuals obtained from estimating equation 1. Alternative Taylor rule residuals denote residuals obtained from estimating equation 1.1 excluding the output gap. Coefficients expressed as odds ratios with robust standard error in parentheses. ****** denote significance at the 10,5 and $1 \%$ level. Macro controls include lagged real US and Canadian GDP growth (Q/Q, SAAR) and WTI oil price (USD) growth (Q/Q). 
Table D3: Estimated impact of monetary policy shocks on firms' credit conditions in an ordered logit regression (2001Q2-2016Q1)"Continuous" sum of monetary policy shocks derived from Taylor rule

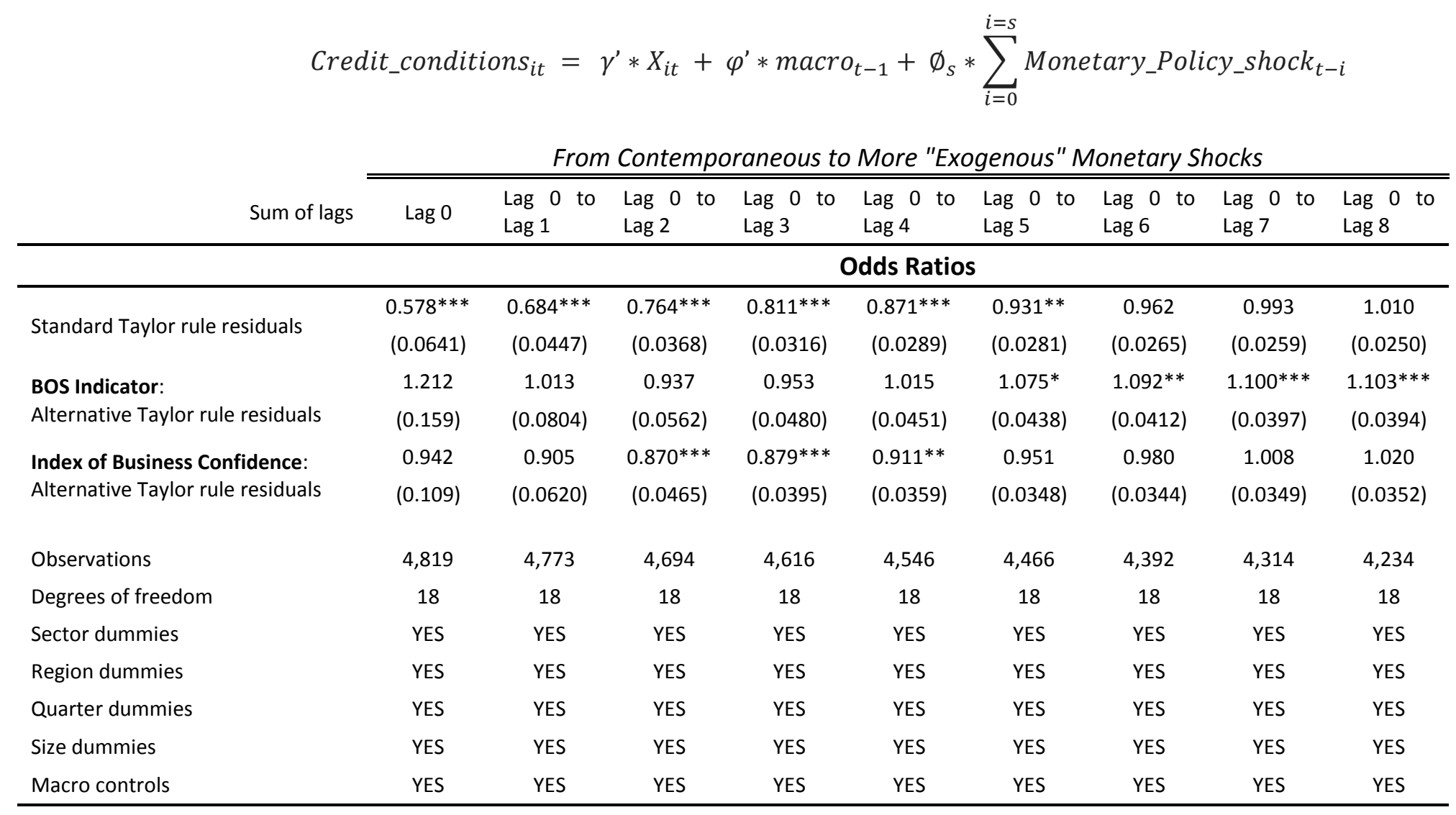

Notes: Standard Taylor rule residuals denote residuals obtained from estimating equation 1. Alternative Taylor rule residuals denote residuals obtained from estimating equation 1.1 excluding the output gap. Coefficients expressed as odds ratios with robust standard error in parentheses. ${ }^{*}, * *, * * *$ denote significance at the 10, 5 and $1 \%$ level. Macro controls include lagged real US and Canadian GDP growth (Q/Q, SAAR) and WTI oil price (USD) growth (Q/Q). 
Table D4: Estimated impact of monetary policy shocks on firms' output price perspectives in an ordered logit regression (2001Q2-2016Q1)"Continuous" sum of monetary policy shocks derived from Taylor rule

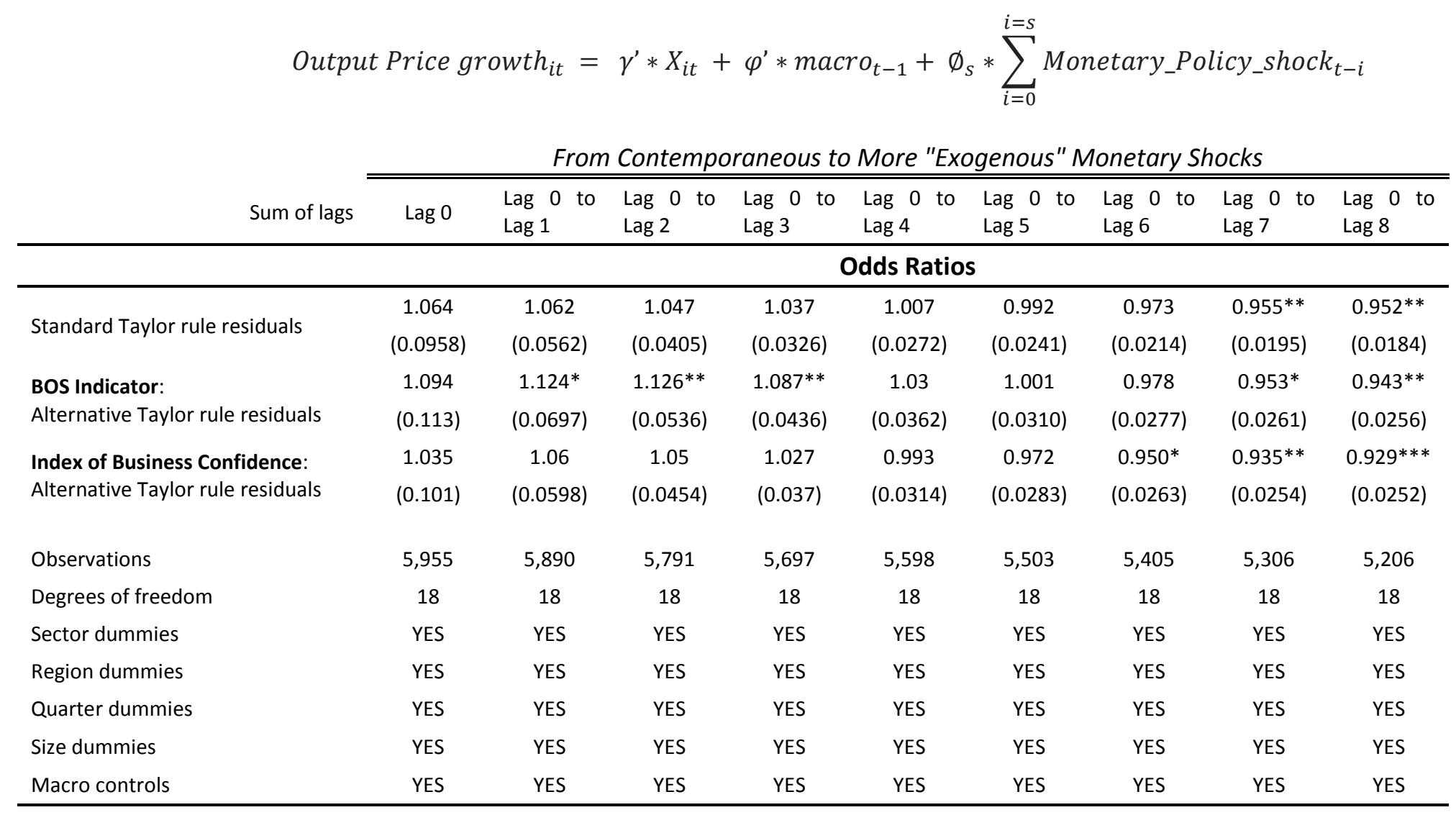

Notes: Standard Taylor rule residuals denote residuals obtained from estimating equation 1. Alternative Taylor rule residuals denote residuals obtained from estimating equation 1.1 excluding the output gap. Coefficients expressed as odds ratios with robust standard error in parentheses. ${ }^{*}, * *, * * *$ denote significance at the 10, 5 and $1 \%$ level. Macro controls include lagged real US and Canadian GDP growth (Q/Q, SAAR) and WTI oil price (USD) growth (Q/Q). 
Table D5: Estimated impact of monetary policy shocks on firms' wage growth perspectives in an ordered logit regression (2001Q2-2016Q1)— "Continuous" sum of monetary policy shocks derived from Taylor rule

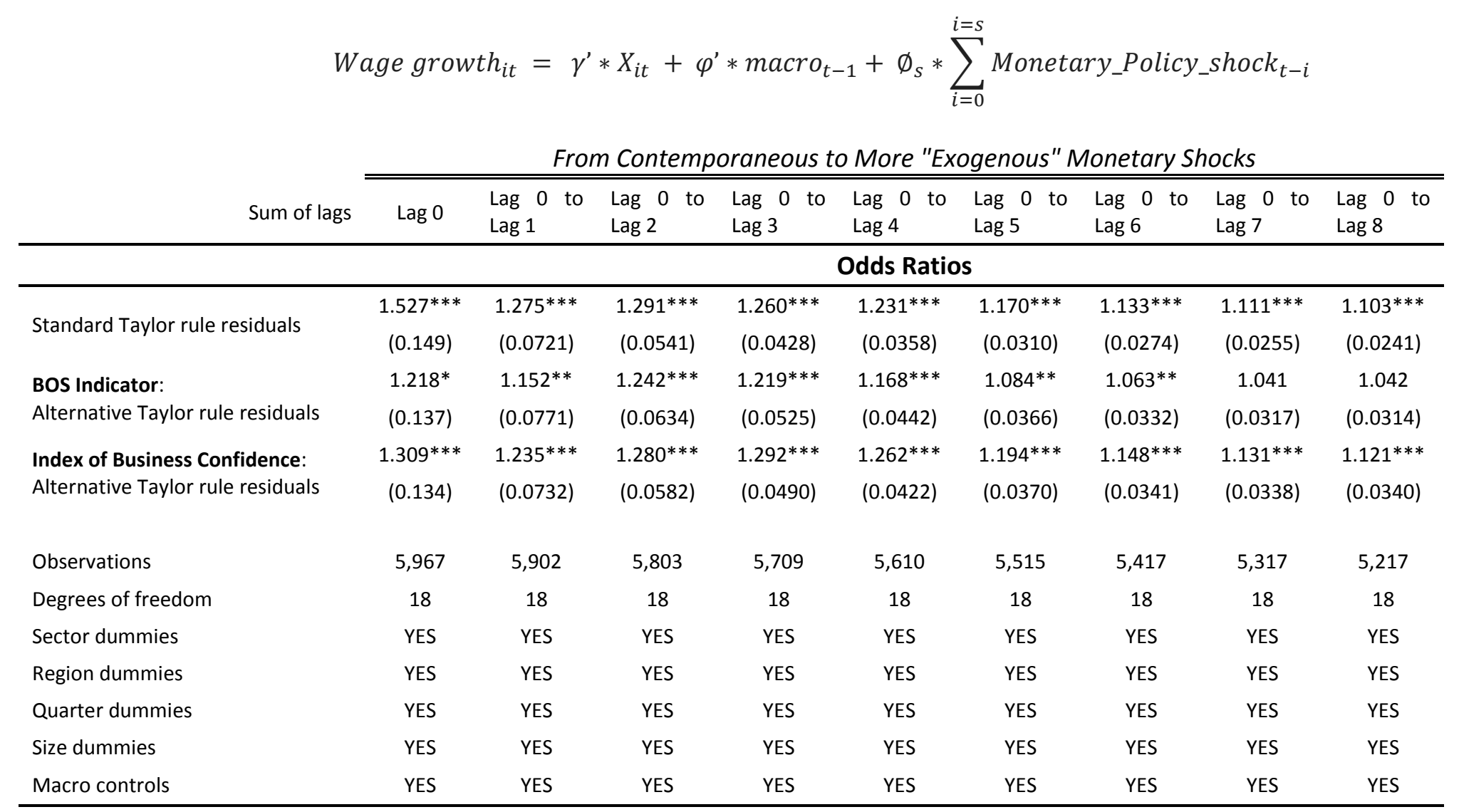

Notes: Standard Taylor rule residuals denote residuals obtained from estimating equation 1. Alternative Taylor rule residuals denote residuals obtained from estimating equation 1.1 excluding the output gap. Coefficients expressed as odds ratios with robust standard error in parentheses. $*, * *, * * *$ denote significance at the 10, 5 and 1\% level. Macro controls include lagged real US and Canadian GDP growth (Q/Q, SAAR) and WTI oil price (USD) growth (Q/Q). 
Appendix E: Responses of BOS Variables Expressed as Balances of Opinion to Alternative Monetary Policy Shock Controlling for Lagged Real US GDP Growth (SAAR) and WTI Oil Price (USD) Growth (Q/Q)

Chart E1: Accumulated response of future sales (balance of opinion) to alternative monetary policy shock-Index of Business Confidence replaces output gap in the monetary feedback rule

Accumulated Response to Cholesky One S.D. Innovations \pm 2 S.E.

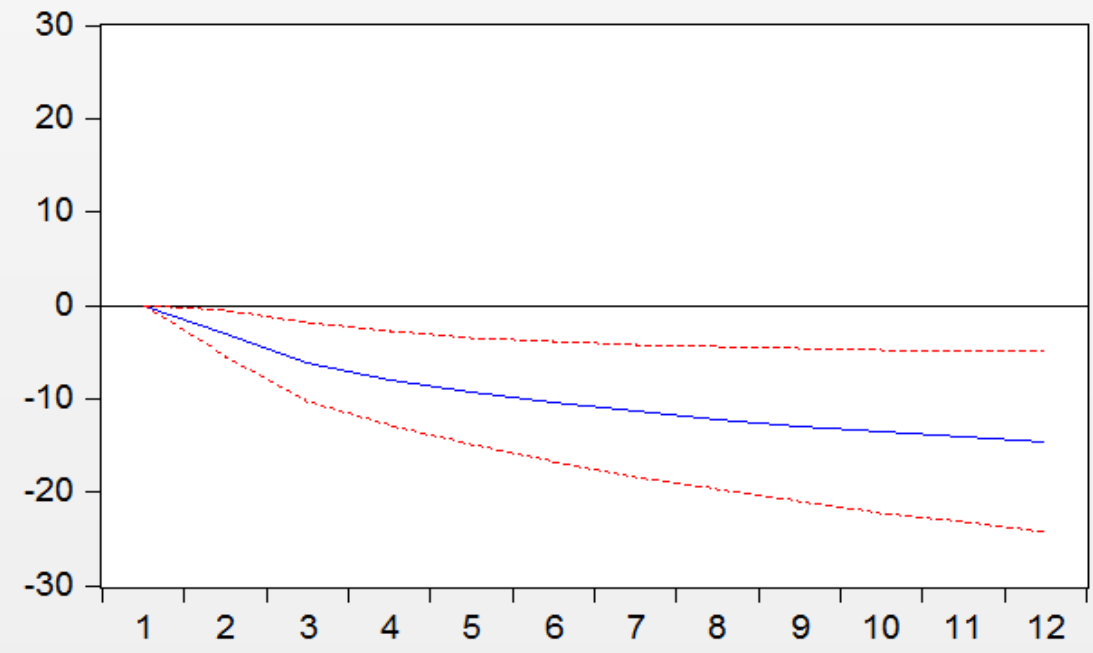

Chart E2: Accumulated response of indicators of future sales (balance of opinion) to alternative monetary policy shock-Index of Business Confidence replaces output gap in the monetary feedback rule

Accumulated Response to Cholesky One S.D. Innovations \pm 2 S.E.

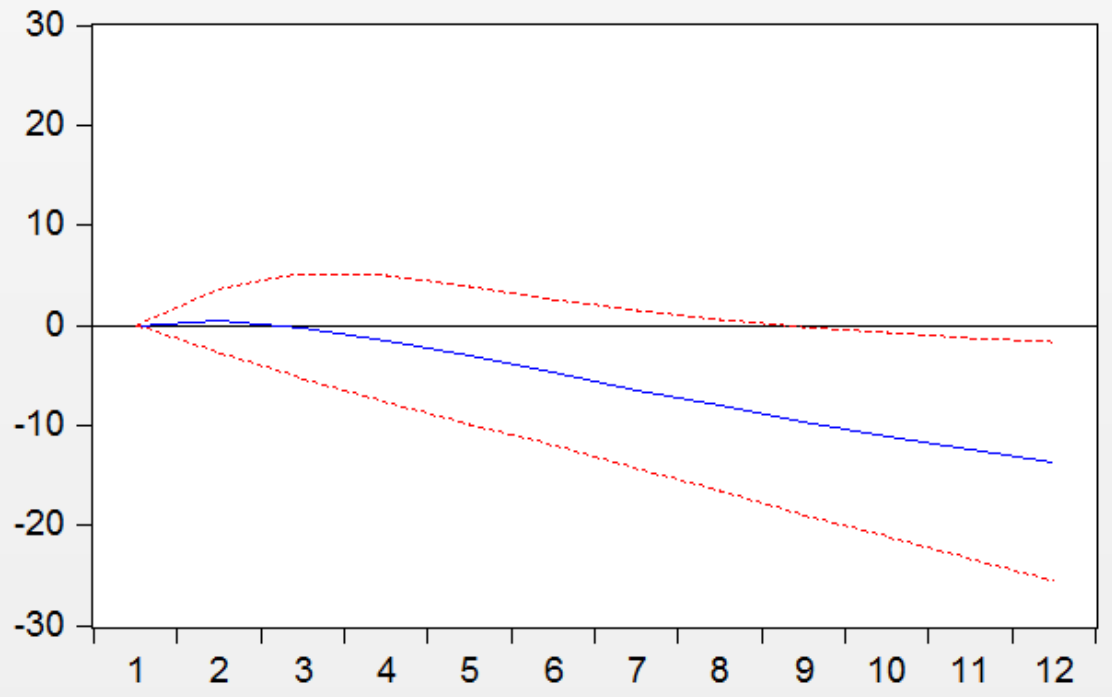


Chart E3: Accumulated response of credit conditions (balance of opinion) to alternative monetary policy shock-Index of Business Confidence replaces output gap in the monetary feedback rule

Accumulated Response to Cholesky One S.D. Innovations \pm 2 S.E.

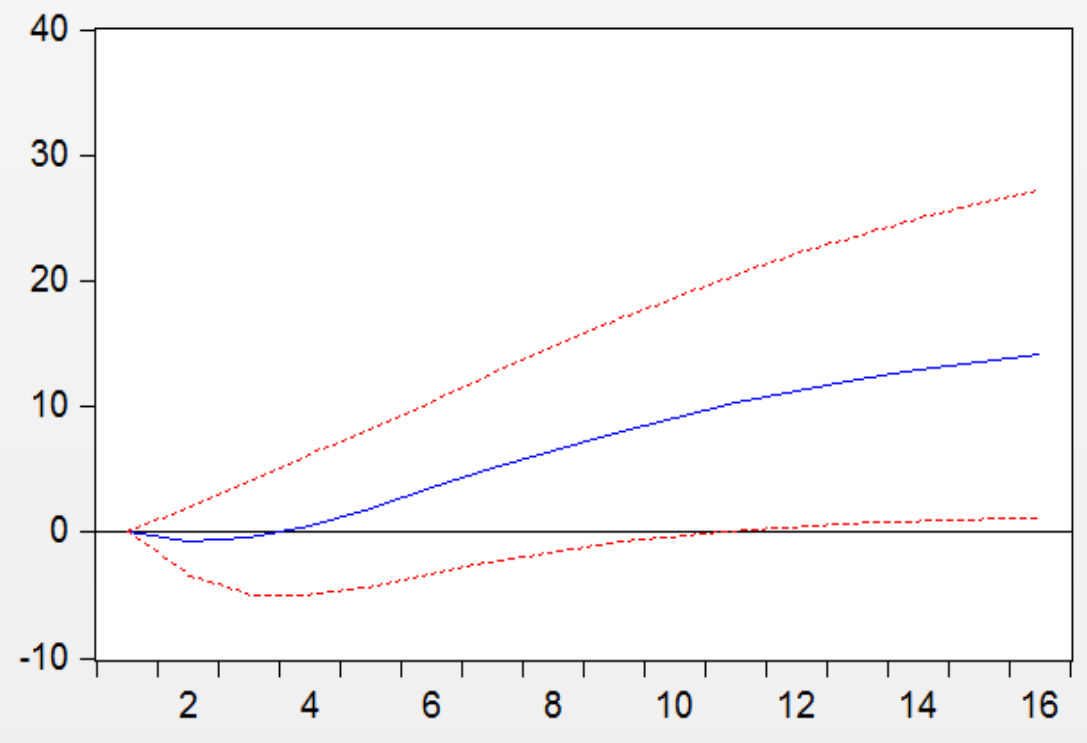

Chart E4: Accumulated response of output price growth (balance of opinion) to alternative monetary policy shock-Index of Business Confidence replaces output gap in the monetary feedback rule

Accumulated Response to Cholesky One S.D. Innovations \pm 2 S.E.

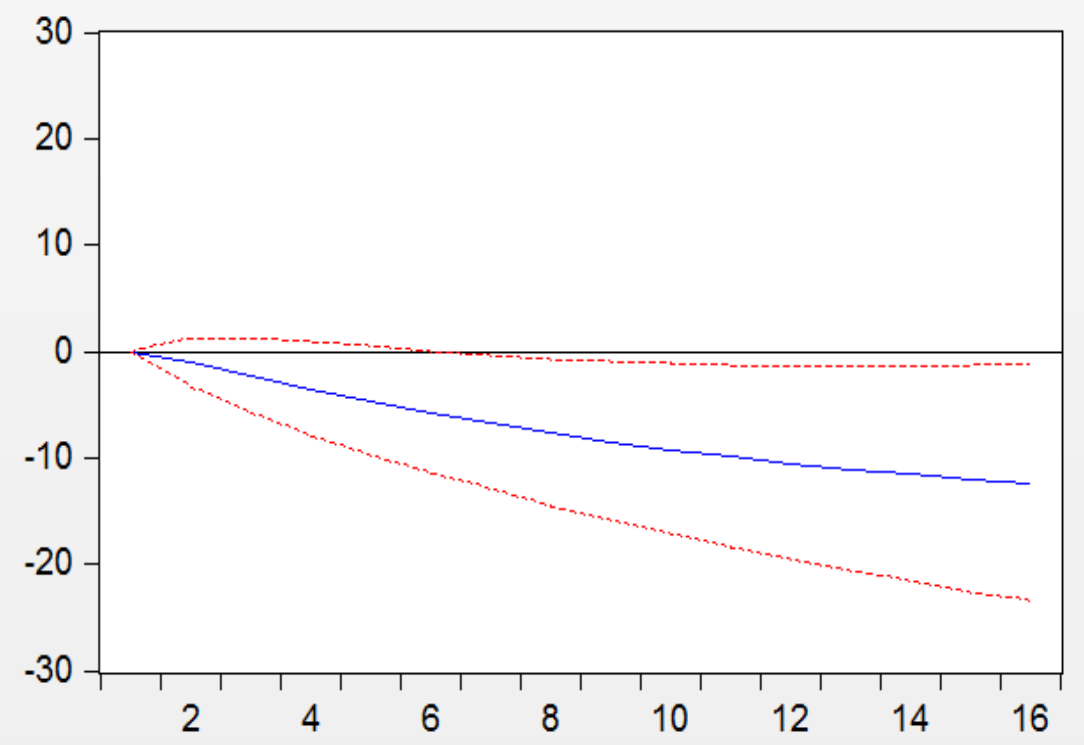


Chart E5: Accumulated response of wage growth (balance of opinion) to alternative monetary policy shock-Index of Business Confidence replaces output gap in the monetary feedback rule

Accumulated Response to Cholesky One S.D. Innovations \pm 2 S.E.

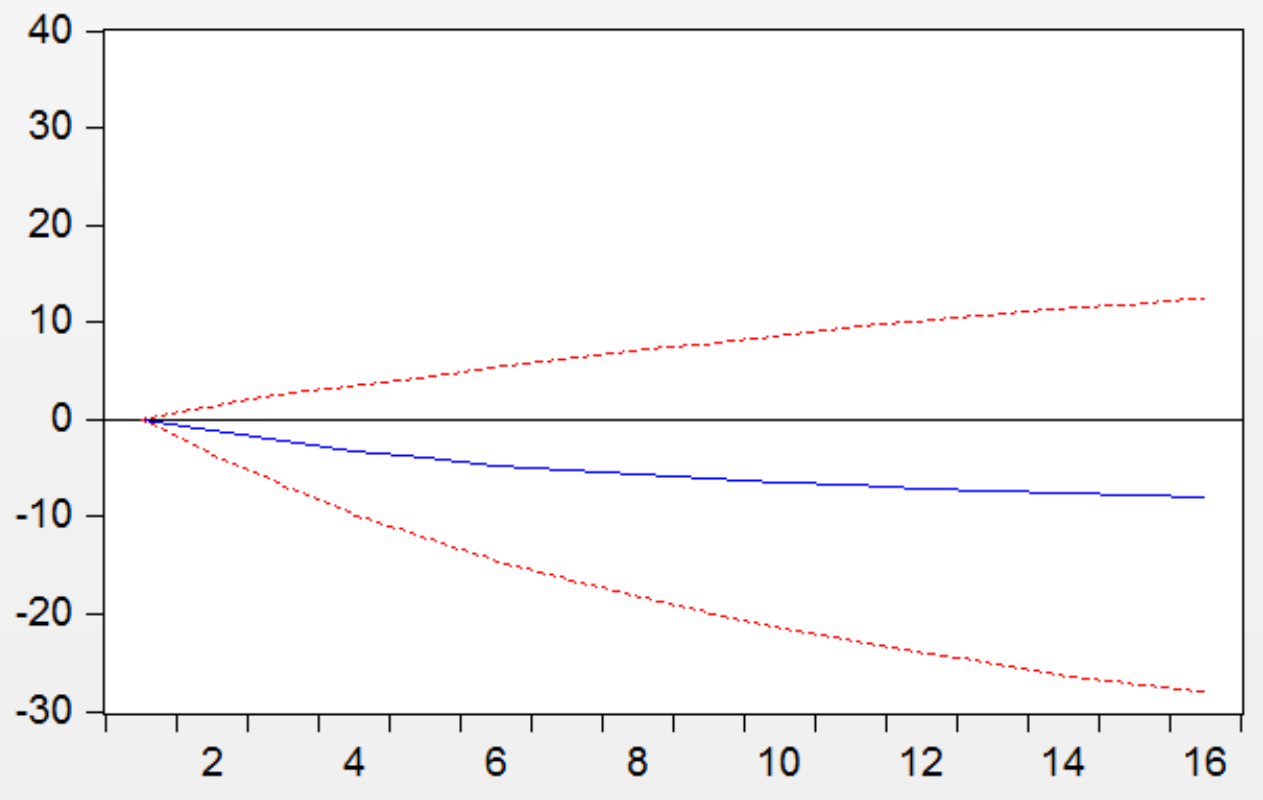

Chart E6: Accumulated response of investment intentions (balance of opinion) to alternative monetary policy shock-Index of Business Confidence replaces output gap in the monetary feedback rule

Accumulated Response to Cholesky One S.D. Innovations \pm 2 S.E.

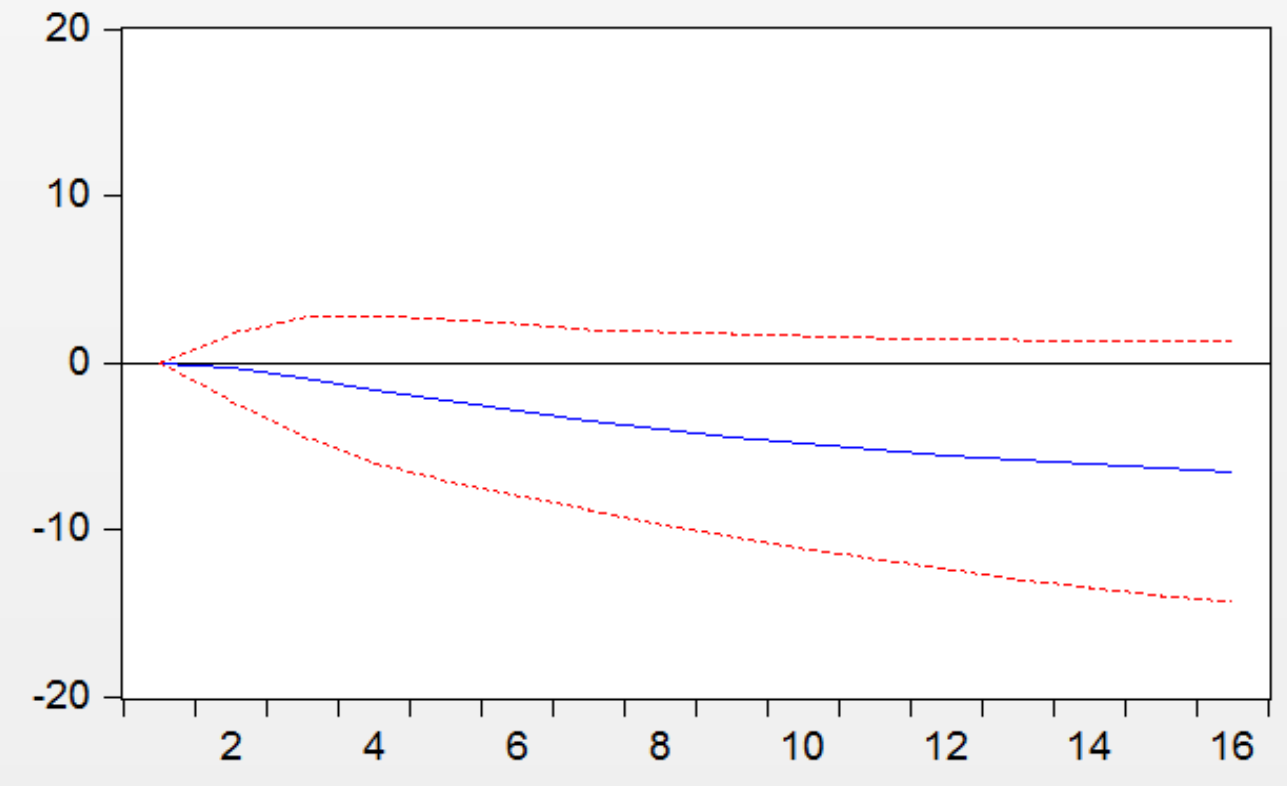

